
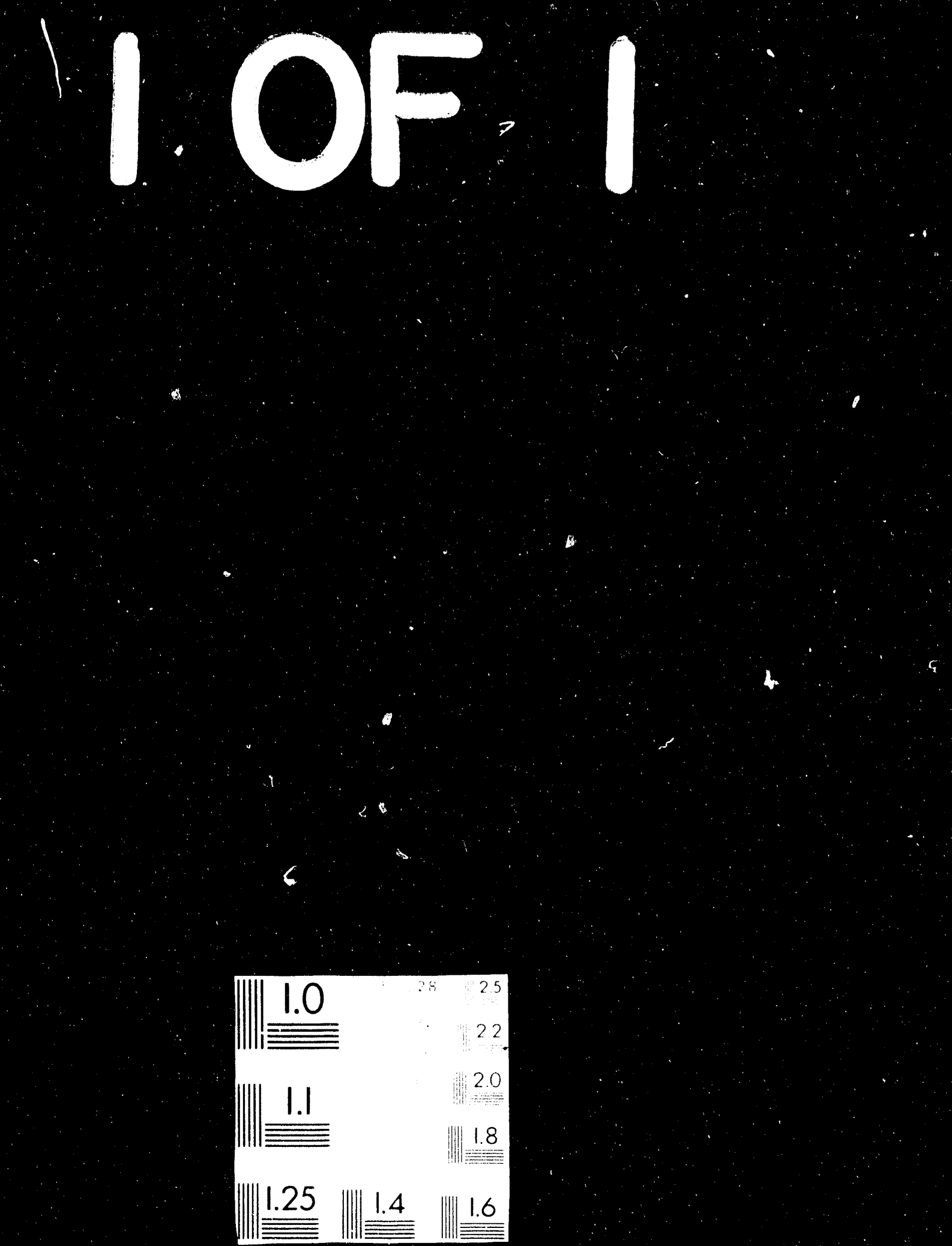

bathtub mode, the container must fill before outflow starts. This could take hundreds or thousands of years. In the flowthrough mode, the water would 


\title{
Post-Closure Performance Assessment of Waste Packages for the \\ Yucca Mountain Project
}

\author{
W. J. O'Connell \\ T. S. Ueng \\ L. C. Lewis
}

Lawrence Livermore National Laboratory

Publication Date: October 1993

This is an informal report intended primarily for intemal or limited extemal distribution. The opinions and conclusions stated are those of the author and may or may not be those of the Laboratory.

Work performed under the auspices of the U.S. Department of Energy by the - Lawrence Livermore National Laboratory under Contract W-7405-Eng-48. 


\section{DISCLAIMER}

This document was prepared as an account of work sponsored by an agency of the United States Government. Neither the United States Government nor the University of Califoraia nor any of their employees, makes any warranty, express or implied, or assumes any legal liability or responsibility for the accuracy, completeness, or usefulness of any information, apparatus, product, or process disclosed, or represents that its use would not infringe privately owned rights. Reference herein to any specific commercial products, process, or service by trade name, trademark, manufacturer, or otherwise, does not necessarily constitute or imply its endorsement, recommendation, or favoring by the United States Government or the University of Califormia. The views and opinions of authors expressed herein do not necessarily state or reflect those of the United States Government or the University of Californiz, and shall not be used for advertising or product endorsement purposes.

This report has been reproduced directly from the best available copy.

\section{A vailable to DOE and DOE contractors from the Ofrice of Scientific and Technical Information P.O. Box 62, Oak Ridge, TN 37831}

Prices available from (615) 576-8401, FTS 626-8401

Available to the public from the National Technical Information Service

US. Department of Commerce 5285 Port Royal Rd. Springfield, VA 22161

Prepared by Yucca Mountain Site Characterization Project (YMP) participants as parc of the Civilian Radioactive Waste Management Program. The YMP is managed by the Yucca Mountain Site Characterization Project Office of the U.S. Department of Energy, Las Vegas, Nevada. 


\section{POST-CLOSURE PERFORMANCE ASSESSMENT OF WASTE PACKAGES FOR THE YUCCA MOUNTAIN PROJECT}

\section{INTRODUCTION}

This report details a system model of some core features of the performance of waste packages for the permanent disposal of spent nuclear fuel. The model is realized in the prototype computer program PANDORA-1.1.

The PANDORA system model links processes leading to possible release of radionuclides from the waste package. The process models are summaries based on data or on more detailed models. We plan to develop our performance assessment model in several generations. The current version, PANDORA-1.1, models the last steps in the sequence of processes leading to release. Earlier steps, now taken as inputs, can be modeled in later versions of PANDORA.

A potential repository site at Yucca Mountain, Nevada, is being evaluated for its suitability for permanent disposal of high level nuclear waste and spent nuclear fuel. This work is being carried out by the Department of Energy's (DOE) Yucca Mountain Site Characterization Project (YMP). Lawrence Livermore National Laboratory (LLNL) has been developing the near-field environment characterization, design basis, and performance assessment for the waste packages. The PANDORA submodels are being developed for processes and conditions specific to this potential repository site, notably the comparatively dry location in an arid area and well above the groundwater table, and the rock medium of porous partially welded tuff.

The waste package is a key element of the engineered barrier system (EBS). The EBS is the aggregate of all the human-made components of the waste repository, including the waste form itself, the waste package, overpacking materials if used, a borehole air gap if used, borehole liners, and repository seals.

A mined geologic disposal system consists of the natural geologic site, the nearfield environment, and the EBS. The near-field environment is a part or the natural system which is unavoidably disturbed in some respects by repository 
construction and waste emplacement, and may be beneficially altered, for example by controlling the waste emplacement to achieve a selected degree of heating.

EPA and NRC regulations set performance requirements on the overall system and on the EBS (and on the natural geologic system, which we do not discuss separately here). The EPA in 40 CFR 191 (presently in process of revision) sets performance requirements on the total system in terms of protecting the humanaccessible environment for the goal of protecting human health. The NRC requirements in 10 CFR 60.113 are for (a) substantially complete containment of the radioactive materials inside the waste packages for a period of up to 300 to 1000 years after repository closure, and (b) limits on the release rates of radionuclides from the EBS over a longer time period. The latter limits are defined more precisely in Section 3 below.

PANDORA-1.1 calculates the release rate of radionuclides over time for a single waste package. The release rates of waste packages with their different local conditions may then be summed. The summed release rate of all the waste packages in the potential repository can be compared to the NRC's release rate requirement in $10 \mathrm{CFR} 60.113$. The summed release rate from all the waste packages also serves as the source term in a calculation of transport through the natural system to the accessible environment for comparison with the EPA performance requirement. PANDORA-1.1, with subsequent summation of releases over different waste packages, has been used to provide source terms [Apted, et al., 1990, 1991] for such total system performance assessments [Barnard, 1991].

The PANDORA-1.1 model has been used for the source term in a fracture-flow performance analysis [Gauthier, et al., 1992]. PANDORA-1.1 has also been used as guidance in a simplified source term model transmitted from LLNL to Sandia National Laboratories and reported by Barnard, et al. [1992].

PANDORA-1.1 treats the major physical components of the spent fuel waste form and all of the radionuclides in spent fuel. PANDORA-1.1 treats the radionuclide mobilization and transport to the outside of the waste package, which are the last steps leading to release from the waste package. Earlier steps, 
such as the hydrologic conditions outside the waste package and the breach of the container, are taken as inputs in PANDORA-1.1.

For most radioactive elements, the mobilization and release require water as a dissolving medium and a transport medium. Water contact with the waste package may or may not occur, but where it does, it can conceivably be by contact with porous rock, allowing a surface film contact and diffusion, or by local seeping or dripping onto the waste package. The diffusive contact mode has been evaluated in separate reports [Pigford, et al., 1990; Ueng and O'Connell, 1992]. PANDORA-1.1 evaluates the consequences of a dripping or trickling water contact. Even within this limited scope, the processes can be quite complex and interacting. The intent for PANDORA is to develop a simple system model by developing submodels which are either summaries or bounding simplifications of more detailed process models.

A small fraction of the radioactive waste elements can exist as gases. By 200 years after the spent fuel is out of the reactor, less than $0.1 \%$ of the inventory is in potentially gaseous elements; most of that is C-14 which can form carbon dioxide. Only a small fraction of the potentially gaseous inventory can be mobilized if no water is present. PANDORA-1.1 addresses these situations.

\section{Qverview of PANDORA-1,1}

The waste package features and processes treated in PANDORA-1.1 are summarized in Table 1. The waste locations and chemical types are discussed in Section 2.2. The mobilization and transport processes are introduced in Section 2.3. The relation of performance assessment to design is discussed in Section 3.

The program, and the detailed presentation of Section 4, are organized at the top level by the two processes of mobilization (called the alteration model because that is the major process for mobilization) and transport. At the next level ai the contact modes of air, bathtub, and flowthrough alternatives. The air-mediated process also takes place in parallel if there is water contact. At the third level are the radionuclide types of gas, high-solubility (mobilization being matrix alteration rate limited) and low-solubility (mobilization being solubility limitcd). For each type, the locations and quantities for that type are accounted for. 
Table 1. Features and Processes Treated in PANDORA-1.1

\begin{tabular}{|c|c|}
\hline Locations of radionuclides ${ }^{(a)}$ & $\begin{array}{l}\text { Surface of cladding } \\
\text { Fuel/cladding gap } \\
\text { Spent fuel pellet matrix }\end{array}$ \\
\hline Chemical Types ${ }^{(b)}$ & $\begin{array}{l}\text { Gas } \\
\text { High solubility } \\
\text { Low solubility } \\
\text { Secular equilibrium }\end{array}$ \\
\hline Mobilization Medium(c) & $\begin{array}{l}\text { Air - breach of container } \\
\text { Water contact - bathtub } \\
\text { Water contact - flowthrough }\end{array}$ \\
\hline Transport Process ${ }^{(c)}$ & $\begin{array}{l}\text { Gaseous diffusion } \\
\text { Advection - bathtub } \\
\text { Advection - flowthrough }\end{array}$ \\
\hline
\end{tabular}

Note: (a) Cladding and hardware solids will be treated in a future version.

(b) The program determines whether a given solubility is low or high.

(c) Diffusive contact is treated separately by Ueng and O'Connell [1992].

Many of the features and processes of the waste packages and their immediate environments have been identified as needed inputs and hence potentially important to performance. The topical areas of the inputs for waste form alteration and waste release are:
1. Container breach,
2. Near-field hydrology,
3. In-package hydrology,
4. Waste form characteristics, and
5. Geochemistry/waste form interaction.

The inain features that comprise the substance of the calculation are: 
1. Availability for release: the interplay of the in-package hydrology and the waste form properties and alteration.

2. Release: the interplay of availability, solubility, inventory, and release processes.

Other features included in the PANDORA-1.1 calculation are:

1. In-package hydrology,

2. Timing of releases and spreading of releases over time,

3. Treating the different locations of radionuclides in spent fuel,

4. Tracking of inventories due to buildup and decay,

5. Exhaustion of inventories by transport and decay, and

6. Ratio of release rates to NRC limits.

Careful attention was given to making the program robust over a wide range of parameter values. The program covers ranges of low to high water flux, low to high matrix chemical alteration rates, and low to high solubilities. The average groundwater flux is expected to be low, but in some scenarios, the water flux could be episodic flux in a few fractures, and hence one or two waste packages could experience high water flux [Buscheck et al., 1991].

We $\mathrm{p} \eta \eta$ to develop our performance evaluation model and program in several generations. The present first-generation model focuses on the release rates of radionuclides into the rock. This first model has simple submodels or simple inputs for many of the important processes affecting the waste package and couples them so as to track their interactions over time and to evaluate the performance of the waste package. Our purpose is to acquire (l) first approximation results for guidance in design and in site characterization scoping and (2) a guide to the development of later generations of the program. Later generations will be more detailed and accurate and will incorporate new information developed by the YMP testing series and any new features needed to model later reference designs of waste packages. A second series of our computer programs will examine the reliability of the waste package performance [O'Connell et al., 1989; O'Connell, 1990]. 
PANDORA-1.1 is one of the first series of programs which are deterministic in their character; they can serve as a core or a guide for the probabilistic reliability programs. Attempts were originally made to model various processes affecting the waste package performance as far as possible and then to couple ihese models through an explicit set of data transfers [O'Connell and Drach, 1986]. Due to the limited knowledge base and mechanistic understanding of most processes and the difficulties in acquiring referenced data at this time, it was decided that the current version of the PANDORA model will focus on the radionuclide releases from a single spent fuel waste package by the processes of waste form alteration and transport with groundwater flow.

\section{WASTE PACKAGES AND PROCESSES AFFECTING WASTE PACKAGE PERFORMANCE}

\subsection{Waste Forms and Waste Packages}

There are mainly two types of waste forms: (1) spent nuclear fuel and (2) highlevel waste solidified in a glass matrix. The spent fuel rods may be in assemblies as removed from the reactor, or they may be consolidated into a smaller volume. The current version of PANDORA model only evaluates the performance of waste packages with spent nuclear fuel.

At present, no single package design has been selected. Figures 1 shows an example of the conceptual design waste packages for spent fuel [USDOE, 1988] emplaced in vertical borehole. Alternate designs under consideration [HarrisonGiesler and Morissette, 1991; Short et al., 1991] include different dimensions and packing, different container metals or alloys, multiple-barrier containers, and different emplacement geometries. Figure 2 shows a concept for drift emplacement horizontally with large thick-walled containers.

The dimensions and contents of the waste package are input parameters in PANDORA-1.1. Container breach is considered to be the condition when all of the barriers are breached, allowing are access to the spent fuel rods; this is represented by an input breach time. The near-field hydrology and in-package hydrology', which may depend on the package dimensions, orientation, and emplacement, are also covered by input parameters. 


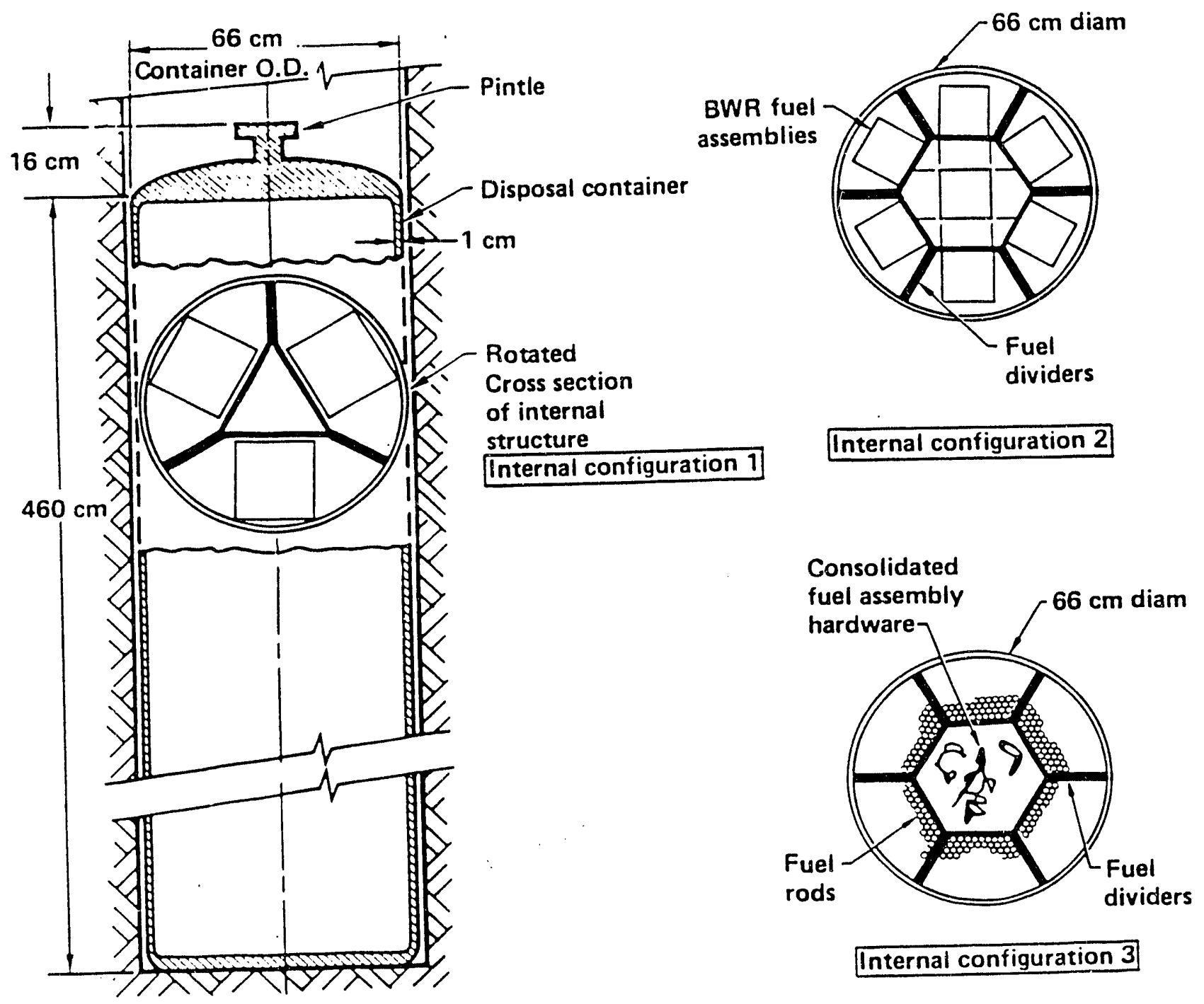

Figure 1. Conceptual Design Spent Fuel Waste Package in a Borehole 


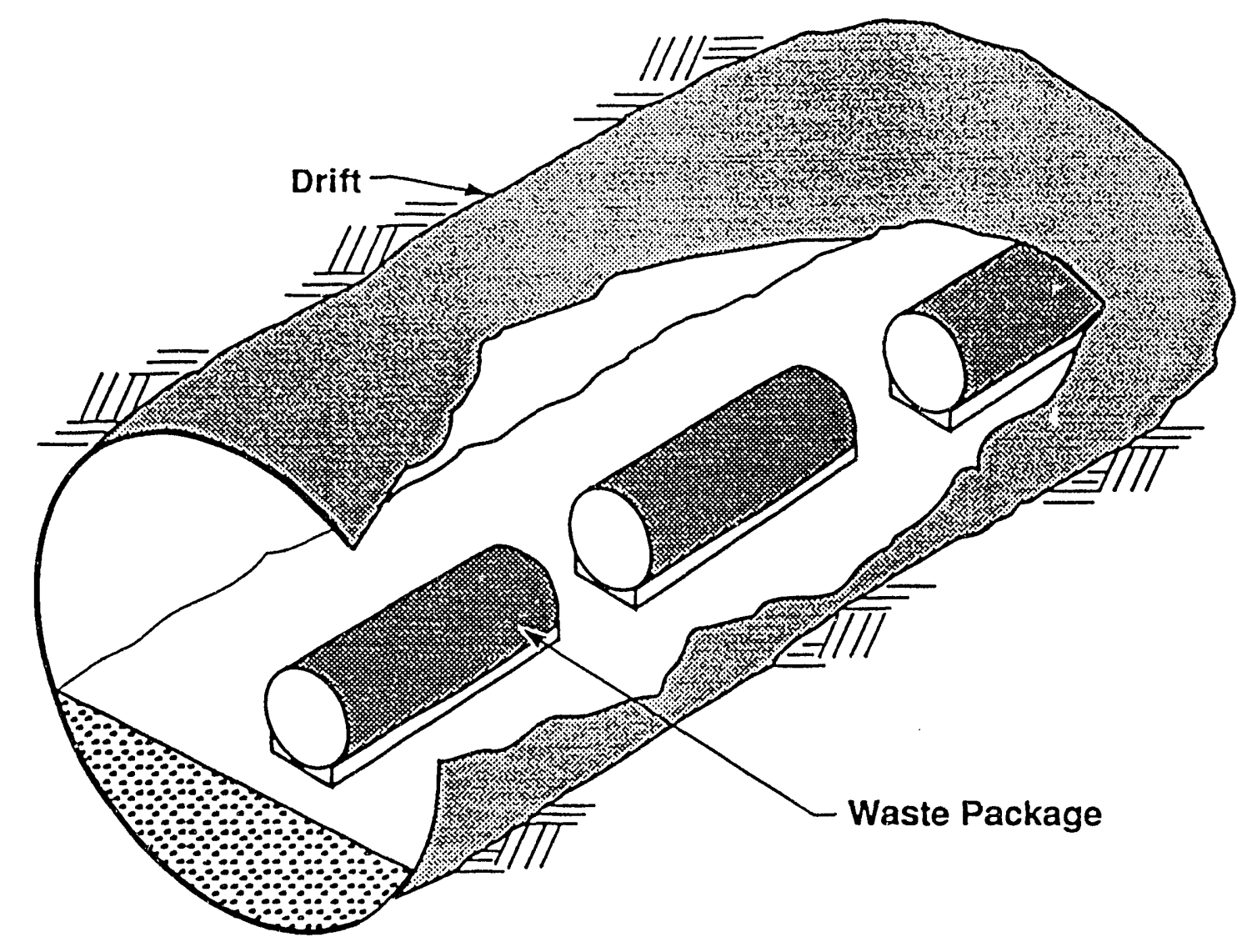

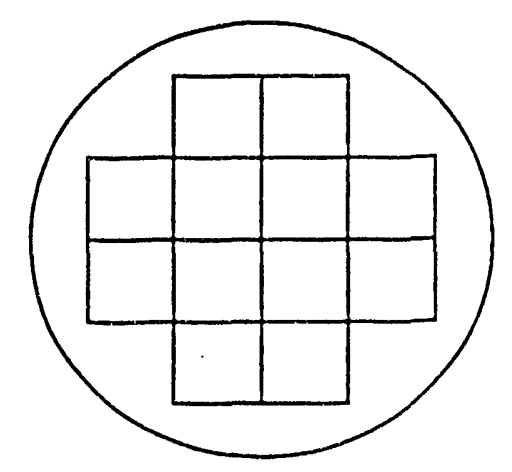

12 PWR Assemblies

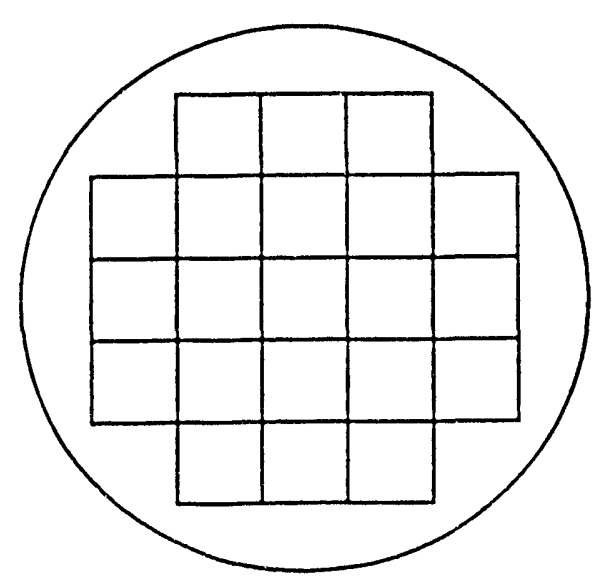

21 PWR Assemblies

Figure 2. Concept for Spent Fuel Waste Package Emplaced in a Drift. (Pedestal is Schematic only. Lifting devices and subsequent backfill are not shown.) 
Figure 3 shows a schematic view of a typical individual fuel rod in cross section. In a spent commercial fuel rod, radionuclides would exist in all of the components and on the surfaces. The radionuclides can be categorized by location and by their physical and chemical behavior.

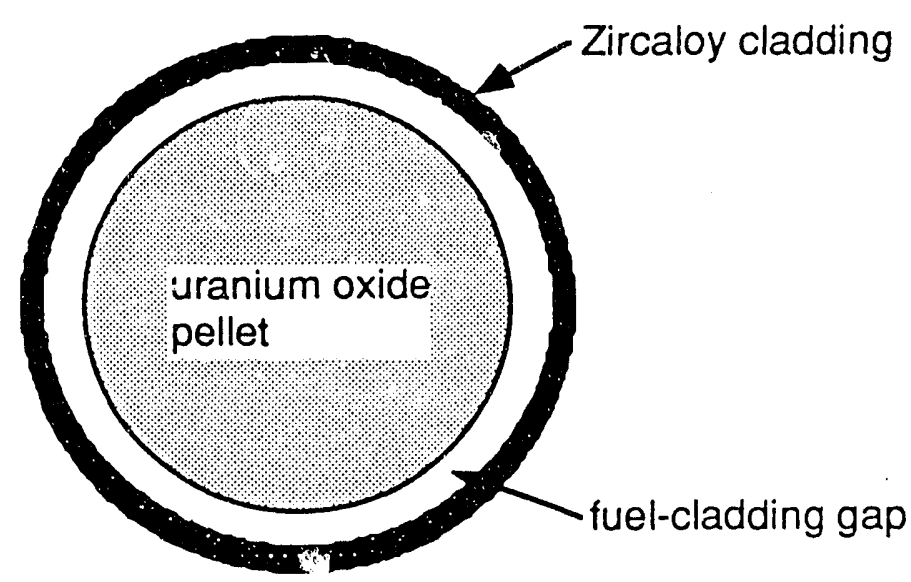

Figure 3. Schematic Cross-section of a Typical Fuel Pin

The locations we treat in PANDORA-1.1 are:

1. The oxidized outer layer of the cladding. A fraction of C-14 is here and can be released as a gas if the container is brearhed and air enters.

2. The fuel/cladding gap. A fraction of the fission-product volatiles and gases are located here and are available for relatively rapid release when the container and cladding are breached.

3. The spent fuel pellet matrix.

The locations we defer for future treatment are:

1. The outer layers of the cladding (except that we do treat C-14). A variable crud layer and an oxidized layer of cladding contain some radionuclides.

2. The cladding solid matrix.

3. The stainless steel or Inconel fuel assembly components. 
The physical/chemical behavior categories we treat in PANDORA-1.1 are:

1. Low solubility elements,

2. High solubility elements,

3. Gases, and

4. Short-lived daughter radionuclides whose presence is determined by the presence of the parent radionuclide.

The specifics of the treatment of these categories of radionuclides are given in Section 4.

\subsection{Processes Affecting the Waste Package}

The existence and rate of waste release from the waste package are dependent on three processes:

1. Existence of a breach of the barrier, opening a potential path between the waste form and the external medium.

2. Alteration of the waste form, converting some part of the waste into mobile form.

3. Transport of the mobile waste from the waste form to the surrounding rock.

The containment function is provided by an engineered container which may include nested sealed shells of different materials. Failure of complete containment of waste requires loss of container integrity (a breach) and a means to move waste out. We are interested in the breach times of the containers as a starting time for release-inducing processes as well as for meeting the containment function. We do not model the development of a breach, but we discuss the key features. The loss of barrier integrity can develop by either mechanical means (e.g., rupture due to stress) or chemical means (e.g., uniform corrosion, stress corrosion cracking, or pitting corrosion). The processes leading to loss of barrier integrity are influenced by the nearby external environment (e.g., rock failures causing localized stress on the waste package) and by groundwater flow. The processes are also influenced by the internal environment interacting with the external environment. Examples include (l) the heat 
generated by the radioactive waste being transferred to the external rock, thus establishing the temperature field; and (2) gamma radiation being generated by the waste and attenuated by the waste and by metal barriers, thus producing a net gamma ray flux at the surfaces of the metal barriers. The gamma ray flux can cause radiolysis in the water which might then increase the corrosion rate.

The current PANDORA-1.1 does not model the processes leading to loss of container integrity. Rather the time and mode of failure are taken as inputs specified by the user. At this time they would be hypothetical inputs. The design intent is to avoid container failure modes in the anticipated emplacement ervironments, at least within 300 to 1,000 years after closure of the repository [DOE, 1988, Sec. 8.3.5.9]. The actual failure occurrence will depend on the interaction of the container materials with a range of environments; on this subject extensive but partial information is available [LLNL, 1988; Farmer and McCright, 1988]. The actual failure will depend also on the development over time of some variations in local environments, which in turn depend on the rock mechanics, hydrology, and geochemistry of the near-field environment.

For spent fuel, the Zircaloy cladding can provide an additional barrier for containment of the fuel pellets and, even when partially breached, can help limit the rate of release of the waste inside. As a bounding simplifying approach in PANDORA-1.1, we assume that all of the Zircaloy claddings are breached.

Most radionuclides require water for mobilization and transport. The water movement and water contact with the waste form depend on the groundwater flow and its behavior at the borehole, and on the waste container condition, i.e., one small breach, several small breaches, many breaches, or total dismantlement. PANDORA-1.1 treats advective water flow, where there is enough water flow locally to form seeps or drips rather than just flow in the rock pores. Drips could bridge the isolation provided by the air gap. A rock/container contact area could allow a seep to get into a waste package.

Once inside a waste package, water could pond if there is only a breach near the top of the waste package, or water could trickle through if there is a breach near the bottom as well. These two container conditions determine the two water contact modes modeled, the bathtub mode and the flowthrough mode. In the 
bathtub mode, the container must fill before outflow starts. This could take hundreds or thousands of years. In the flowthrough mode, the water would contact a fraction of the waste form surface. The groundwater flux would have to provide enough water for a water film on this fraction of the surface before outflow starts. This would take a relatively short time. Input parameters encompassing these concepts are included in the PANDORA-1.1 model. PANDORA-1.1 uses these inputs and the principle of mass balance (assuming no evaporation) to track the internal hydrology over time.

The waste form alteration rate and elemental solubilities depend on temperature and on water chemistry. PANDORA-1.1 uses constant input values for these parameters, with the intent of using the largest values over an appropriate range. How much of a conservatism this is depends on the ranges and on how much the parameters change. The temperature in the waste package cools down very slowly, dependent on the cooldown of the rock [Nitao, 1988]. A bound on this range is from the boiling point down to the ambient at the repository level. The incoming water chemistry could conceivably change with time, as a prerepository level of water flux is gradually reestablished. The chemistry also depends on the rock temperature. If the water flux is very low, the waste form could have a noticeable effect on the water chemistry before it exits. Initial experiments [Wilson and Bruton, 1989; Wilson, 1990a,b] indicate that the variation of waste form alteration with temperature between $25^{\circ} \mathrm{C}$ and $80^{\circ} \mathrm{C}$ is by a factor between four and ten.

The transport of the dissolved radionuclides is by advection. In the bathtub mode, we assume mixing of the water in the bathtub. In the flowthrough mode, we assume sheet flow without mixing.

\section{PERFORMANCE ASSESSMENT AND ITS RELATIONSHIP TO WASTE PACKAGE DESIGN}

Integrated assessments of the performance of waste package designs must be made in order to qualify waste package designs with respect to the containment time and release rate requirements set by the NRC in 10 CFR 60. Assessments are also necessary to calculate releases to the accessible environment. To accomplish 
this, a source term of releases from the waste package as a function of time must be provided to the total repository system performance assessment.

The licensing process under 10 CFR 60 requires that two basic criteria be met by the Engineered Barrier System (EBS) after repository closure:

1. Substantially complete containment of high level waste within the waste packages for 300 to 1,000 years after permanent closure of the repository.

2. Annual release of any radionuclide not to exceed one part in 100,000 of the 1,000 year post-closure inventory of that radionuclide for a period consistent with the applicable Environmental Protection Agency standards for radioactivity (now defined to be 10,000 years by EPA regulations in $40 C F R$ 191). This limit does not apply to any radionuclide released at a rate less than $0.1 \%$ of the calculated limit on total release rate. (The calculated limit on total release rate is taken to be one part in 100,000 per year of the total inventory of radioactive waste in Curies remaining 1,000 years after emplacement.)

The release rates of radionuclides from breached waste packages are among the performance measures by which various waste package designs will be evaluated. We calculate the annual release rates of radionuclides, as a function of time, for use as the source term in total repository system performance assessment. We take the maximum over time of the fractional release rates of radionuclides as a performance measure for the waste package. We compare this fractional release rate with the NRC release rate criterion for the engineered barrier system although this is not a crucial comparison since the waste packages are not all expected to act in unison.

The performance of the waste package is affected by many processes acting in an interrelated manner over a long time duration. Given this complexity and the long periods discussed in the criteria above, long-term assessments will necessarily be based on computational models and short-term tests. It is the task of performance assessment to construct, link, and validate these computational models and then to analyze waste package designs to demonstrate that selected designs perform as required. These analyses will also guide the design process by allowing comparison of alternative waste package designs. Such models can help determine the sensitivity of performance to environmental and design 
parameters. Further, integrated performance calculations may indicate that the current envelope of types of tests and their conditions for the individual waste package processes requires expansion or allows reduction.

\section{MODEL DESCRIPTION}

\subsection{General}

PANDORA-1.1 addresses the performance measure of radionuclide release rates into the host rock from the waste package. This measure is related to the regulatory performance requirement of limited radionuclide release rates [10CFR60, 1991].

Figure 4 shows the sequence of tracking through time the release rate of radionuclides. The release rate is the result of alteration of the waste into mobile forms and the transport of the mobilized waste out of the waste package and into the host rock. The processes earlier in the causal chain, i.e., water flux initiation and container breach are described by user input parameters, and are combined into the state of the waste form environment by the environment model. The inpackage hydrology is described in part by inputs and in part by calculations combined with the waste form alteration process.

\subsection{System Model}

The system model combines the submodels and controls the time-stepping process. At each time step after breach of container, a series of calculations related to waste form alteration appropriate to the waste package condition are made.

The calculation starts at the container breach time which is specified by the user. The system model selects the size of the next time step at each step. The environment submodel determines if there is groundwater flowing into the waste package and computes the quantity of groundwater flow according to the input data. Based on the user-specified groundwater exposure scenarios, the 
waste form alteration submodel determines the amount of gaseous radionuclides mobilized and the concentration of waste radionuclides present in liquid groundwater inside the waste package. The radionuclide transport submodel then determines the release rate from the EBS for each radionuclide.

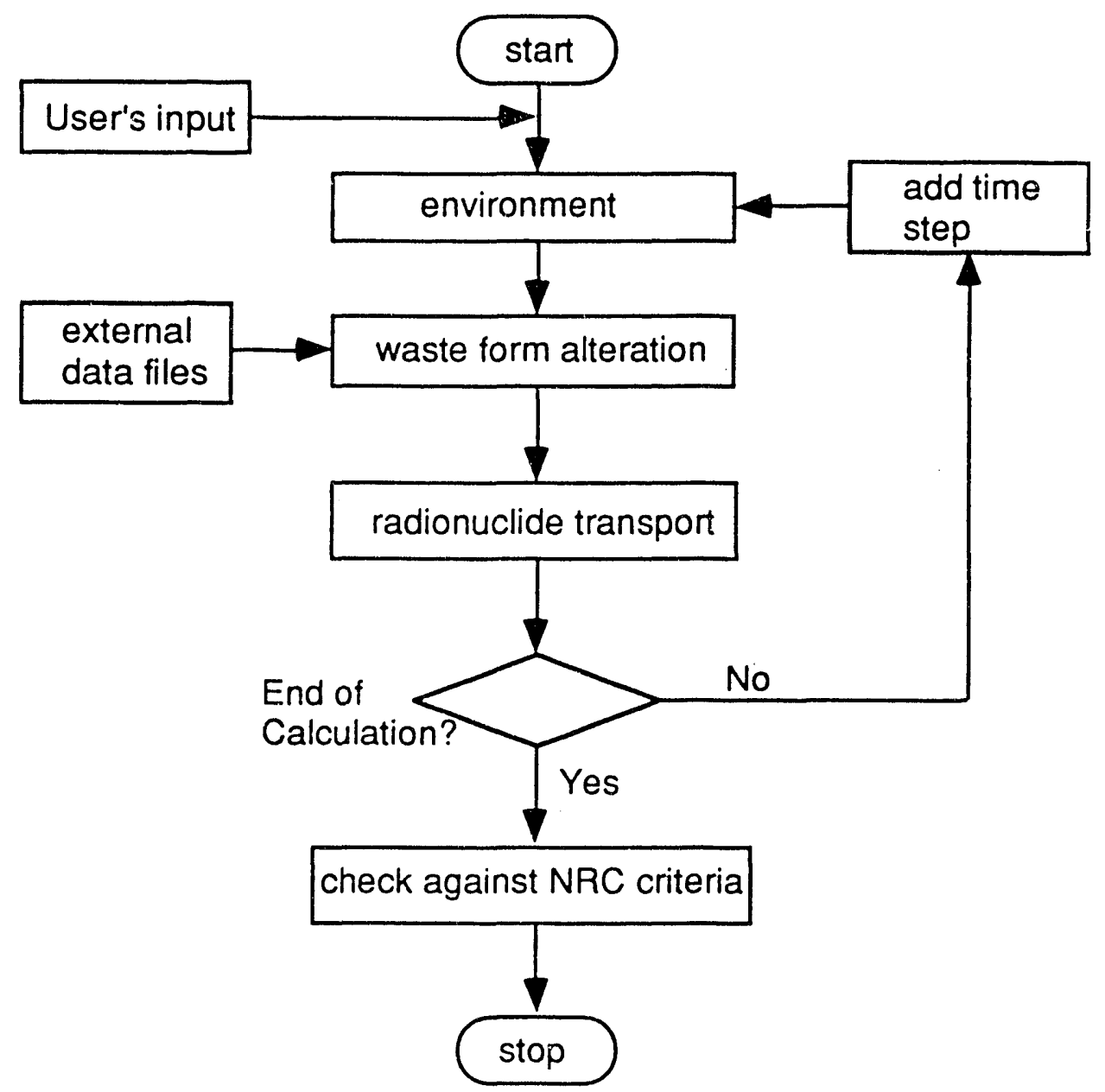

Figure 4. System Model of PANDORA-1.1

We use a one-year time step for the first 10 years after container failure, followed by a ten-year time step up to 100 years after failure, and a 100-year time step afterwards. When the ground water starts to flow out of the package, the time step changes to one year for the next 100 years. Then the time step changes to 100 years until the end of the calculation. For the flow-through ground water 
scenario, the time step change does not occur before the rapid release portion of radionuclides is flushed out.

This series of calculations is repeated at each time step. The time parameter, in turn, is updated by the amount of the time step following each series of calculations. The time stepping process continues until a specified post-closure time is reached, at which point the assessment is complete. The release rates of these radionuclides are then checked against the NRC criteria given in 10 CFR 60 as stated in Section 3.

Figure 4 provides a high-level schematic of the flow of control and data in the PANDORA-1.1 model.

\subsection{Environment Submodel}

According to the user-specified wetting time and subsequent steady inflow rate into the borehole, the environment submodel determines the status and rate of groundwater inflow at a given time. The borehole itself is assumed to be completely transmissive to groundwater, i.e., there is no holdup of groundwater within the borehole itself, only the waste package is able to retain significant quantities of groundwater. A user-specified fraction of the inflowing groundwater is assumed to enter the package. The remaining fraction of inflowing groundwater is assumed to immediately flow out of the borehole. The modeling of groundwater flow into and out of the waste package is handled within the waste form alteration submodel.

\subsection{Waste Form Alteration Submodel}

The waste form alteration submodel determines the rate of release of waste radionuclides in to air or water.

\section{4,4.1 Description of Radionuclides for Release}


Section 2.1 described the types and locations of radionuclides in spent fuel. This section discusses the list of radionuclides to be analyzed, the inventories versus time, and the grouping of radionuclides into categories, as well as some properties of these categories.

Table 2 lists the 122 radionuclides tracked by PANDORA-1.1, together with their half-lives and specific activities. These are contained in an internal data file. The user can select a shorter list of radionuclides for evaluation and output. The half life and specific activity are related by

specific activity $=K /$ half life

where $\mathrm{K}=1.13 \times 10^{13}$ (seconds $\times$ Curies/mole).

The list was selected to include all radionuclides possibly of interest in evaluation of post-closure performance of a nuclear waste disposal system. It covers radionuclides possibly of interest in spent fuel and glass-based high level waste from reprocessing. The list includes fission products, activation products, and transuranic elements. The list also includes activation products of fission products, such as Cs-134 from activation of the stable fission product Cs-133.

The extensive list is a first step in documenting whether some of these radionuclides need not be on the list. If the inventory is negligibly small, or if the half life is short compared to the breach time or geohydrologic transport time in a scenario, then a radionuclide could be set aside without a detailed calculation. The NRC release rate rule (see Sec. 3 ) has an exception for any radionuclide released at a yearly rate lower than $10^{-8}$ fraction of the total 1000-year inventory of Curies. If the total inventory of a radionuclide is less than this fraction during times of interest, then the release of that radionuclide cannot violate the NRC limit, and hence does not have to be calculated. This procedure may be performed once for a family of calculations, but, if the waste form or regilatory application changes, caution is required. For example, some radionuclides build up more than linearly with burnup, and may become significant in high-burnup spent fuels. The EPA limit on total Curies released to the accessible environment has different weighting factors for the radionuclides. The EPA individual dose limit also implicitly contains different weighting factors. Glass-based HLW from 
Table 2

Radionuclides Tracked by PANDORA

\begin{tabular}{|c|c|c|c|}
\hline No. & $\begin{array}{c}\text { Radionuclide } \\
\text { Symbol }\end{array}$ & $\begin{array}{l}\text { Half-life } \\
\text { (sec) }\end{array}$ & $\begin{array}{l}\text { Specific Activity } \\
\text { (curies / mole) }\end{array}$ \\
\hline 1 & $\mathrm{H3}$ & $3.89 E+08$ & $2.90 \mathrm{E}+04$ \\
\hline 2 & C 14 & $1.80 \mathrm{E}+11$ & $6.25 E+01$ \\
\hline 3 & $\mathrm{Cl} 36$ & $9.48 \mathrm{E}+12$ & $1.19 E+00$ \\
\hline 4 & $\mathrm{Ca} 41$ & $3.15 \mathrm{E}+12$ & $3.58 \mathrm{E}+00$ \\
\hline 5 & Fe 55 & $8.48 \mathrm{E}+07$ & $1.33 \mathrm{E}+05$ \\
\hline 6 & Co 60 & $1.66 \mathrm{E}+08$ & $6.79 E+04$ \\
\hline 7 & Ni 59 & $2.36 \mathrm{E}+12$ & $4.77 \mathrm{E}+00$ \\
\hline 8 & $\mathrm{Ni} 63$ & $3.15 E+09$ & $3.58 \mathrm{E}+03$ \\
\hline 9 & Se 79 & $2.05 E+12$ & $5.51 E+00$ \\
\hline 10 & $\mathrm{Kr} 85$ & $3.38 E+08$ & $3.34 \mathrm{E}+04$ \\
\hline 11 & $\mathrm{Rb} 87$ & $1.51 E+18$ & $7.46 \mathrm{E}-06$ \\
\hline 12 & Sr 90 & $9.09 E+08$ & $1.24 \mathrm{E}+04$ \\
\hline 13 & Y90 & $2.31 E+05$ & $4.89 E+07$ \\
\hline 14 & $\mathrm{Zr} 93$ & $4.72 \mathrm{E}+13$ & $2.39 E-01$ \\
\hline 15 & $\mathrm{Nb} 93 \mathrm{~m}$ & $4.29 E+08$ & $2.63 E+04$ \\
\hline 16 & $\mathrm{Nb} 94$ & $6.30 \mathrm{E}+11$ & $1.79 \mathrm{E}+01$ \\
\hline 17 & Mo 93 & $9.48 \mathrm{E}+10$ & $1.19 E+02$ \\
\hline 18 & Tc 99 & $6.75 E+12$ & $1.67 \mathrm{E}+00$ \\
\hline 19 & Ru106 & $3.17 \mathrm{E}+07$ & $3.56 \mathrm{E}+05$ \\
\hline 20 & Rh106 & $2.98 E+01$ & $3.79 E+11$ \\
\hline 21 & Pd107 & $2.05 E+14$ & $5.51 \mathrm{E}-0 ?$ \\
\hline 22 & Ag108 & $1.44 \mathrm{E}+02$ & $7.84 \mathrm{E}+10$ \\
\hline 23 & Ag108m & $4.00 \mathrm{E}+09$ & $2.82 \mathrm{E}+03$ \\
\hline 24 & Ag110m & $2.18 \mathrm{E}+07$ & $5.18 \mathrm{E}+05$ \\
\hline 25 & $\mathrm{Cd} 113$ & $2.83 E+23$ & $3.98 \mathrm{E}-11$ \\
\hline 26 & $\mathrm{Sn} 119 \mathrm{~m}$ & $2.16 \mathrm{E}+07$ & $5.23 E+05$ \\
\hline 27 & Sn121 & $9.72 \mathrm{E}+04$ & $1.16 \mathrm{E}+08$ \\
\hline 28 & $\mathrm{Sn} 121 \mathrm{~m}$ & $1.73 E+09$ & $6.51 \mathrm{E}+03$ \\
\hline 29 & Sn126 & $3.15 \mathrm{E}+12$ & $3.58 \mathrm{E}+00$ \\
\hline 30 & Sb125 & $8.48 \mathrm{E}+07$ & $1.33 \mathrm{E}+05$ \\
\hline 31 & Sb126 & $1.07 \mathrm{E}+06$ & $1.05 E+07$ \\
\hline 32 & Sb126m & $1.14 \mathrm{E}+03$ & $9.90 E+09$ \\
\hline 33 & $\mathrm{Te} 125 \mathrm{~m}$ & $5.01 E+06$ & $2.25 E+06$ \\
\hline 34 & I129 & $5.03 \mathrm{E}+14$ & $2.24 \mathrm{E}-02$ \\
\hline 35 & Cs134 & $6.48 \mathrm{E}+07$ & $1.74 \mathrm{E}+05$ \\
\hline 36 & Cs135 & $9.48 \mathrm{E}+13$ & $1.19 \mathrm{E}-01$ \\
\hline 37 & Cs137 & $9.48 \mathrm{E}+08$ & $1.19 \mathrm{E}+04$ \\
\hline 38 & $\mathrm{Ba} 137 \mathrm{~m}$ & $1.53 \mathrm{E}+02$ & $7.37 \mathrm{E}+10$ \\
\hline
\end{tabular}


Table 2 (continued)

\begin{tabular}{|c|c|c|c|}
\hline 39 & Ce144 & $2.45 E+07$ & $4.60 \mathrm{E}+05$ \\
\hline 40 & Pr144 & $1.03 \mathrm{E}+03$ & $1.09 E+10$ \\
\hline 41 & Nd144 & $6.63 E+22$ & $1.70 \mathrm{E}-10$ \\
\hline 42 & Pm146 & $1.73 E+08$ & $6.51 E+04$ \\
\hline 43 & $\overline{P m 147}$ & $8.29 \mathrm{E}+07$ & $1.36 \mathrm{E}+05$ \\
\hline 44 & Sm147 & $3.34 \mathrm{E}+18$ & $3.38 \mathrm{E}-06$ \\
\hline 45 & Sm148 & $2.52 E+23$ & $4.47 \mathrm{E}-11$ \\
\hline 46 & Sm151 & $2.83 E+09$ & $3.98 E+03$ \\
\hline 47 & Eu152 & $4.10 \mathrm{E}+08$ & $2.75 E+04$ \\
\hline 48 & $\overline{\text { Eu154 }}$ & $2.68 E+08$ & $4.21 E+04$ \\
\hline 49 & Eu155 & $1.54 \mathrm{E}+08$ & $7.30 E+04$ \\
\hline 50 & Gd153 & $7.62 E+09$ & $1.48 \mathrm{E}+03$ \\
\hline 51 & Ho166m & $3.78 E+10$ & $2.98 \mathrm{E}+02$ \\
\hline 52 & T1207 & $2.86 \mathrm{E}+02$ & $3.94 \mathrm{E}+10$ \\
\hline 53 & T1208 & $1.83 \mathrm{E}+02$ & $6.16 \mathrm{E}+10$ \\
\hline 54 & Pb209 & $1.17 \mathrm{E}+04$ & $9.65 E+08$ \\
\hline 55 & Pb210 & $7.05 E+08$ & $1.60 \mathrm{E}+04$ \\
\hline 56 & Pb211 & $2.16 \mathrm{E}+03$ & $5.21 E+09$ \\
\hline 57 & PL212 & $3.82 \mathrm{E}+04$ & $2.95 E+08$ \\
\hline 58 & Pb214 & $1.61 E+03$ & $7.02 E+09$ \\
\hline 59 & Bi210 & $4.32 \mathrm{E}+05$ & $2.61 E+07$ \\
\hline 60 & Bi211 & $1.29 \mathrm{E}+02$ & $8.75 \mathrm{E}+10$ \\
\hline 61 & $\mathrm{Bi} 212$ & $3.64 \mathrm{E}+03$ & $3.10 \mathrm{E}+09$ \\
\hline 62 & Bi213 & $2.73 E+03$ & $4.13 \mathrm{E}+09$ \\
\hline 63 & $\overline{\mathrm{Bi} 214}$ & $1.18 \mathrm{E}+03$ & $9.55 E+09$ \\
\hline 64 & Po210 & $1.19 E+07$ & $9.44 E+05$ \\
\hline 65 & Po212 & $3.00 \mathrm{E}-07$ & $3.76 E+19$ \\
\hline 66 & Po213 & $4.00 \mathrm{E}-06$ & $2.82 E+18$ \\
\hline 67 & Po214 & $1.64 \mathrm{E}-04$ & $6.88 \mathrm{E}+16$ \\
\hline 68 & Po215 & $1.78 \mathrm{E}-03$ & $6.34 E+15$ \\
\hline 69 & Po216 & $1.50 \mathrm{E}-01$ & $7.52 \mathrm{E}+13$ \\
\hline 70 & Po218 & $1.83 \mathrm{E}+02$ & $6.17 \mathrm{E}+10$ \\
\hline 71 & At217 & $3.23 E-02$ & $3.49 E+14$ \\
\hline 72 & Rn219 & $3.96 \mathrm{E}+00$ & $2.85 E+12$ \\
\hline 73 & Rn220 & $5.55 \mathrm{E}+01$ & $2.03 E+11$ \\
\hline 74 & Rn222 & $3.30 \mathrm{E}+05$ & $3.42 \mathrm{E}+07$ \\
\hline 75 & Fr221 & $2.88 \mathrm{E}+02$ & $3.92 E+10$ \\
\hline 76 & Ra223 & $9.89 \mathrm{E}+05$ & $1.14 \mathrm{E}+07$ \\
\hline 77 & Ra224 & $3.16 \mathrm{E}+05$ & $3.57 \mathrm{E}+07$ \\
\hline 78 & Ra225 & $1.28 \mathrm{E}+06$ & $8.83 E+06$ \\
\hline 79 & Ra226 & $5.03 E+10$ & $2.24 E+02$ \\
\hline 80 & Ra228 & $1.82 \mathrm{E}+08$ & $6.21 E+04$ \\
\hline
\end{tabular}


Table 2 (continued)

\begin{tabular}{|c|c|c|c|}
\hline 81 & Ac225 & $8.61 E+05$ & $1.31 \mathrm{E}+07$ \\
\hline 82 & Ac227 & $6.88 \mathrm{E}+08$ & $1.64 \mathrm{E}+04$ \\
\hline 83 & Th227 & $1.62 \mathrm{E}+06$ & $6.98 E+06$ \\
\hline 84 & Th228 & $6.03 \mathrm{E}+07$ & $1.87 E+05$ \\
\hline 85 & Th229 & $2.30 \mathrm{E}+11$ & $4.90 \mathrm{E}+01$ \\
\hline 86 & Th230 & $2.52 E+12$ & $4.47 \mathrm{E}+00$ \\
\hline 87 & Th231 & $9.17 \mathrm{E}+04$ & $1.23 E+08$ \\
\hline 88 & Th232 & $4.44 \mathrm{E}+17$ & $2.54 \mathrm{E}-0 \mathrm{j}$ \\
\hline 89 & Th234 & $2.08 E+06$ & $5.42 E+06$ \\
\hline 90 & Pa2.31 & $1.03 E+12$ & $1.09 \mathrm{E}+01$ \\
\hline 91 & Pa233 & $2.33 \mathrm{E}+06$ & $4.84 E+06$ \\
\hline 92 & Pa234 & $2.43 E+04$ & $4.64 E+08$ \\
\hline 93 & Pa234m & $7.05 \mathrm{E}+01$ & $1.60 \mathrm{E}+11$ \\
\hline 94 & U232 & $2.27 \mathrm{E}+09$ & $4.97 \mathrm{E}+03$ \\
\hline 95 & U233 & $5.01 \mathrm{E}+12$ & $2.25 E+00$ \\
\hline 96 & U234 & $7.72 \mathrm{E}+12$ & $1.46 \mathrm{E}+00$ \\
\hline 97 & U235 & $2.22 \mathrm{E}+16$ & $5.09 \mathrm{E}-04$ \\
\hline 98 & U236 & $7.37 \mathrm{E}+14$ & $1.53 \mathrm{E}-02$ \\
\hline 99 & U237 & $5.81 E+05$ & $1.94 \mathrm{E}+07$ \\
\hline 100 & U238 & $1.41 \mathrm{E}+17$ & $8.01 E-05$ \\
\hline 101 & Np237 & $6.54 \mathrm{E}+13$ & $1.67 \mathrm{E}-01$ \\
\hline 102 & Np238 & $1.83 E+05$ & $6.17 \mathrm{E}+07$ \\
\hline 103 & Np239 & $2.03 E+05$ & $5.56 \mathrm{E}+07$ \\
\hline 104 & Pu236 & $8.95 E+07$ & $1.26 \mathrm{E}+05$ \\
\hline 105 & Pu237 & $3.92 E+06$ & $2.88 \mathrm{E}+06$ \\
\hline 106 & Pu238 & $2.76 \mathrm{E}+09$ & $4.08 \mathrm{E}+03$ \\
\hline 107 & Pu239 & $7.57 \mathrm{E}+11$ & $1.49 \mathrm{E}+01$ \\
\hline 108 & Pu240 & $2.07 \mathrm{E}+11$ & $5.45 \mathrm{E}+01$ \\
\hline 109 & Pu241 & $4.53 E+08$ & $2.49 E+04$ \\
\hline 110 & Pu242 & $1.18 \mathrm{E}+13$ & $9.52 \mathrm{E}-01$ \\
\hline 111 & $\mathrm{Pu} 244$ & $2.55 E+15$ & $4.42 E-03$ \\
\hline 112 & Am241 & $1.36 \mathrm{E}+10$ & $8.27 \mathrm{E}+02$ \\
\hline 113 & Am242 & $5.75 E+04$ & $1.96 \mathrm{E}+08$ \\
\hline 114 & $\mathrm{Am} 242 \mathrm{~m}$ & $4.80 \mathrm{E}+09$ & $2.35 \mathrm{E}+03$ \\
\hline 115 & $\operatorname{Ain} 243$ & $2.32 \mathrm{E}+11$ & $4.86 \mathrm{E}+01$ \\
\hline 116 & $\mathrm{Cm} 242$ & $1.41 \mathrm{E}+07$ & $8.02 E+05$ \\
\hline 117 & $\mathrm{Cm} 243$ & $8.95 E+08$ & $1.26 \mathrm{E}+04$ \\
\hline 118 & $\mathrm{Cm} 244$ & $5.69 \mathrm{E}+08$ & $1.98 \mathrm{E}+04$ \\
\hline 119 & Cm245 & $2.68 \mathrm{E}+11$ & $4.21 \mathrm{E}+01$ \\
\hline 120 & $\mathrm{Cm} 246$ & $1.48 \mathrm{E}+11$ & $7.61 \mathrm{E}+01$ \\
\hline 121 & $\mathrm{Cm} 247$ & $5.03 \mathrm{E}+14$ & $2.24 \mathrm{E}-02$ \\
\hline 122 & $\mathrm{Cm} 248$ & $1.11 E+13$ & $1.02 \mathrm{E}+00$ \\
\hline
\end{tabular}


reprocessing has a different makeup of inventory, hence some radionuclides not of significance in spent fuel may be above the threshold of significance in the glass waste package.

The inventories of the tracked radionuclides in Curies per metric ton initial heavy metals (MTIHM) at various years out-of-reactor are given in external data files according to the year out of reactor. Table 3 shows an example of inventories of radionuclides for selected times for a PWR spent fuel with a burnup of 33,000 MWd/MTIHM. The table is based on the Oak Ridge database generated using ORIGEN-2 [DOE, 1987]. PANDORA-1.1 determines the inventories at a desired year by interpolation. The interpolation algorithm to extract radionuclide inventory time histories from tabulated data incorporates numerical techniques to locate inflection points in radionuclide inventory curves. Cubic spline interpolation is used during the time periods when there are significant amounts of radioactive decay daughter products. Semilogarithmic interpolation is used elsewhere.

The first radionuclide released will probably be C-14 from the outer oxidized layer of the cladding. Experiments conducted in air at a high temperature $\left(275^{\circ} \mathrm{C}\right)$ have shown that there is an initial rapid release of about $0.25 \%$ to $3 \%$ of a fuel assembly's inventory of C-14 as $\mathrm{CO}_{2}$ gas [Van Konynenburg, et al., 1984; Smith, 1989]. The fraction of prompt release is an input data element of the waste form alteration submodel.

As shown in Figure 3 , an intact fuel pin cladding effectively serves as a barrier to water contact with the fuel pellet and to release of gases inside the fuel pin, particularly the gases trapped in the fuel-clad gap. Consequently, there is considerable interest in the clad integrity as a possible barrier to radionuclide release. However, the PANDORA model presently does not assume any containment characteristics of the Zircaloy cladding. In the PANDORA-1.1 model, when a container is breached, it is assumed that the gaseous inventory of the fuel-cladding gap is available for immediate release by rapid gaseous diffusion at the same time as the $\mathrm{C}-14$ fraction from the outer layer of the cladding. In the model, when the container is breached and water enters, it is assumed that the cladding presents no barrier to the water contacting the fuelcladding gap and the spent fuel matrix surface. 
Table 3

Radionuclide Inventories for Reference Commercial Spent Fuel (Curies/MTIHM)

\begin{tabular}{|c|c|c|c|c|}
\hline \multirow[b]{2}{*}{ No. } & \multirow[b]{2}{*}{ Radionuclide } & \multicolumn{3}{|c|}{ Years Out of Reactor } \\
\hline & & Yr 50 & Yr 1000 & Yr 5000 \\
\hline 1 & $\mathrm{H} 3$ & $4.91 E+01$ & $0.00 \mathrm{E}+00$ & $0.00 \mathrm{E}+00$ \\
\hline 2 & C 14 & $1.54 \mathrm{E}+00$ & $1.37 \mathrm{E}+00$ & $8.47 \mathrm{E}-01$ \\
\hline 3 & $\mathrm{Cl} 36$ & $1.22 \mathrm{E}-02$ & $1.21 \mathrm{E}-02$ & $1.20 \mathrm{E}-02$ \\
\hline$\overline{4}$ & $\mathrm{Ca} 41$ & $1.93 \mathrm{E}-04$ & $1.91 \mathrm{E}-04$ & $1.85 \bar{E}-04$ \\
\hline 5 & Fe 55 & $9.09 E-03$ & $0.00 \mathrm{E}+00$ & $0.00 \mathrm{E}+00$ \\
\hline 6 & Co 60 & $1.10 E+01$ & $0.00 E+00$ & $0.00 \mathrm{E}+00$ \\
\hline 7 & Ni 59 & $5.15 E+00$ & $5.11 E+00$ & $4.93 \mathrm{E}+00$ \\
\hline 8 & $\mathrm{Ni} 63$ & $4.82 E+02$ & $3.75 E-01$ & $3.06 \mathrm{E}-14$ \\
\hline 9 & Se 79 & $4.08 \mathrm{E}-01$ & $4.04 \mathrm{E}-01$ & $3.87 \mathrm{E}-01$ \\
\hline 10 & $\mathrm{Kr} 85$ & $3.65 \mathrm{E}+02$ & $0.00 \mathrm{E}+00$ & $0.00 \mathrm{E}+00$ \\
\hline 11 & $\overline{\mathrm{Rb}} 87$ & $2.13 E-05$ & $2.13 E-05$ & $2.13 \mathrm{E}-05$ \\
\hline 12 & Sr 90 & $2.21 E+04$ & $3.34 \mathrm{E}-06$ & $0.00 \mathrm{E}+00$ \\
\hline 13 & Y90 & $2.21 E+04$ & $3.34 \mathrm{E}-06$ & $0.00 \mathrm{E}+00$ \\
\hline 14 & Zr 93 & $1.93 \mathrm{E}+00$ & $1.93 \mathrm{E}+00$ & $1.93 \mathrm{E}+00$ \\
\hline 15 & $\mathrm{Nb} 93 \mathrm{~m}$ & $1.70 \mathrm{E}+00$ & $1.83 \mathrm{E}+00$ & $1.83 E+00$ \\
\hline 16 & $\mathrm{Nb} 94$ & $1.28 \mathrm{E}+00$ & $1.24 \mathrm{E}+00$ & $1.08 \mathrm{E}+00$ \\
\hline 17 & Mo 93 & $2.57 \mathrm{E}-02$ & $2.13 E-02$ & $9.63 E-03$ \\
\hline 18 & Tc 99 & $1.31 \mathrm{E}+01$ & $1.30 E+01$ & $1.28 \mathrm{E}+01$ \\
\hline 19 & $\overline{R u} 106$ & $6.34 E-10$ & $0.00 E+00$ & $0.00 E+00$ \\
\hline 20 & $\overline{R h 106}$ & $6.34 \mathrm{E}-10$ & $0.00 E+00$ & $0.00 E+00$ \\
\hline 21 & Pd107 & $1.12 \mathrm{E}-01$ & $1.12 E-01$ & $1.12 \mathrm{E}-01$ \\
\hline 22 & Ag108 & $8.93 E-04$ & $5.00 \mathrm{E}-06$ & $0.00 E+00$ \\
\hline 23 & Ag108m & $1.00 \mathrm{E}-02$ & $5.62 E-05$ & $1.86 \mathrm{E}-14$ \\
\hline 24 & Ag110m & $4.22 \mathrm{E}-19$ & $0.00 E+00$ & $0.00 \mathrm{E}+00$ \\
\hline 25 & Cd113 & $5.19 E+00$ & $1.30 \mathrm{E}-19$ & $0.00 E+00$ \\
\hline 26 & Sn119m & $2.17 E-19$ & $0.00 E+00$ & $0.00 E+00$ \\
\hline 27 & Sn121 & $0.00 \mathrm{E}+00$ & $0.00 E+00$ & $0.00 \mathrm{E}+00$ \\
\hline 28 & $\mathrm{Sn} 121 \mathrm{~m}$ & $3.92 \mathrm{E}-01$ & $7.42 \mathrm{E}-07$ & $0.00 E+00$ \\
\hline 29 & $\operatorname{Sn} 126$ & $7.76 \mathrm{E}-01$ & $7.71 \mathrm{E}-01$ & $7.50 \mathrm{E}-01$ \\
\hline 30 & Sb125 & $5.78 E-02$ & $0.00 \mathrm{E}+00$ & $0.00 \mathrm{E}+00$ \\
\hline 31 & Sb126 & $1.09 \mathrm{E}-01$ & $1.08 \mathrm{E}-01$ & $1.05 \mathrm{E}-01$ \\
\hline 32 & Sb126m & $7.76 \mathrm{E}-01$ & $7.71 E-01$ & $7.50 \mathrm{E}-01$ \\
\hline 33 & Te125m & $1.41 \mathrm{E}-02$ & $0.00 \mathrm{E}+00$ & $0.00 \mathrm{E}+00$ \\
\hline 34 & I129 & $3.15 \mathrm{E}-02$ & $3.15 \mathrm{E}-02$ & $3.15 \mathrm{E}-02$ \\
\hline 35 & Cs134 & $7.55 \mathrm{E}-03$ & $0.00 \mathrm{E}+00$ & $0.00 \mathrm{E}+00$ \\
\hline 36 & Cs135 & $3.45 \mathrm{E}-01$ & $3.45 \mathrm{E}-01$ & $3.45 \mathrm{E}-01$ \\
\hline 37 & Cs137 & $3.26 \mathrm{E}+04$ & $9.55 E-06$ & $0.00 \mathrm{E}+00$ \\
\hline 38 & $\mathrm{Ba} 137 \mathrm{~m}$ & $3.08 E+04$ & $9.04 E-06$ & $0.00 \mathrm{E}+00$ \\
\hline
\end{tabular}


Table 3 (continued)

\begin{tabular}{|c|c|c|c|c|}
\hline 39 & Ce144 & $5.04 \mathrm{E}-14$ & $0.00 \mathrm{E}+00$ & $0.00 \mathrm{E}+00$ \\
\hline 40 & Pr144 & $5.04 \mathrm{E}-14$ & $0.00 \mathrm{E}+00$ & $0.00 \mathrm{E}+00$ \\
\hline 41 & Nd144 & $1.56 \mathrm{E}-09$ & $1.56 \mathrm{E}-09$ & $1.56 \mathrm{E}-09$ \\
\hline$\overline{42}$ & Pm146 & $5.67 \mathrm{E}-03$ & $0.00 \mathrm{E}+00$ & $0.00 \mathrm{E}+00$ \\
\hline 43 & Pm147 & $0.00 \mathrm{E}+00$ & $0.00 E+00$ & $0.00 E+00$ \\
\hline 44 & Sm147 & $4.75 \mathrm{E}-06$ & $4.75 \mathrm{E}-06$ & $4.75 E-06$ \\
\hline 45 & Sm148 & $5.01 \mathrm{E}-11$ & $5.01 \mathrm{E}-11$ & $5.01 \mathrm{E}-11$ \\
\hline 46 & Sm151 & $2.43 E+02$ & $1.62 \mathrm{E}-01$ & $6.73 E-15$ \\
\hline 47 & Eu152 & $4.82 \mathrm{E}-01$ & $0.00 \mathrm{E}+00$ & $0.00 \mathrm{E}+00$ \\
\hline 48 & Eu154 & $1.87 \mathrm{E}+02$ & $0.00 \mathrm{E}+00$ & $0.00 \mathrm{E}+00$ \\
\hline 49 & Eu155 & $5.97 \mathrm{E}+00$ & $0.00 \mathrm{E}+00$ & $0.00 \mathrm{E}+00$ \\
\hline 50 & Gd153 & $0.00 \mathrm{E}+00$ & $0.00 E+00$ & $0.00 \mathrm{E}+00$ \\
\hline 51 & Ho166m & $2.48 \mathrm{E}-03$ & $1.43 \mathrm{E}-03$ & $1.42 \mathrm{E}-04$ \\
\hline 52 & T1207 & $2.16 \mathrm{E}-05$ & $3.78 \mathrm{E}-04$ & $1.81 \mathrm{E}-03$ \\
\hline 53 & T1208 & $8.05 E-03$ & $1.04 \mathrm{E}-06$ & $1.96 \mathrm{E}-07$ \\
\hline 54 & Pb209 & $3.67 \mathrm{E}-07$ & $1.26 \mathrm{E}-04$ & $4.38 \mathrm{E}-03$ \\
\hline 55 & $\mathrm{~Pb} 210$ & $2.47 \mathrm{E}-06$ & $3.12 \mathrm{E}-03$ & $5.21 \mathrm{E}-02$ \\
\hline 56 & $\mathrm{~Pb} 211$ & $2.16 \mathrm{E}-05$ & $3.79 \mathrm{E}-04$ & $1.82 \mathrm{E}-03$ \\
\hline 57 & $\mathrm{~Pb} 212$ & $2.24 \mathrm{E}-02$ & $2.88 \mathrm{E}-06$ & $5.45 \bar{E}-07$ \\
\hline 58 & $\mathrm{~Pb} 214$ & $6.60 \mathrm{E}-06$ & $3.12 \mathrm{E}-03$ & $5.21 E-02$ \\
\hline 59 & $\mathrm{Bi210}$ & $2.47 \mathrm{E}-06$ & $3.12 E-03$ & $5.21 E-02$ \\
\hline 60 & $\mathrm{Bi} 211$ & $2.16 \mathrm{E}-05$ & $3.79 \mathrm{E}-04$ & $1.82 \mathrm{E}-03$ \\
\hline 61 & $\mathrm{Bi} 212$ & $2.24 \mathrm{E}-02$ & $2.88 \mathrm{E}-06$ & $5.45 \mathrm{E}-07$ \\
\hline 62 & $\mathrm{Bi} 213$ & $3.67 \mathrm{E}-07$ & $1.26 \mathrm{E}-04$ & $4.38 \mathrm{E}-03$ \\
\hline 63 & Bi214 & $6.60 \mathrm{E}-06$ & $3.12 E-03$ & $5.21 E-02$ \\
\hline 64 & Po210 & $2.47 \mathrm{E}-06$ & $3.12 \mathrm{E}-03$ & $5.21 \mathrm{E}-02$ \\
\hline 65 & Po212 & $1.43 \mathrm{E}-02$ & $0.00 \mathrm{E}+00$ & $0.00 \mathrm{E}+00$ \\
\hline 66 & Po213 & $3.59 \mathrm{E}-07$ & $1.23 \mathrm{E}-04$ & $4.29 E-03$ \\
\hline 67 & Po214 & $6.59 E-06$ & $3.12 \mathrm{E}-03$ & $5.21 E-02$ \\
\hline 68 & Po215 & $2.16 \mathrm{E}-05$ & $3.79 \mathrm{E}-04$ & $1.82 \mathrm{E}-03$ \\
\hline 69 & Po216 & $2.24 \mathrm{E}-02$ & $2.88 \mathrm{E}-06$ & $5.45 E-07$ \\
\hline 7() & Po218 & $6.60 \mathrm{E}-06$ & $3.12 \mathrm{E}-03$ & $5.21 \mathrm{E}-02$ \\
\hline 71 & At217 & $3.67 \mathrm{E}-07$ & $1.26 \mathrm{E}-04$ & $4.38 \mathrm{E}-03$ \\
\hline 72 & Rn219 & $2.16 \mathrm{E}-05$ & $3.79 E-04$ & $1.82 \mathrm{E}-03$ \\
\hline 73 & Rn220 & $2.24 \mathrm{E}-02$ & $2.88 \mathrm{E}-06$ & $5.45 \mathrm{E}-07$ \\
\hline 74 & Rn222 & $6.60 E-06$ & $3.12 \mathrm{E}-03$ & $5.21 E-02$ \\
\hline 75 & Fr221 & $3.67 \mathrm{E}-07$ & $1.26 \mathrm{E}-04$ & $4.38 \mathrm{E}-03$ \\
\hline 76 & Ra223 & $2.16 E-05$ & $3.79 \mathrm{E}-04$ & $1.82 \mathrm{E}-03$ \\
\hline 77 & Ra224 & $2.24 E-02$ & $2.88 \mathrm{E}-06$ & $5.45 \mathrm{E}-07$ \\
\hline 78 & Ra225 & $3.67 \mathrm{E}-07$ & $1.26 \mathrm{E}-04$ & $4.38 E-03$ \\
\hline 79 & Ra226 & $6.60 \mathrm{E}-06$ & $3.12 \mathrm{E}-03$ & $5.21 \mathrm{E}-02$ \\
\hline 80 & Ra228 & $5.34 \mathrm{E}-10$ & $1.30 \mathrm{E}-08$ & $7.14 \mathrm{E}-08$ \\
\hline
\end{tabular}


Table 3 (continued)

\begin{tabular}{|c|c|c|c|c|}
\hline 81 & Ac225 & 3.67E-07 & $1.26 \mathrm{E}-04$ & $4.38 \mathrm{E}-03$ \\
\hline 82 & Ac227 & $2.16 \mathrm{E}-05$ & $3.79 E-04$ & $1.82 \mathrm{E}-03$ \\
\hline 83 & Th227 & $2.13 \mathrm{E}-05$ & $3.74 \mathrm{E}-04$ & $1.79 \mathrm{E}-03$ \\
\hline 84 & Th228 & $2.24 \mathrm{E}-02$ & $2.88 E-(16$ & $5.45 \mathrm{E}-07$ \\
\hline 85 & Th229 & $3.67 \mathrm{E}-07$ & $1.26 \mathrm{E}-04$ & $4.38 \mathrm{E}-03$ \\
\hline 86 & Th230 & $6.05 E-04$ & $1.72 \mathrm{E}-02$ & $8.80 \mathrm{E}-02$ \\
\hline 87 & Th231 & $1.72 \mathrm{E}-02$ & $1.75 \mathrm{E}-02$ & $1.87 \mathrm{E}-02$ \\
\hline 88 & Th232 & $6.56 \mathrm{E}-10$ & $1.30 \mathrm{E}-08$ & $7.14 \mathrm{E}-08$ \\
\hline 89 & Th234 & $3.17 \mathrm{E}-01$ & $3.17 \mathrm{E}-01$ & $3.17 \mathrm{E}-01$ \\
\hline 90 & Pa231 & $3.38 \mathrm{E}-05$ & $3.79 E-04$ & $1.82 \mathrm{E}-03$ \\
\hline 91 & Pa233 & $3.54 \mathrm{E}-01$ & $9.99 E-01$ & $1.18 E+00$ \\
\hline 92 & Pa234 & $4.13 E-04$ & $4.13 E-04$ & $4.13 E-04$ \\
\hline$\overline{93}$ & $\mathrm{~Pa} 234 \mathrm{~m}$ & $3.17 \mathrm{E}-01$ & $3.17 \mathrm{E}-01$ & $3.17 \mathrm{E}-01$ \\
\hline$\overline{94}$ & U232 & $2.18 \mathrm{E}-02$ & $2.81 \mathrm{E}-06$ & $4.74 \mathrm{E}-07$ \\
\hline 95 & U233 & $8.71 E-05$ & $3.22 \mathrm{E}-03$ & $2.31 E-02$ \\
\hline 96 & U234 & $1.42 E+00$ & $2.03 E+00$ & $2.01 E+00$ \\
\hline 97 & U235 & $1.72 \mathrm{E}-02$ & $1.75 \mathrm{E}-02$ & $1.87 \mathrm{E}-02$ \\
\hline 98 & U236 & $2.57 \mathrm{E}-01$ & $2.71 E-01$ & $3.17 \mathrm{E}-01$ \\
\hline 99 & U237 & $2.77 \mathrm{E}-01$ & $3.32 E-06$ & $2.39 \mathrm{E}-06$ \\
\hline 100 & U238 & $3.17 \mathrm{E}-01$ & $3.17 \mathrm{E}-01$ & $3.17 E-01$ \\
\hline 101 & Np237 & $3.54 \mathrm{E}-01$ & $9.99 E-01$ & $1.18 \mathrm{E}+00$ \\
\hline 102 & $\frac{1}{\mathrm{Np238}}$ & $2.89 \mathrm{E}-02$ & $3.79 E-04$ & $4.55 \mathrm{E}-12$ \\
\hline 103 & Np239 & $1.70 \mathrm{E}+01$ & $1.56 \mathrm{E}+01$ & $1.07 \mathrm{E}+01$ \\
\hline 104 & Pu236 & $3.76 \mathrm{E} 06$ & $4.86 \mathrm{E}-07$ & $4.74 \mathrm{E}-07$ \\
\hline 105 & $\mathrm{Pu} 237$ & $0.00 \mathrm{E}+00$ & $0.00 \mathrm{E}+00$ & $0.00 \mathrm{E}+00$ \\
\hline$\overline{106}$ & Pu238 & $1.70 \mathrm{E}+03$ & $1.08 \mathrm{E}+00$ & $1.79 E-09$ \\
\hline 107 & Pu239 & $3.13 E+02$ & $3.05 E+02$ & $273 E+02$ \\
\hline 108 & $\mathrm{Pu} 240$ & $5.28 \mathrm{E}+02$ & $4.78 E+02$ & $3.13 \mathrm{E}+02$ \\
\hline 109 & $\mathrm{Pu} 241$ & $1.13 E+04$ & $1.35 \mathrm{E}-01$ & $9.77 \mathrm{E}-02$ \\
\hline 110 & Pu242 & $1.72 \mathrm{E}+00$ & $1.72 \mathrm{E}+00$ & $1.71 \mathrm{E}+00$ \\
\hline 111 & Pu244 & $4.22 \mathrm{E}-07$ & $4.22 \mathrm{E}-07$ & $4.22 \mathrm{E}-07$ \\
\hline 112 & Am241 & $3.71 \mathrm{E}+03$ & $8.93 E+02$ & $1.56 \mathrm{E}+00$ \\
\hline 113 & $\mathrm{Am} 242$ & $5.74 \mathrm{E}+00$ & $7.55 \mathrm{E}-02$ & $9.05 E-10$ \\
\hline 114 & $\mathrm{Am} 242 \mathrm{~m}$ & $5.77 \mathrm{E}+00$ & $7.59 \mathrm{E}-02$ & $9.10 \mathrm{E}-10$ \\
\hline 115 & $\mathrm{Am} 243$ & $1.70 \mathrm{E}+01$ & $1.56 \mathrm{E}+01$ & $1.07 \mathrm{E}+01$ \\
\hline 116 & $\mathrm{Cm} 242$ & $4.75 E+00$ & $6.24 \mathrm{E}-02$ & $7.51 E-10$ \\
\hline 117 & Cm243 & $6.26 \mathrm{E}+00$ & $5.79 \mathrm{E}-10$ & $0.00 \mathrm{E}+00$ \\
\hline 118 & Cm244 & $2.85 E+02$ & $4.23 \mathrm{E}-11$ & $4.22 \mathrm{E}-11$ \\
\hline 119 & $\mathrm{Cm} 245$ & $1.46 \mathrm{E}-01$ & $1.35 \mathrm{E}-01$ & $9.75 \mathrm{E}-02$ \\
\hline 120 & $\mathrm{Cm} 246$ & $3.10 \mathrm{E}-02$ & $2.70 \mathrm{E}-02$ & $1.50 \mathrm{E}-02$ \\
\hline 121 & $\mathrm{Cm} 247$ & $8.42 \mathrm{E}-08$ & $8.42 \mathrm{E}-08$ & $8.42 \mathrm{E}-08$ \\
\hline 122 & $\mathrm{Cm} 248$ & $1.89 \mathrm{E}-07$ & $1.88 \mathrm{E}-07$ & $1.87 \mathrm{E}-07$ \\
\hline
\end{tabular}


Besides gaseous releases, PANDORA-1.1 considers three types of radionuclide behaviors:

(1) Solubility limited - The concentration of each dissolved elemental species is at a maximum value given by the solubility of that species. Both radioactive and stable isotopes of an element must be counted.

(2) Matrix alteration rate limited - The radionuclide is released congruently with the alteration of the waste matrix when it reacts with water. Currently, no limit of solubility is given to this type of radionuclide.

(3) Secular equilibrium - Radionuclides are found in secular equilibrium with their parent radionuclides (i.e., daughter nuclides that decay so rapidly that the activity is equal to the decay rate of their parents into the chains that produce the daughter nuclides). The radionuclide is modeled as present at the same concentration $\left(\mathrm{Ci} / \mathrm{m}^{3}\right)$ as its parent nuclide.

Tablizs 4 through 6 show lists of these three types of radionuclides tracked by PANDORA-1.1. PANDORA-1.1 checks whether the solubility-limited radionuclides are even more limited by the matrix alteration rate. This limit colvld predominate in cases of very high water flux. On the other hand, PANDORA-1.1 does not now accommodate solubility limits for the present matrix-limited category. Such a limit could dominate in very low water flux cases. The model can be revised for this in a future version.

Under secular equilibrium, we are including several actinide-chain radionuclides with half-lives as long as 22 years. This is reasonable for expected cases of slow processes and long time periods.

The units for mobilization rates and for inventories of radionuclides in a mobile form (but still within the waste package geometric boundary) are in terms of fraction of the inventory of those radionuclides in a whole waste package at that current time. Thus radioactive decay and buildup can be accounted for simply by reference to the inventory tables. The modeling of radionuclide concentration 
depends upon whether we assume a bathtub or flow-through groundwater exposure mode. Section 4.4.2 describes each of these groundwater exposure models.

Table 4

Solubility Limited Radionuclides

\begin{tabular}{|c|c|}
\hline No. & Radionuclide \\
\hline 5 & Fe 55 \\
\hline 7 & Ni 59 \\
\hline 8 & Ni 63 \\
\hline 14 & Zr 93 \\
\hline 28 & Sn121m \\
\hline 29 & Sn126 \\
\hline 42 & Pm146 \\
\hline 44 & Sm147 \\
\hline 45 & Sm148 \\
\hline 46 & Sm151 \\
\hline 47 & Eu152 \\
\hline 48 & Eu154 \\
\hline 49 & Eu155 \\
\hline 51 & Ho166m \\
\hline 83 & Th227 \\
\hline 84 & Th228 \\
\hline 85 & Th229 \\
\hline 86 & Th230 \\
\hline 87 & Th231 \\
\hline 88 & Th232 \\
\hline 89 & Th234 \\
\hline 94 & U232 \\
\hline 95 & U233 \\
\hline 96 & U234 \\
\hline 97 & U235 \\
\hline 98 & U236 \\
\hline 99 & U237 \\
\hline 100 & U238 \\
\hline 101 & Np237 \\
\hline 102 & Np238 \\
\hline 103 & Np239 \\
\hline 104 & Pu236 \\
\hline & \\
\hline & \\
\hline 93 & \\
\hline 9 & \\
\hline 9 &
\end{tabular}


Table 4 (continued)

\begin{tabular}{|l|c|}
\hline 105 & Pu237 \\
\hline 106 & Pu238 \\
\hline 107 & Pu239 \\
\hline 108 & Pu240 \\
\hline 109 & Pu241 \\
\hline 110 & Pu242 \\
\hline 111 & Pu244 \\
\hline 112 & Am241 \\
\hline 113 & Am242 \\
\hline 114 & Am242m \\
\hline 115 & Am243 \\
\hline 116 & Cm242 \\
\hline 117 & Cm243 \\
\hline 118 & Cm244 \\
\hline 119 & Cm245 \\
\hline 120 & Cm246 \\
\hline 121 & Cm247 \\
\hline 122 & Cm248 \\
\hline
\end{tabular}

Table 5

Matrix Alteration Rate Limited Radionuclides

\begin{tabular}{|c|c|}
\hline No. & Radionuclide Symbol \\
\hline 2 & C 14 \\
\hline 3 & Cl 36 \\
\hline 4 & Ca 41 \\
\hline 9 & Se 79 \\
\hline 10 & Kr 85 \\
\hline 11 & Rb 87 \\
\hline 12 & Sr 90 \\
\hline 17 & Mo 93 \\
\hline 18 & Tc 99 \\
\hline 19 & Ru106 \\
\hline 21 & Pd107 \\
\hline 23 & Ag108m \\
\hline 25 & Cd113 \\
\hline 30 & Sb125 \\
\hline 34 & I129 \\
\hline 35 & Cs134 \\
\hline
\end{tabular}


Table 5 (continued)

\begin{tabular}{|l|l|}
\hline 36 & Cs135 \\
\hline 37 & Cs137 \\
\hline 79 & $\operatorname{Ra} 26$ \\
\hline
\end{tabular}

Table 6

Radionuclides in Secular Equilibrium with Controlling Parent

\begin{tabular}{|c|c|c|}
\hline No. & Radionuclide & Controlling Parent \\
\hline 13 & $\overline{Y 90}$ & Sr90 \\
\hline 15 & $\mathrm{Nb} 93 \mathrm{~m}$ & $\mathrm{Zr93}$ \\
\hline 20 & Rh106 & Ru106 \\
\hline 22 & Ag108 & Ag108m \\
\hline 31 & Sb126 & Sn126 \\
\hline 32 & Sb126m & Sn126 \\
\hline 33 & Te125m & Sb125 \\
\hline 38 & $\mathrm{Ba} 137 \mathrm{~m}$ & Cs137 \\
\hline 52 & $\mathrm{~T} 1207$ & $\overline{P a 231}$ \\
\hline 53 & T1208 & Th228 \\
\hline 54 & Pb209 & Th229 \\
\hline 55 & Pb210 & Ra226 \\
\hline 56 & Pb211 & $\mathrm{Pa} 231$ \\
\hline 57 & Pb212 & Th228 \\
\hline 58 & Pb214 & Ra226 \\
\hline 59 & $\mathrm{Bi} 210$ & Ra226 \\
\hline 60 & $\mathrm{Bi} 211$ & Pa231 \\
\hline 61 & $\mathrm{Bi212}$ & Th228 \\
\hline 62 & $\mathrm{Bi} 213$ & Th229 \\
\hline 63 & $\mathrm{Bi} 214$ & Ra226 \\
\hline$\overline{64}$ & Po210 & Ra226 \\
\hline 65 & Po212 & Th228 \\
\hline 66 & Po213 & Th229 \\
\hline 67 & Po214 & $\overline{R a 226}$ \\
\hline 68 & Po215 & Pa231 \\
\hline 69 & Po216 & Th228 \\
\hline 70 & Po218 & Ra226 \\
\hline 71 & At217 & Th229 \\
\hline 72 & Rn219 & Pa231 \\
\hline 73 & $\operatorname{Rn} 220$ & Th228 \\
\hline
\end{tabular}


Table 6 (continued)

\begin{tabular}{|c|c|c|}
\hline 74 & Rn222 & Ra226 \\
\hline 75 & Fr221 & Th229 \\
\hline 76 & Ra223 & Pa231 \\
\hline 77 & Ra224 & Th228 \\
\hline 78 & Ra225 & Th229 \\
\hline 80 & Ra228 & Th232 \\
\hline 81 & Ac225 & Th229 \\
\hline 82 & Ac227 & Pa231 \\
\hline 91 & Pa233 & Np236 \\
\hline 92 & Pa234 & U238 \\
\hline 93 & Pa234m & U238 \\
\hline
\end{tabular}

The gas $\mathrm{Kr}-85$ is included in the rate-limited category. Its mobilization from the matrix is limited by the water-based alteration of the matrix. After mobilization, PANDORA-1.1 treats its transport differently because it is a gas.

As the spent fuel matrix is altered, Ra-226 existing at that time is released. Future production of Ra-226 from decay of Th-230 is not tracked. This is a reasonable first approximation. Most of the $T h$ and $U$ in the decay chain leading to Ra-226 is likely to be located in solid secondary minerals and alteration products from the initial $\mathrm{UO}_{2}$-based spent fuel matrix.

PANDORA-1.1 assumes that all the radionuclides in the matrix-alteration-rate limited category have a fraction of their inventory located in the fuel/cladding gap. This fraction can be dissolved upon contact by water. The assumption provides an overestimate for the leading edge of the release rate versus time for some of these radionuclides. A fuel/cladding gap fraction has been observed for some but not all of these radionuclides. Guenther [1991a,b] measured Kr, I, Xe, and Cs in the fuel/cladding gap of PWR and BWR spent fuels. Wilson [1990b] measured an enhanced early release rate of $\mathrm{Sr}, \mathrm{Tc}, \mathrm{I}$, and $\mathrm{Cs}$ in dissolution experiments on split-cladding spent fuel samples. The early release was presumably from the cladding gap and/or fuel grain boundaries. Hirabayashi [1990] measured $\mathrm{Kr}, \mathrm{Sr}, \mathrm{Ru}, \mathrm{Cs}, \mathrm{Ce}, \mathrm{Pm}$, and Eu on the inner surface of a cladding sample. The $\mathrm{Ru}, \mathrm{Ce}, \mathrm{Pm}$, and Eu radioisotopes are of short half-lives or low inventory; therefore, they are not crucial to the waste package evaluation. The 
fission gases $\mathrm{Kr}$ and $\mathrm{Xe}$ have a higher fraction in the cladding gap than do the volatiles I and Cs [Stout, 1990], but PANDORA-1.1 uses one fraction input to apply to all of these radionuclides.

Exhaustion of inventories is not treated exactly for long decay chains of transuranics. The program assumes that releases of members lower in the chain can be calculated neglecting losses of their parent radionuclides. This is a reasonable first approximation for expected environments. The major transuranic elements have fairly low to very low solubilities, and the expected water flux is in a low range. The releases over 10,000 years will be low compared to their total inventory. There are a few possible exceptions to low solubility, but they do not upset the approximation for the following reasons. $\mathrm{Ra}-226$ and $\mathrm{Pa}-231$ are low in their decay chains in the sense that all the lower members have fairly short half lives and are treated as being in sr sular equilibrium with Ra-226 or Pa-231, respectively. Elements higher in atomic number than $\mathrm{Cm}$ have low mass inventories at waste emplacement time compared to other members of the same decay chain.

Several radionuclides are not included in Tables 4 through 6. Several have virtually zero inventory or very short half lives and hence are clearly not of interest. The are assigned to the matrix-alteration-rate limited radionuclides and will show zero releases for times of interest. H-3 and Co-60 are contaminants predominantly located in a crud layer or in the cladding. Nb-94 is an activation product in hardware or cladding. For Pa-231 we don't have any concentration limit information at present. For the latter four radionuclides, at present an arbitrary value (10-5/year) is filled in for their release rate, and analysis is deferred to a future version.

\subsubsection{Groundwater Exposure Scenarios}

The release of radionuclides from the emplacement borehole is dependent primarily upon whether and in what manner groundwater contacts the waste form. There are many possible scenarios for waste package and waste form interaction with groundwater. Lacking any formal scenarios study results, we have made some gross simplifying assumptions in our development of the PANDORA model. These assumptions are most likely conservative; however, 
determination of conservatism in the face of such extensive uncertainty must await a more formal treatment of the scenarios and their consequences, which, in turn, should reveal which scenarios and assumptions constitute the worst case.

Following any loss of containment (i.e., container breach), the PANDORA-1.1 model handles three possible scenarios for waste form interaction with groundwater:

- No contact (dry waste form)

- Continuous contact in a "bathtub" mode

- Continuous contact in a "flow-thru" mode

The time of start of water availability is separate from the breach time and is specified by the user. The fraction of this available water entering the waste package is also specified by the user.

There are other potentially important scenarios for groundwater contact with the waste forms. One of those involves capillary suction of the groundwater out of the tuff borehole wall, through cracks in the container and into or onto the waste form surface. This mode could set up a diffusive transport pathway and leaching of radionuclides from the waste form. We have developed a diffusion release model [Ueng and O'Connell, 1992] for this scenario. It will be implemented as a submodel in a future version of the PANDORA model.

Below, we discuss the model for mobilization of waste form radionuclides under each of the three currently modeled scenarios.

\section{No Groundwater Contact}

In this scenario, the user of the model has specified either a zero groundwater flow rate into the emplacement borehole, or that no fraction of the entrant groundwater enters the waste package. The two cases result in identical releases of radionuclides from the waste form, as modeled in PANDORA-1.1.

Since contact with groundwater is the only way in which the vast majority of inventory radionuclides can be mobilized and transported, this scenario is almost 
certainly the least consequential of the three modeled. This does not mean that the "No Groundwater Contact" scenario is incapable of resulting in significant releases of radionuclides. It is possible for waste forms to release gaseous radionuclides which could escape confinement. In fact, it appears that C-14 releases under this scenario could be problematic enough with respect to regulatory compliance for waste packages that a tesign constraint on the failure rate of containers even after 1,000 years would be set [DOE, 1988, Sec. 8.3.5.10].

Any releases which take place under this scenario will also take place under the bathtub and flow-thru scenarios with timing based on container breach, independent of whether it is before or after the rewetting time. In this sense then, the No Groundwater Contact scenario releases represent a subset of the releases from the Bathtub or Flow-thru scenario releases. For spent fuel, PANDORA-1.1 models only three radionuclides that are released as gases: $\mathrm{H}-3, \mathrm{C}-14$ and $\mathrm{Kr}-85$.

As soon as the container is breached, even when water is not present, there is a rapid (immediate) release of a fraction of the current inventories of $\mathrm{C}-14$ and $\mathrm{Kr}-85$. In PANDORA, the $\mathrm{C}-14$ gaseous rapid release fraction is user-specified. This includes $\mathrm{C}-14$ on the exterior of the cladding. ( $\mathrm{C}-14$ inside the cladding and in the matrix is treated as a water-soluble species.) For $\mathrm{Kr}-85$, the rapid release fraction is the same as the user-specified "rapid-release fraction" defined in the specification for aqueous release mechanisms described under the following sections for the Bathtub and Flow-thru scenarios.

At the first time step following the container failure, the above user-specified fractions of inventories of $\mathrm{C}-14$ and $\mathrm{Kr}-85$ are modeled as being completely released from the waste package. Any additional release of these radionuclides or of any $\mathrm{H}-3$ requires interaction of the spent fuel with water. Since no such interaction occurs in this scenario, the initial releases of C-14 and $\mathrm{Kr}-85$ are the only releases from the waste package for the entire post-closure performance period.

\section{Bathtub Mode}

In this mode of groundwater contact, the waste package develops a breach and acts as a container for groundwater, filling up over time and eventually overflowing as depicted in Figure 5. We assume that no additional failures in the 
container take place during the remainder of the analysis. This assumption may not be conservative because, if a second breach should occur at a point lower than the fill level, part or all of the groundwater, along with a significant portion of the radionuclide inventory in the waste package; could be released in a single year.

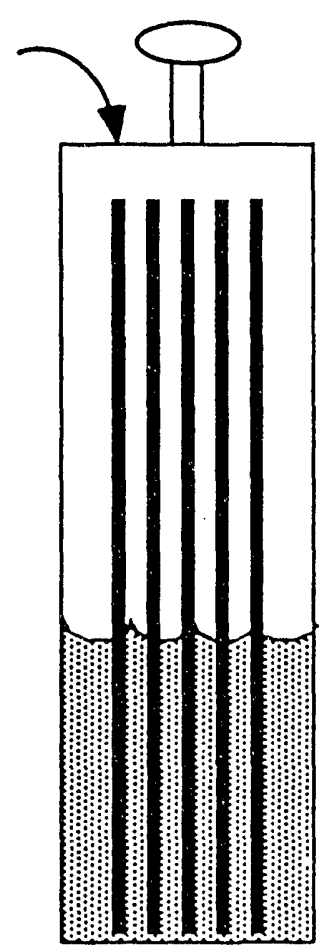

Filling Package

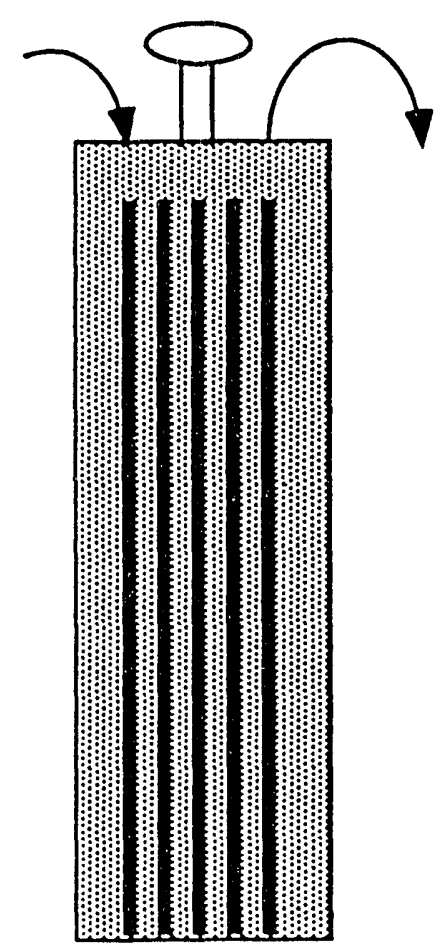

Filled Package

Figure 5. Schematic of the Bathtub Mode of Groundwater Contact

The solution inside the container is assumed well mixed. In order to determine the amount of a radionuclide released from an emplacement borehole during any post-closure year, we need to determine:

1) the quantity of that radionuclide released as gases from a breached waste package during that year,

2) the amount of groundwater flowing out of the emplacement borehole, and 
3) the concentration of that radionuclide in the outflowing groundwater.

As mentioned previously, the decay and buildup of the radionuclides were taken into account in the inventory at various ages. In the calculations, the fraction of the current inventory for a radionuclide is considered instead of moles or curies. Once the fraction of inventory is calculated at any time step, the values in moles or curies can be obtained by multiplying the fraction by the inventory at that age. Therefore, there is no need to include the decay of the radionuclide in calculations. The exhaustion of the inventory due to alteration and release of each radionuclide is also checked at every time step. After the exhaustion of inventory, there is no further release of the radionuclide into groundwater.

\section{Solubility Limited Radionuclides}

The concentration of this type of radionuclide is set equal to the solubility of a radionuclide's elemental species times the fraction of the elemental species that a radionuclide presents in the inventory. The current version of PANDORA does not consider the dependency of the concentration limit on temperature and groundwater chemistry. No rapid release fraction is attributed to this type of radionuclide. The release rate would be limited by the solubility in any case.

After the exhaustion of inventory, the concentration decreases due to additional groundwater inflow and release of the radionuclide through overflowing water out from the container. The concentration becomes

$$
C=C_{o} e^{-f_{\text {out }}\left(t-t_{e}\right) / v_{f}}
$$

where $\mathrm{C}_{\mathrm{o}}=$ solubility of the radionuclide (fraction $/ \mathrm{m}^{3}$ )

$\mathrm{f}_{\text {out }}=$ outflow rate (assumed equal to inflow rate after filling) $\left(\mathrm{m}^{3} / \mathrm{yr}\right)$

$t=$ time since water begins entering the container $(y r)$

$t_{e}=$ time required for inventory exhaustion ( $\left.y r\right)$

$V_{\mathrm{f}}=$ volume of bathtub when filled $\left(\mathrm{m}^{3}\right)$.

For a very high groundwater flow and/or a very low matrix alteration rate, the amount of release of a radionuclide from the matrix may not be sufficient for a 
solution at the solubility limit. Then PANDORA treats this as an alteration rate limited radionuclide.

\section{Matrix Alteration Rate Limited Radionuclides}

These radionuclides have a "rapid-release fraction" (see Section 4.4.1). The permissible range for this input is from 0 to 1 , inclusive. The parameter represents the fraction of a radionuclide that is available for rapid (immediate) release upon contact with water. This input applies to all alteration rate limited radionuclides except $\mathrm{C}-14$, which releases as a gas and whose rapid-release fraction is controlled by another user input described in the specification for gaseous radionuclide releases. Note that, although the "rapid-release fraction" does apply to $\mathrm{Kr}-85$, that radionuclide is also released as a gas and, thus, has zero concentration in the groundwater at any time.

The "annual release fraction" represents the fraction of a radionuclide that is released each year due to the waste-matrix alteration while the fuel is in contact with water. The annual release fraction applies to all of the rate limited radionuclides defined above. It is another user input with permissible range from 0 to 1 . Since we assume it is a constant over time (see Section 2.2), we can describe the release-rate solution analytically.

The time required for the complete inventory exhaustion of a radionuclide after water contact is:

$$
t_{e}=\frac{1-\text { qrapid }}{\text { qannual }}
$$

$$
\begin{gathered}
\text { where } q_{\text {annual }}=\text { annual fractional release of the radionuclide }(1 / \mathrm{yr}) \\
\text { qrapid }=\text { user-specified rapid-release fraction (fraction) }
\end{gathered}
$$

For the bathtub mode, the concentration of a given rate limited radionuclide in the groundwater in the bathtub depends on whether the bathtub is unfilled, or has filled and is now overflowing. It is also affected by the state of inventory exhaustion. 
During filling, i.e., $t \leq t_{f}$, the increase of the amount (in fraction) of the radionuclide in the water inside the container is:

$$
d F(t)=q_{\text {annual }} \frac{f_{\text {in }}}{V_{f}} t d t+q_{\text {rapid }} \frac{f_{\text {in }}}{V_{f}} d t
$$

where $F(t)=$ the amount of radionuclide in the bathtub (fraction)

$f_{\text {in }}=$ groundwater inflow rate (assumed constant after initiation) ( $\left.\mathrm{m}^{3} / \mathrm{yr}\right)$

$\mathrm{f}_{\text {out }}=$ groundwater outflow rate (assumed equal to $\mathrm{f}_{\text {in }}$ after filling)

$$
\left(\mathrm{m}^{3} / \mathrm{yr}\right)
$$

$V_{f}=$ water volume of bathtub when filled $\left(\mathrm{m}^{3}\right)$

$t=$ time since water begins entering the container $(\mathrm{yr})$

$t_{f}=$ time to fill the volume of bathtub $(y r)=V_{f} / f_{\text {in }}$

Integrating with respective to time, we obtain

$$
F(t)=\frac{f_{\text {in }}}{V_{f}}\left(\frac{\text { Gannual } t^{2}}{2}+q_{\text {rapid }} t\right)
$$

After filling, $t>t_{f}$, three conditions are considered relative to $t_{e}$ :

1) Before exhaustion of inventory, $t_{f}<t \leq t_{e}$ :

$d F(t)=$ qannual $d t-\frac{F(t) f_{\text {out }}}{V_{f}} d t$

The solution is

$F(t)=q_{\text {annual }} t_{f}\left[1-\frac{e^{\left(t_{f}-t\right) / t_{f}}}{2}\right]+q_{\text {rapid }} e^{\left(t_{f}-t\right) / t_{f}}$

2) For $t_{e}<t \leq t_{f}+t_{e}$, only part of the spent fuel rods which has an early water contact exhausted their inventory:

$d F(t)=$ qannual $\left[1-\frac{f_{\text {in }}\left(t-t_{e}\right)}{V_{f}}\right] d t-\frac{f_{\text {out }}}{V_{f}} F(t) d t$ 
The solution is

$F(t)=q_{\text {annual }}\left\{\left(2 t_{f}-t+t_{e}\right)-t_{f}\left[1+0.5 e^{-\left(t_{e} e^{\left.-t_{f}\right) / t_{f}}\right.}\right] e^{-\left(t-t_{e}\right) / t_{f}}\right\}+q_{\text {rapid }} e^{-\left(t-t_{f}\right) / t_{f}}$

3) For $t>t_{f}+t_{e}$ :

$d F(t)=-\frac{F(t) f_{\text {out }}}{V_{f}}$, and

$F(t)=q_{\text {annual }} t_{f}\left(1-e^{-1}-0.5 e^{-t_{e} / t_{f}}\right) e^{-\left(t-t_{e}-t_{f}\right) / t_{f}}+q_{\text {rapid }} e^{-\left(t-t_{f}\right) / t_{f}}$

The above relations are for the conditions with the inventory exhaustion time greater than the filling time, i.e., $t_{f}<t_{e}$. If the inventory exhaustion occurs during filling, then the following relations apply after $t>t_{e}$.

1) During filling, $t_{e}<t \leq t_{f}$.

$F(t)=\frac{f_{\text {in }}}{V_{f}}\left[q_{\text {annual }} t_{e}\left(t-t_{e} / 2\right)+q_{\text {rapid }} t\right]$

2) After filling, when $t_{f}<t \leq t_{f}+t_{e}$ :

$F(t)=q_{\text {annual }}\left[2 t_{f}+t_{e}-t-\left(t_{f}+\frac{t_{e}^{2}}{2 t_{f}}\right) e^{-\left(t-t_{f}\right) / t_{f}}\right]+q_{\text {rapid }} e^{-\left(t-t_{f}\right) / t_{f}}$

3) For $t>t_{f}+t_{e}$ :

$F(t)=q_{\text {annual }}\left[t_{f}-\left(t_{f}+\frac{t_{e}^{2}}{2 t_{f}}\right) e^{-t_{e} / t_{f}}\right] e^{-\left(t-t_{f}-t_{e}\right) / t_{f}}+q_{\text {rapid }} e^{-\left(t-t_{f}\right) / t_{f}}$

The concentration of the solution (fraction $/ \mathrm{m}^{3}$ ) in the bathtub is

$C(t)=\frac{F(t)}{f_{\text {in }} t}$, during filling, and 


$$
C(t)=\frac{F(t)}{V_{f}} \text {, after filling. }
$$

\section{Carbon-14}

Following the initial gaseous release from the fuel pin cladding, the rapid and annual releases of C-14 take place as for any other aqueous release radionuclide. Thus, the formulas provided in the specification for aqueous releases are appropriate. We do not currently model potential gaseous releases of C-14 arising from fuel oxidation.

\section{Krypton-85}

Following the initial gaseous release, there is no rapid release of $\mathrm{Kr}$-85, although there is an annual release following the same rates as apply for the non-gaseous releases into solution. However, unlike those nuclides which dissolve into the groundwater and are released along with the groundwater, $\mathrm{Kr}-85$ is assumed to be immediately available for transport upon "dissolution". Therefore, instead of formulas for the concentration of $\mathrm{Kr}-85$, we need formulas for the release during each time step:

$$
\begin{aligned}
& r=I \Delta t \text { qannual } \frac{f_{\text {in }}}{V_{f}}\left(t+\frac{\Delta t}{2}\right) \text { during filling, } \\
& r=I \Delta t \text { qannual after filling, and } \\
& r=0 \text { after the inventory exhausted }
\end{aligned}
$$

where $r=$ total release at current time step (curies)

$I$ = current inventory of a radionuclide (curies)

$\Delta \mathrm{t}=$ time step $(\mathrm{yr})$.

\section{Flow-thru Mode}

In Figure 6, we provide a schematic representation of the flow-thru mode of groundwater contact. In this mode of contact, groundwater enters the waste 
package through a hole which is above the waste form with respect to gravity. The groundwater then flows through the waste package, contacting all or a portion of the waste f:rm before exiting a second hole at the waste package bottom. As the groundwater travels along the length of the waste form surface, it accumulates radionuclides dissolved and released from the waste form and carries them out of the waste package.

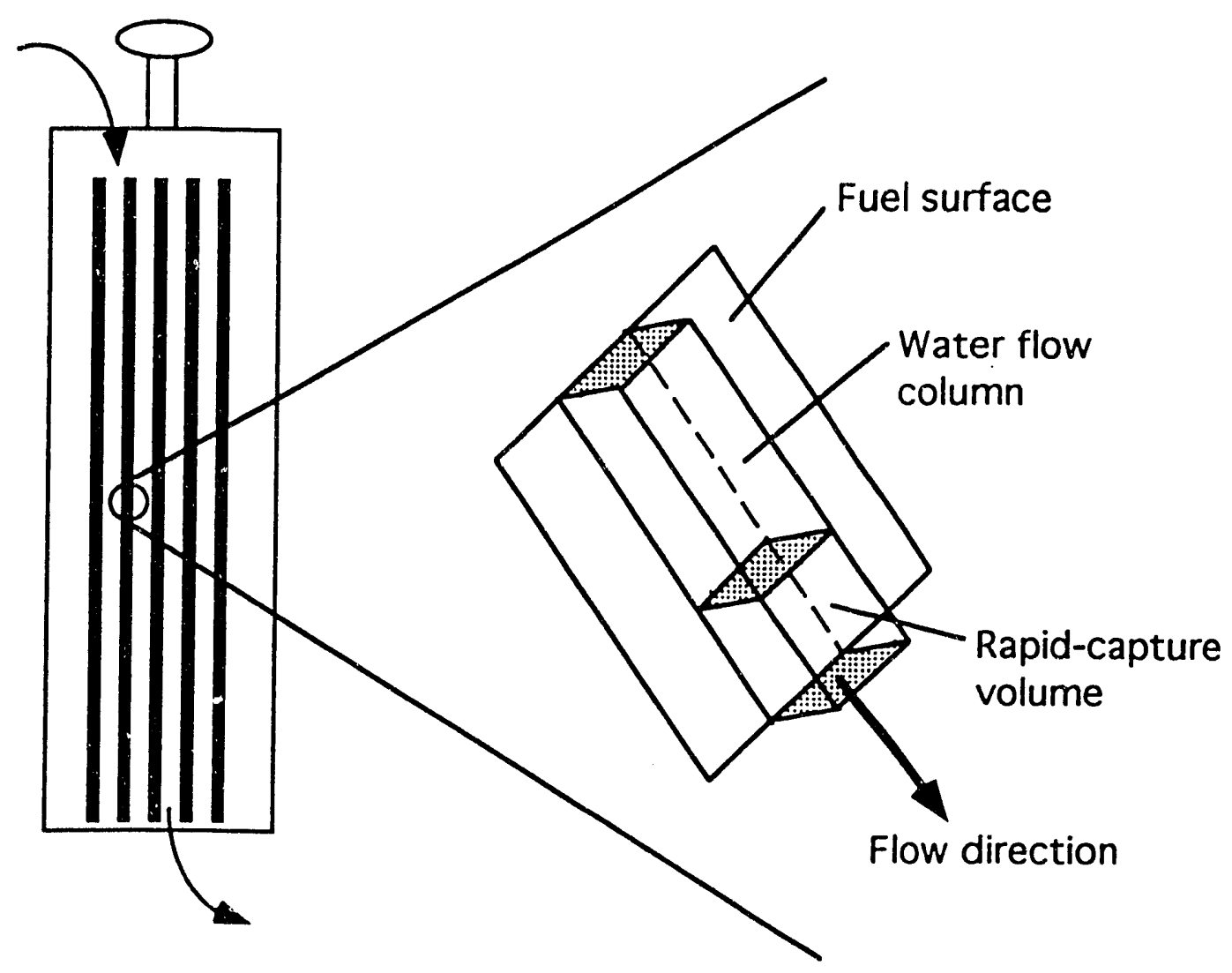

Figure 6. Schematic of the Flow-thru mode of groundwater contact

We are modeling this mode with some simplifying assumptions. First, we assume that the flow-thru path across the fuel surface does not change its surface area, once established. Second, we assume that progress of water through the waste package is constant, which is equivalent to assuming that the volume of water in the flow path is constant along the length of the path. This is the volume of water films on the fuel surface. Third, we assume that no mixing takes place 
within the volume of the flow path, i.e., the concentration of a differential volume of water in the flow path is a function only of the contact of that differential volume with the waste form; its concentration is not affected by the concentration of adjacent water in the flow path. Lastly, we assume that the rapid-release fraction is removed from the wetted fuel surface over a finite period of time, rather than entirely into the first differential volume of water which contacts the fuel. The volume of water that absorbs the rapid-release fraction is specified by the user.

Given this model, the user input quantities "rapid-release fraction" and "annual release fraction" are still relevant (although the input values may be different than those for the bathtub mode). However, because of the uncertainties regarding the portion of fuel which contacts the groundwater in this mode, additional inputs are required.

The first additional user input required is the "flow-thru areal fraction", which is the fraction of the spent fuel surface that contacts the flowing groundwater once the process reaches a steady state (i.e., after an initial flow-in-but-no-flow-out-yet period). It is dimensionless and has a range of 0 to 1 , inclusive. We assume that the "flow-thru areal fraction" remains constant until the inventory of the radionuclide in the whole waste package is exhausted. That is, the wetted surface area may spread to other parts of fuel rods when the inventory of the initial wetted portion is exhausted. The rapid release is the "rapid release fraction" times the "flow-thru areal fraction". We assume that the balance of the "rapid release fraction" is released gradually along with the matrix-bound fraction.

The second additional input required is the "flow-thru volume", which quantifies the volume of groundwater in the waste package once a steady-state has been achieved.

The last additional input quantity needed is the "rapid-release capture volume", which defines the volume of the groundwater front that absorbs the rapid-release fraction. Each of the last two inputs may have any positive value.

\section{Solubility Limited Radionuclides}


As in the bathtub mode, a rapid release of this type of radionuclides is not considered.

Before inventory exhaustion, the concentration of the radionuclide is equal to the solubility of the radionuclide's element species times the fraction of the elemental species that a radionuclides presents in the inventory. After the exhaustion of the total inventory in the waste package, the concentration is zero.

When the flow rate is very high, the release of a radionuclide due to the matrixalteration may not be sufficient to reach the solubility limit. Then this radionuclide becomes an alteration-rate limited radionuclide.

\section{Matrix Alteration Rate Limited Radionuclides}

Let

$V_{\mathrm{f}}=$ the flow-thru volume (analogous to the void volume for bathtub) $\left(\mathrm{m}^{3}\right)$

$V_{\text {capture }}=$ the rapid-release capture volume for the first flow-thru areal fraction $\left(\mathrm{m}^{3}\right)$

$A_{\mathrm{f}}=$ the flow-thru areal fraction (dimensionless)

$\mathrm{f}_{\mathrm{in}}=$ the rate of groundwater in-flow $=$ out-flow rate for a steady state $\left(\mathrm{m}^{3} / \mathrm{yr}\right)$

$t=$ time since water begins entering the container $(y r)$

$t_{\text {out }}=$ the time water begins exiting the waste package $=\Delta t_{\text {transit }}(y r)$

$\Delta t_{\text {transit }}=V_{\mathrm{f}} / \mathrm{f}_{\text {in }}(\mathrm{yr})$

$\Delta t_{\text {rapid }}=$ the time for the rapid-release fraction to be carried out $=V_{\text {capture }} / f_{\text {in }}(y r)$

The time of exhaustion of the inventory in a specified fraction is $t_{e}=\left(1-q_{r a p i d}\right) / q_{\text {annual }}$, and the time for complete exhaustion of the total inventory in the package is $t_{e} / A_{f}$.

Therefore, the time when $100 \%$ of the radionuclide inventory leaves the container is $\left(t_{e} / A_{f}\right)+t_{\text {out }}$.

The concentration of radionuclides in the outflowing groundwater is dependent upon the release conditions of the rapid-release fraction. For the first userspecified flow-thru areal fraction, the rapid-release fraction will be flushed out in the user-specified rapid-release capture volume. Flushing is completed when the user-specified rapid-release capture volume has exited the waste package, which occurs at a time $\Delta t_{\text {rapid }}$ after the water first begins to exit the waste package. 
Afterwards, the rapid release due to spreading of wetted area will be distributed uniformly over the time period between the completion of flushing and the wetting of the total fuel rod surface area.

While flushing is in progress, i.e., $t_{\text {out }}<t \leq t_{\text {out }}+\Delta t_{\text {rapid, }}$ the concentration is:

$$
C(t)=\frac{A_{f} q_{\text {rapid }}}{V_{\text {capture }}}+\frac{A_{f} q_{\text {annual }}}{f_{\text {in }}}
$$

For $t_{\text {out }}+\Delta t_{\text {rapid }}<t \leq t_{\text {out }}+\left(t_{e} / A_{f}\right)-t_{e}$

$$
C(t)=\frac{\left(1-A_{f}\right) q_{\text {rapid }}}{f_{\text {in }}\left(t_{e} / A_{f}-t_{e}\right)-V_{\text {capture }}}+\frac{A_{f} q_{\text {annual }}}{f_{\text {in }}}
$$

For $t_{\text {out }}+\left(t_{e} / A_{f}\right)-t_{e}<t \leq t_{\text {out }}+\left(t_{e} / A_{f}\right)$

$$
C(t)=\frac{A_{f} q_{\text {annual }}}{f_{\text {in }}}
$$

For $t>t_{\text {out }}+t_{e} / A_{f}$

$$
C(t)=0
$$

\section{Release of Gaseous Radionuclides}

Krypton- 85 is assumed to be released as a gas and have zero concentration in the groundwater contacting the waste form. Instead, any amounts of $\mathrm{Kr}-85$ released from the waste form are immediately available for transport. Carbon-14, however, is soluble in groundwater and is not immediately available for transport, except for the initial gaseous release on contact with air.

For this mode, the release of $\mathrm{Kr}-85$ in a time step is given by:

Before water begins to exit the waste package, i.e., $t<t_{\text {out }}$ 


$$
r=I A_{f} q_{\text {annual }} \Delta t\left(\frac{t}{t_{\text {out }}}+\frac{\Delta t}{2 t_{\text {out }}}\right)
$$

where $\mathrm{r}=$ total release at current time step (curies)

$\mathrm{I}=$ current inventory of a radionuclide (curies)

$\Delta \mathrm{t}=$ time step $(\mathrm{yr})$

After water begins to exit the waste package, i.e., $t_{\text {out }} \leq t<\left(t_{e} / A_{f}\right)$,

$$
r=I A_{f} q_{\text {annual }} \Delta t
$$

After inventory exhaustion, $t \geq t_{e} / A_{f}$,

$$
r=0
$$

\subsection{Waste Transport}

In this model, radionuclides are released, in units of curies/yr, either as free gases or as solutes in the outflowing groundwater. The total cumulative release of each rationuclide is also computed for the user-specified time period of analysis.

\subsubsection{Groundwater Transport}

In the current version of PANDORA, releases from the EBS take place at the borehole surface; as soon as groundwater flows out of the borehole, any dissolved radionuclides are considered to be released from the EBS.

The volume and status of inflowing groundwater is modeled within the environmental submodel, while the flow and retention of water within the waste package is modeled within the waste form alteration submodel. There is an assumption in the transport model that there is an advective flow of water through the borehole without holdup in the borehole. This assumption may not be true in some cases, perhaps due to the effects of deposit accumulation on the borehole surface or perhaps due to a fracture terminating in the upper portion of a borehole and permitting fracture flow into the borehole with no means of exit. 
Mechanisms that could lead to such retention of groundwater within the borehole will be examined in the future both with regard to causes and consequences of such a scenario.

Because the borehole retains no water, the volume and character of outflowing groundwater is the result of water flowing around the waste package and of water flowing in and out of the waste package. The confluence of these two streams results in the final volume and character of outflowing groundwater. However, the transport submodel is currently concerned only with radionuclide releases; consequently, the output of the transport model is the set of radionuclide release rates from the borehole, which are, in turn, determined entirely by the groundwater flowing from the waste package, along with any gaseous releases.

\subsubsection{Transport of Gaseous Radionuclides}

Presently, the transport model for gaseous radionuclides is extremely simple and probably conservative. We currently assume that gaseous radionuclides are released from the engineered barrier system as soon as they exit the waste package. Since gaseous nuclides are assumed to exit the waste package immediately after being released from the waste forms, we have a zero transport time from waste form to outside the EBS.

\subsection{Comparison with NRC Criteria}

To analyze the performance of the waste package, the maximum release rates during the computation period as fractions of the 1000-yea- inventory of the radionuclides are compared with the NRC release rate criteria on the EBS [10 CFR 60] as described in Section 3. Their maximum release rates and the times of occurrence are given. The radionuclides with maximum release rates higher than the NRC requirements are also identified. Such a rate is not in itself a violation of the NRC performance requirement, since we are analyzing a single waste package, and the NRC requirement applies to the set of all the waste packages. 


\section{EXA: :APLES}

Preliminary calculations of release rates of Tc-99, I-129, Cs-135, and Np-237 from spent fuel in a potential repository in tuff were conducted using PANDORA-1.1 as part of the efforts of the performance assessment Working Group 2 to provide the source term information to performance assessment Working Group 1 for a preliminary assessment of total system performance [Apted, et al., 1990]. The dimensions and fuel loading of the waste package and the hydrological properties used in the these calculations are given in Table 7.

Table 7

Dimensions and Fuel Loading of Waste Package and Hydrological Properties

\begin{tabular}{|l|r|}
\hline Waste Package Height & $4.6 \mathrm{~m}$ \\
\hline Waste Package Outside Diameter & $0.71 \mathrm{~m}$ \\
\hline Waste Package Overall Volume & $1.73 \mathrm{~m}^{3}$ \\
\hline Waste Package Internal Void Volume & $1.22 \mathrm{~m}^{3}$ \\
\hline Waste Package Content & $2.1 \mathrm{MTIHM}$ \\
\hline Surface Area of fuel rods & $140 \mathrm{~m}^{2}$ \\
\hline Far-field Average Darcy Velocity of Groundwater & $0.5 \mathrm{~mm} / \mathrm{yr}$ \\
\hline Water Flux onto Waste Package & $1 \mathrm{~L} / \mathrm{yr}$ \\
\hline Wetted Fraction of Fuel Rods in the Flow-thru Mode & 0.2 \\
\hline Travel Time in Waste Package in the Flow-thru Mode & $50 \mathrm{yr}$ \\
\hline
\end{tabular}

The time-dependent release rates of Tc-99, I-129, Cs-135, and Np-237 for the bathtub mode and flow-thru mode are shown in Figures 7 and 8 , respectively. The plots are based on the numerical output from PANDORA-1.1. The output files are included in the Appendix. Note that the input data file used for this calculation is echoed at the end of the output. The external data tables of inventories and solubilities are not listed. The inventory tables are as in Table 3 in Section 4.4 .1 but have more time points. The solubility value used for Np-237 is $1.26 \times 10^{-6}$ moles $/ \mathrm{m}^{3}$ as discussed by Apted, et al. [1990]. 


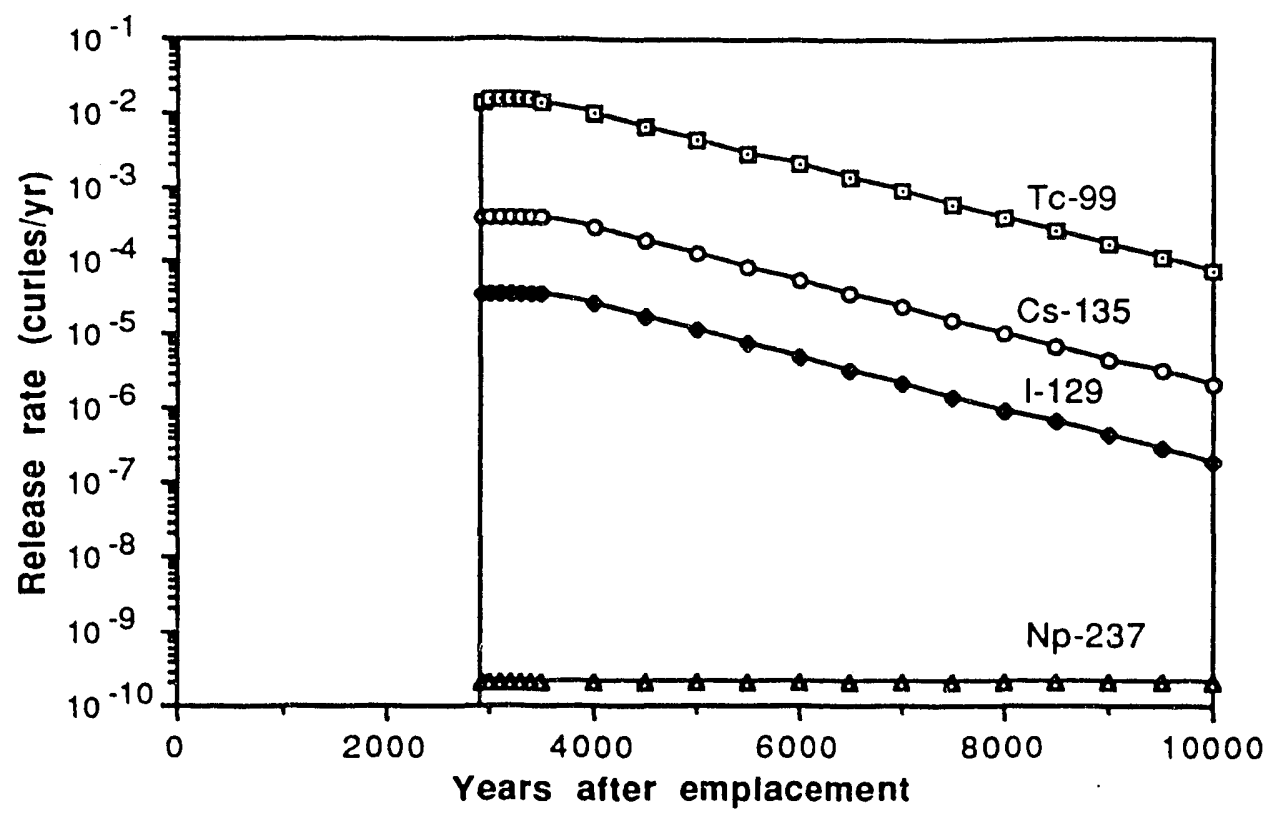

Figure 7. Release Rate from a Single Waste Package, Bathtub Mode

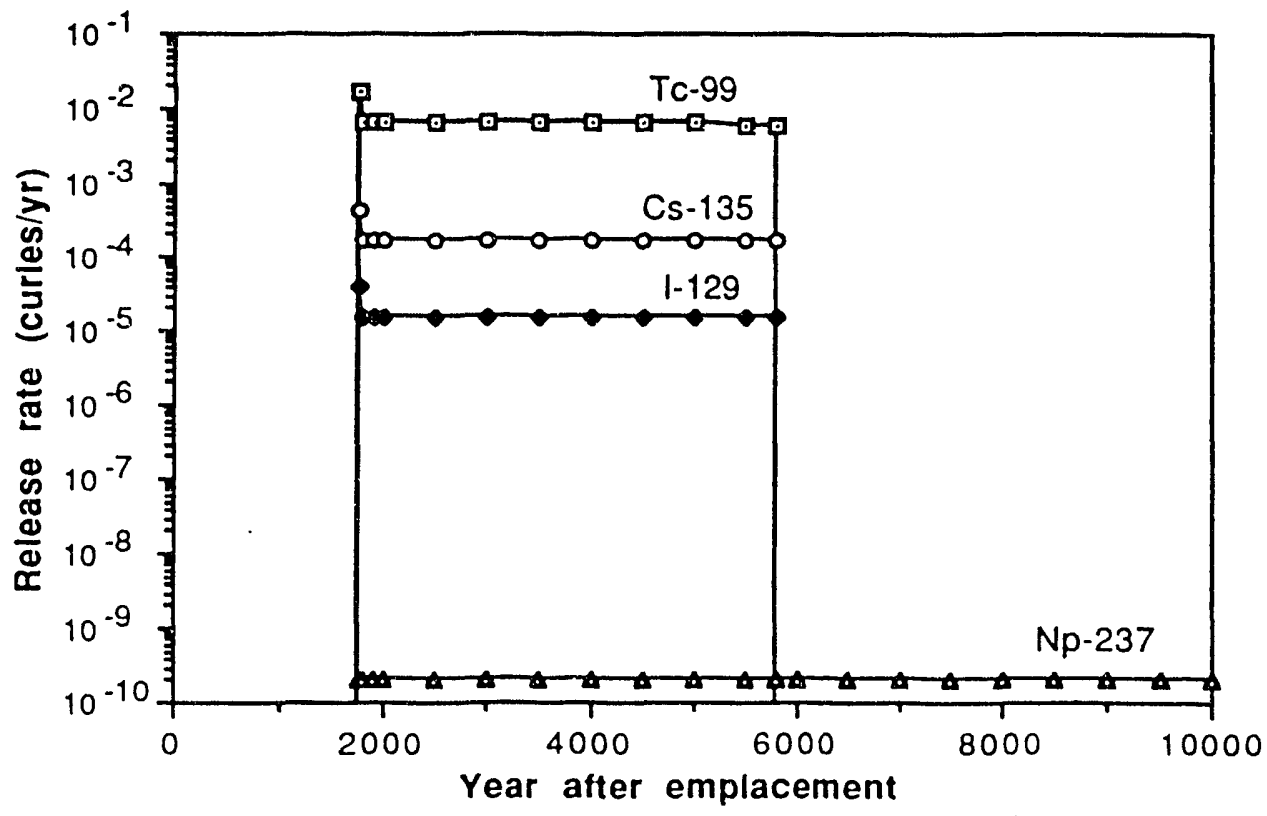

Figure 8. Release Rate from a Single Waste Package, Flow-thru Mode 


\section{ACKNOWLEDGMENTS}

The report and the current PANDORA-1.1 program are based in part on earlier work by D. Lappa and C. Hardenbrook. That was not published at the time, as mentioned above at the end of Section 3. It was, however, briefly described by O'Connell, Lappa, and Thatcher [1989] and example results were presented [O'Connell, 1990]. The program and report have been extensively modified, but they build on the earlier foundation to which the authors are indebted.

\section{REFERENCES}

Apted, M.J., W.J. O'Connell, K.H. Lee, A.T. MacIntyre, T.-S. Ueng, W. W.-L. Lee, and T.H. Pigford, 1990. Preliminary Calculations of Release Rates of Tc-99, I-129, Cs135, and Np-237 from Spent Fuel in a Potential Repository in Tuff, LBL-31069, Lawrence Berkeley Laboratory, Berkeley, CA. NNA.900627.0053

Apted, M.J., W.J. O'Connell, K.H. Lee, A.T. Macintyre, T.-S. Ueng, T.H. Pigford, and W. W.-L. Lee, 1991. "Preliminary Calculations of Release Rates from Spent Fuel in a Tuff Repository," IHLRWM Conf., April 1991, p. 1080, also UCRL-JC104832, Lawrence Livermore National Laboratory, Livermore, CA.

NNA.920121.0011

Barnard, R.W., and H.A. Dockery (eds.), 1991. Technical Summary of the Performance Assessment Calculational Exercises for 1990 (PACE-90), Volume 1: "Nominal Configuration" Hydrogeologic Parameters and Calculational Results, SAND90-2726, Sandia National Laboratories, Albuquerque, N.M. NNA.910523.0001

Barnard, R.W., M.L. Wilson, H.A. Dockery, J.H. Gauthier, P.G. Kaplan, R.R. Eaton, F.W. Bingham, and T.H. Robey, 1992. TSPA 1991: An Initial Total-System Performance Assessment for Yucca Mountain, SAND91-2795, Sandia National Laboratories, Albuquerque, N.M. (Readily Available)

Buscheck, T. A., J. J. Nitao,, and D. A. Chesnut, 1991. "The Impact of Episodic Nonequilibrium Fracture-Matrix Flow on Geologic Repository Performance," 
Proc., Nuclear Waste Packaging, FOCUS '91,Sept. 29 - Oct. 2, 1991, Las Vegas, NV, p. 312, American Nuclear Society, La Grange Park, IL, 1992; also UCRL-JC-106759, Lawrence Livermore National Laboratory, Livermore, CA, October 1991. NNA.911231.0023

Farmer, J. C., and R. D. McCright, 1988. "A Review of Models Relevant to the Prediction of Performance of High-Level Radioactive Waste Disposal Containers," Proc. of National Association of Corrosion Engineers Conference, New Orleans, LA, April 17-21, 1989, Paper 519, also UCRL-100172, Lawrence Livermore National Laboratory, Livermore, CA, Nov. 1988. NNA.900723.0218

Gauthier, J. H., M. L. Wilson, and F. C. Lauffer, 1992. "Estimating the Consequences of Significant Fracture Flow at Yucca Mountain," IHLRWM Conf., April 1992, p. 891. NNA.920505.0068

Guenther, R.J., D.E. Blahnik, U.P. Jenquin, J.E. Mendel, L.E. Thomas, and C.K. Thornhill, 1991a. Characterization of Spent Fuel Approved Testing Material - ATM104, PNL-5109-104, Pacific Northwest Laboratory, Richland WA, December 1991. NNA. 911115.0020

Guenther, R.J., D.E. Blahnik, T.K. Campbell, U.P. Jenquin, J.E. Mendel, L.E. Thomas, and C.K. Thornhill, 1991b. Characterization of Spent Fuel Approved Testing Material -- ATM-105, PNL-5109-105, Pacific Northwest Laboratory, Richland WA, December 1991. NNA.911120.0001

Harrison-Giesler, D. J. and R. P. Morissette, 1991. "Summary of Yucca Mountain Engineered Barrier System Concepts Workshop," Proc., Nuclear Waste Packaging, FOCUS '91,Sept. 29 - Oct. 2, 1991, Las Vegas, NV, p. 103, American Nuclear Society, La Grange Park, IL, 1992. NNA

Hirabayashi, T., T. Sato, C. Sagawa, N.M. Masaki, M. Saeki, and T. Adachi, 1990. J. Nucl. Materials 174, p. 45. (Readily Available)

LLNL, 1988. Survey of Degradation Modes of Candidate Materials for High-Level Radioactive Waste Disposal Containers, UCID-21362, Lawrence Livermore National 
Laboratory, Livermore, CA, 8 Volumes. NNA.891222.0305 through NNA.891222.0313

Nitao, J., 1988. Numerical Modeling of the Thermal and Hydrological Environment around a Nuclear Waste Package using the Equivalent Continuum Approximation: Horizontal Emplacement, UCID-21444, Lawrence Livermore National Laboratory, Livermore, CA. NNA.890317.0021

O'Connell, W. J. and R. S. Drach, 1986. Waste Package Performance Assessment: Deterministic System Model program Scope and Specification, UCRL-53761, Lawrence Livermore National Laboratory, Livermore, CA. NNA.870813.0108

O'Connell, W. J., 1990. "Status of Integrated Performance Assessment of the Waste Packages and Engineered Barrier System," IHLRWM Conf., April 1990, p. 380, also UCRL-102114, Lawrence Livermore National Laboratory, Livermore, CA. NNA.900607.0215

O'Connell, W. J., D. A. Lappa, and R. M. Thatcher, 1989. "Waste Package Performance Assessment for the Yucca Mountain Project," Waste Management '89, University of Arizona, Tucson, AZ, V. 1, p. 551, also UCRL-100395, Lawrence Livermore National Laboratory, Livermore, CA. NNA.890912.0065

Pigford, T. H., P. L. Chambre, and W. W.-L. Lee, 1990. A Review of Near-Field Mass Transfer in Geologic Disposal Systems, LBL-27045, Lawrence Berkeley Laboratory, Berkeley, CA. NNA.920121.0009

Short, D. W., D. J. Ruffner, and L. J. Jardine, 1991. "Engineered Barrier System and Waste Package Design Concepts for a Potential Geologic Repository and Yucca Mountain," Proc., Nuclear Waste Packaging, FOCUS '91,Sept. 29 - Oct. 2, 1991, Las Vegas, NV, p. 113, American Nuclear Society, La Grange Park, IL, 1992. NNA.930419.0099

Smith, H.D., and D.L. Baldwin, 1989. "An Investigation of Thermal Release of ${ }^{14} \mathrm{C}$ from PWR Spent Fuel Cladding", FOCUS'89 (American Nuclear Society), p. 46. NNA.911212.0183 
Stout, R. B., 1990. "Spent Fuel Characteristics Overview," presented to Nuclear Waste Technical Review Board, August 1990; also as p. 2.1.3.4-4 of Preliminary Waste Form Characteristics Report, R. B. Stout and H. Leider, editors, 1991 (in review).

U. S. Department of Energy (DOE), 1987. Characteristics of Spent Fuel, High-Level Waste, and Other Radioactive Wastes Which May Require Long-Term Isolation, DOE/RW-0184, Washington, D. C. NN1.880803.0009

U. S. Department of Energy (DOE), 1988. Site Characterization Plan, Yucca Mountain Site, Nevada Research and Development Area, Nevada, DOE/RW-0199, 9 volumes, Office of Civilian Radioactive Waste Manageinent, Washington, DC, December 1988. HQO.881201.0002

U. S. Nuclear Regulatory Commission, 1991. Title 10, Code of Federal Regulations, Part 60, "Disposal of High-Level Radioactive Wastes in Geologic Repositories," Washington, D. C. (Readily Available)

Ueng, T. S. and W. J. O'Connell, 1992. Diffusion Releases Through One and Two Finite Planar Zones From a Nuclear Waste Package, UCRL-ID-109215, Lawrence Livermore National Laboratory, Livermore, CA. NNA.920622.0077

Van Konynenburg, R. A., 1991. "Gaseous Release of C-14: Why the High Level Waste Regulations Should Be Changed," IHLRWM Conf., April 28-May 2, 1991, p. 313, also UCRL-JC-104763, Lawrence Livermore National Laboratory, Livermore, CA. NNA.920413.0140

Wilson C.N., 1990a. Results from NNWSI Series 2 Bare Fuel Dissolution Tests, PNL7169, Pacific Northwest Laboratory, Richland WA, September 1990.

NNA. 900814.0048

Wilson, C.N., 1990b. Results from NNWSI Series 3 Spent Fuel Dissolution Tests, PNL-7170, Pacific Northwest Laboratory, Richland WA, June 1990.

NNA. 900329.0142 
Wilson, C. N. and C. J. Bruton, 1989. "Studies on Spent Fuel Dissolution Behavior under Yucca Mountain Repository Conditions," presented at American Ceramic Society Annual Meeting, Indianapolis, Indiana, April 1989; Report UCRL-100223, Lawrence Livermore National Laboratory, Livermore, CA, 1989.

NNA.900112.0111 
APPENDIX

Output files of examples. 
BATHTUB MODE 


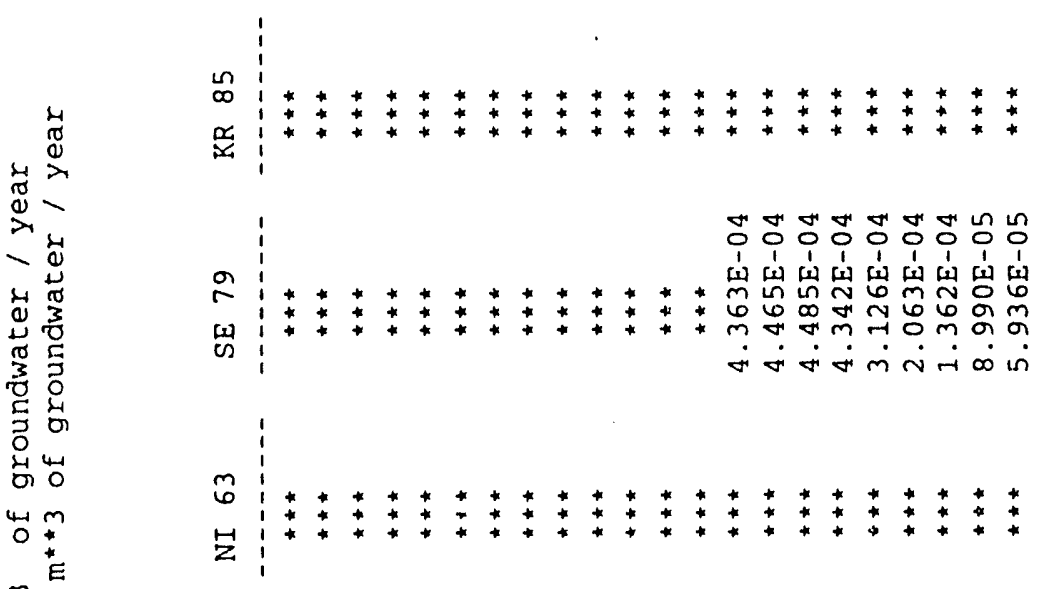




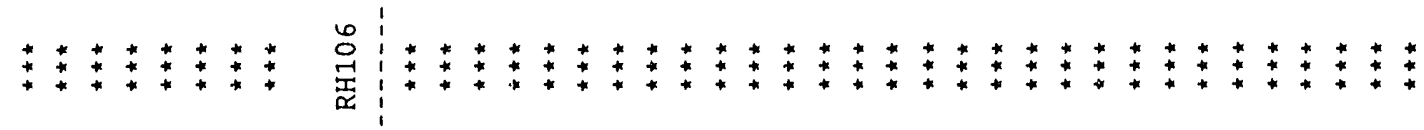

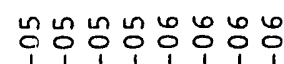

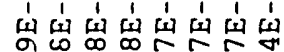
क人 $\dot{m} \dot{\sim} \dot{\sim} \dot{\sim} \dot{\sim} \dot{m} \dot{\sim}$

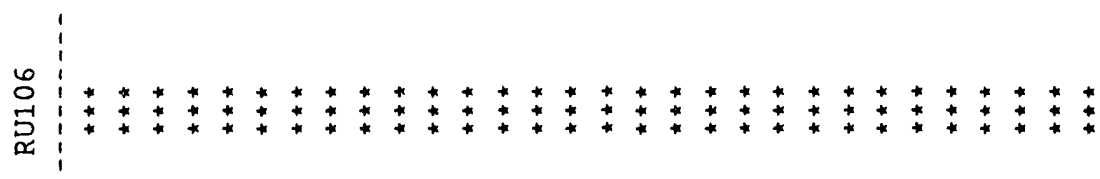

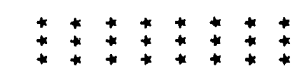

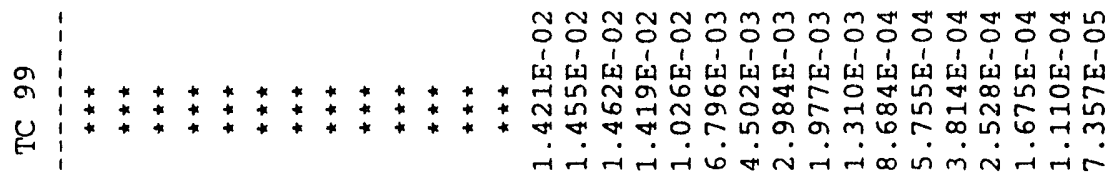

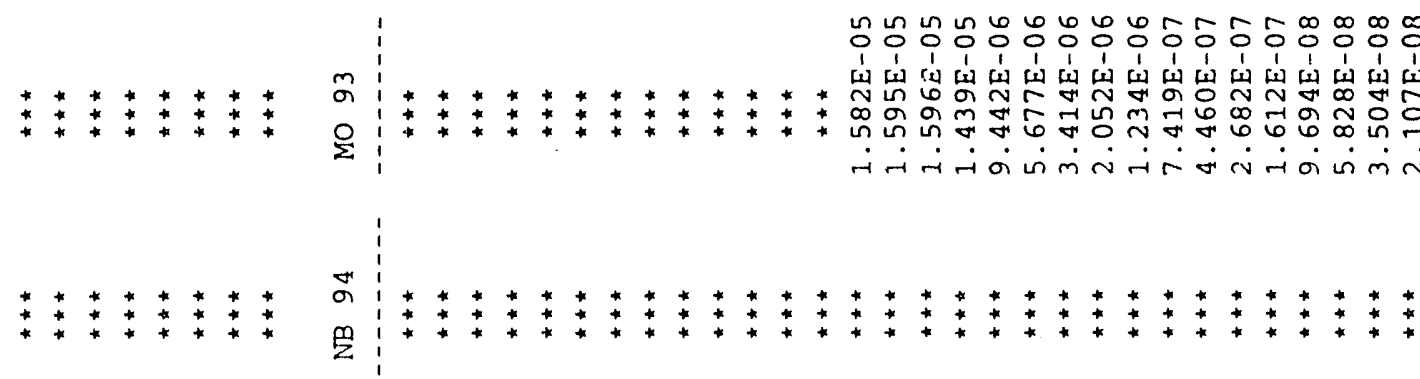

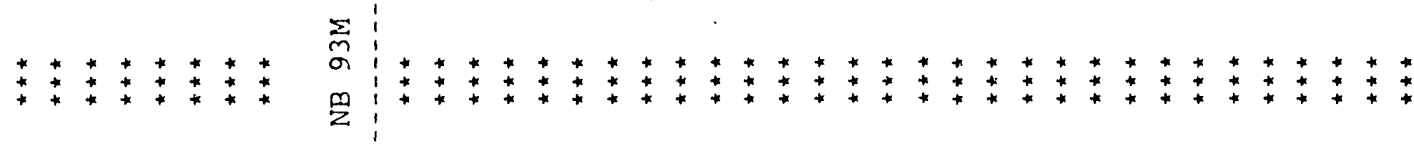
웅영영옹용

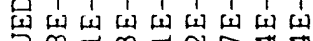

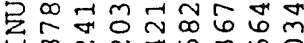

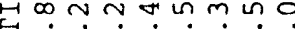

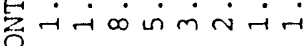

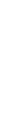

- 응응ㅇㅇㅇㅇㅇ

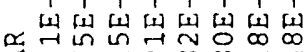

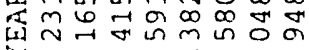
جن 舀

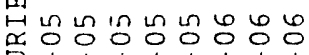

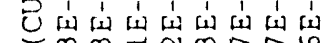

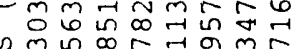
un $m$ in

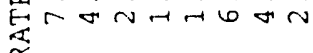

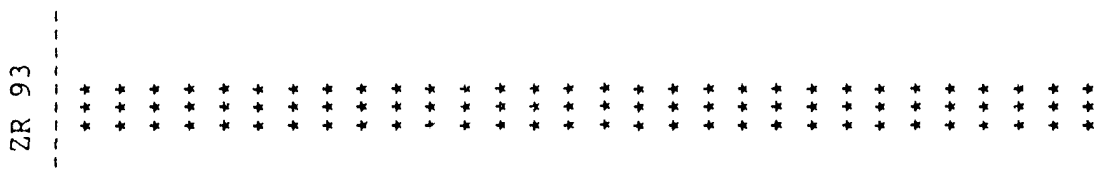

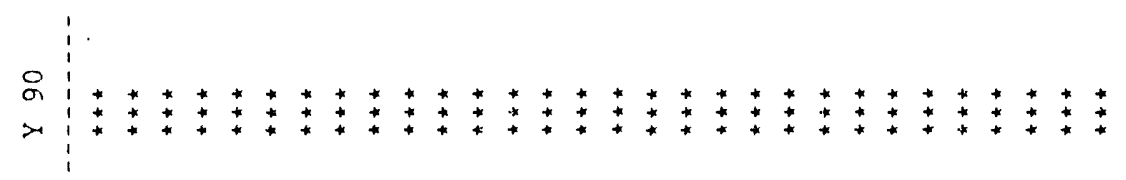
约

舀:

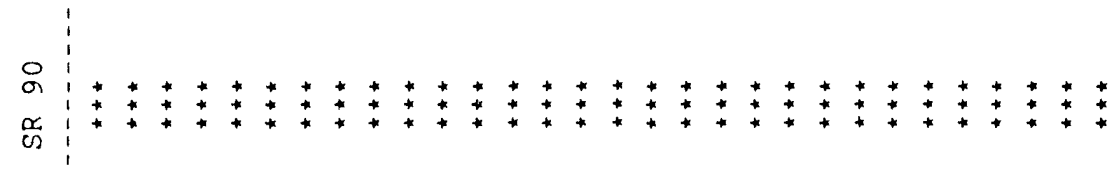

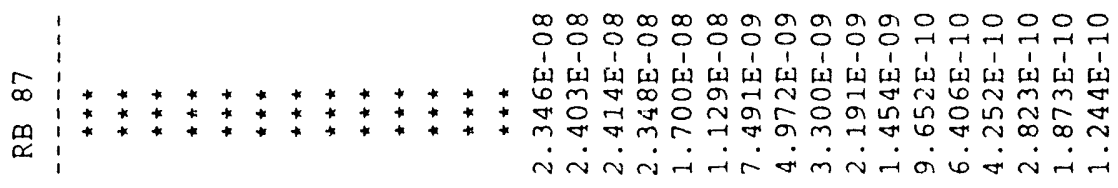
㟔

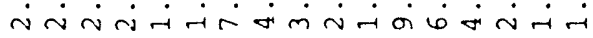

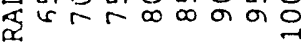

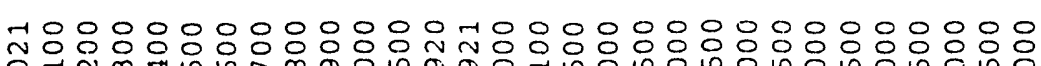

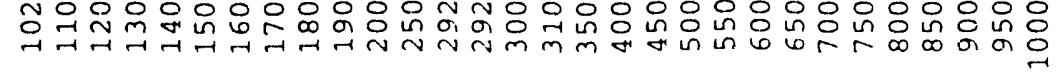


兽

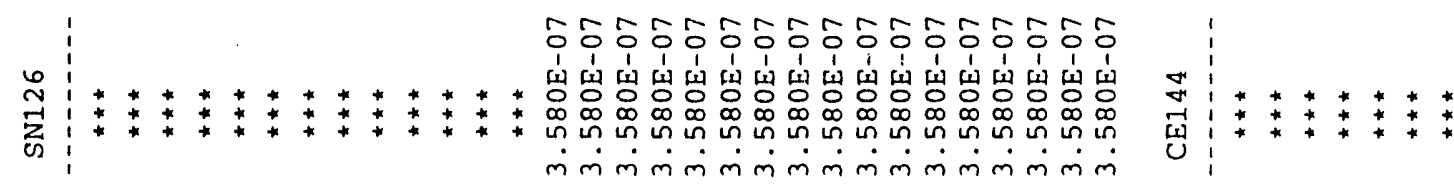
究 究 究 总 \begin{tabular}{l|l}
0 \\
\hline
\end{tabular} 萝总

西

荌象

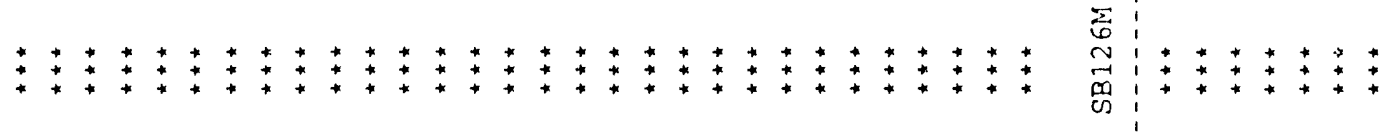

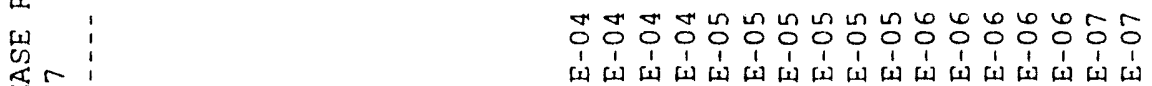

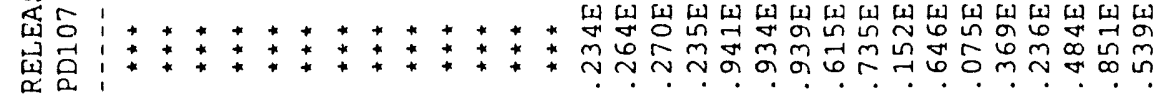
㟔

त- - -

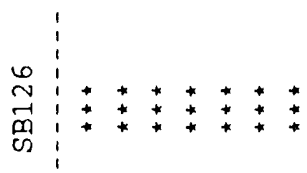

\section{岂哥雚:}

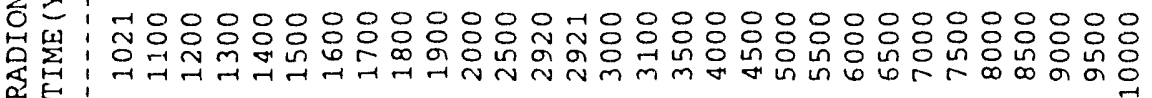

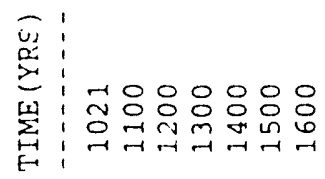




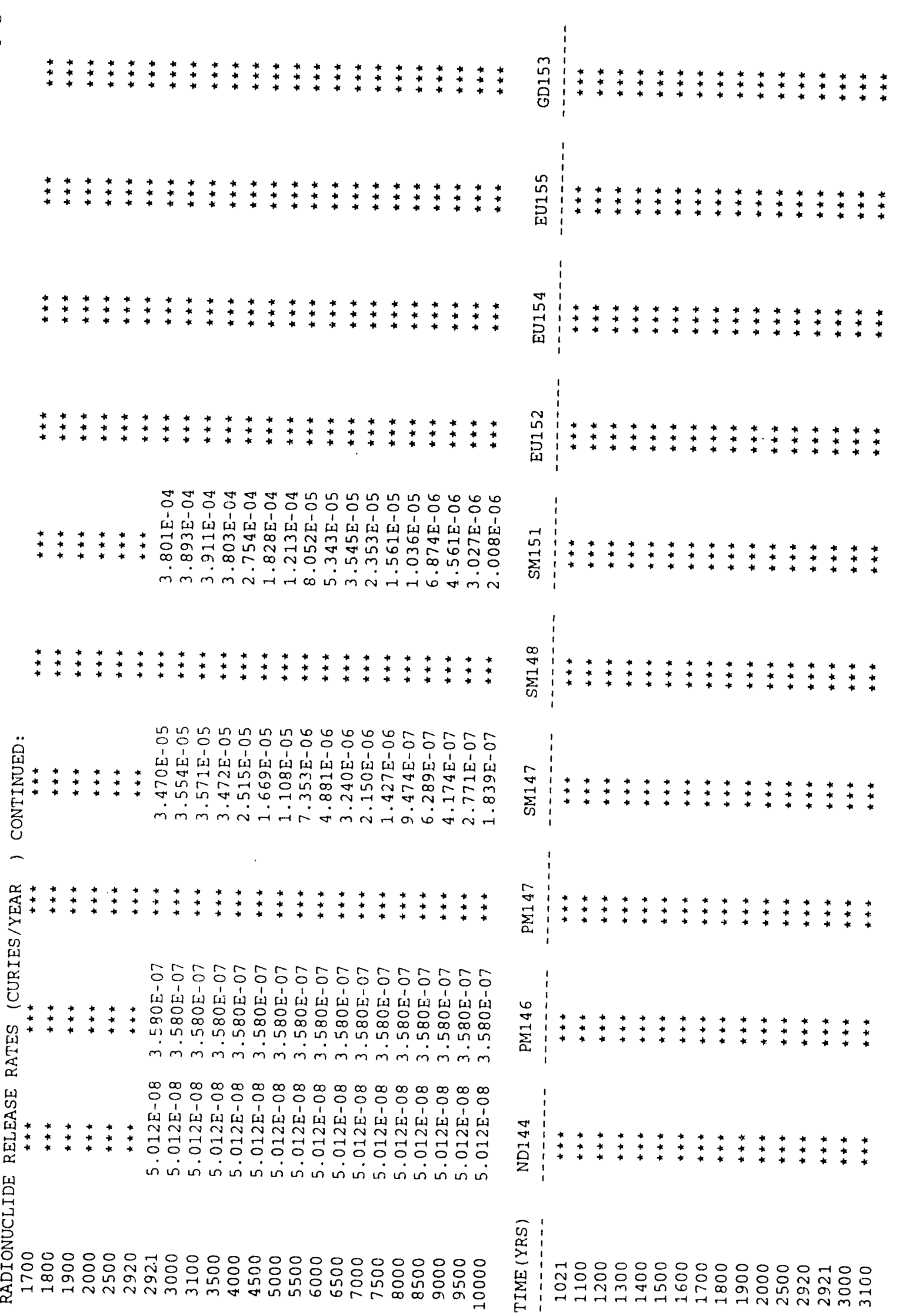


:

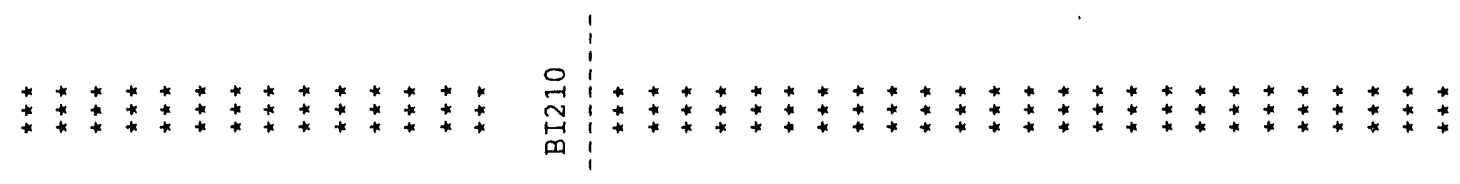

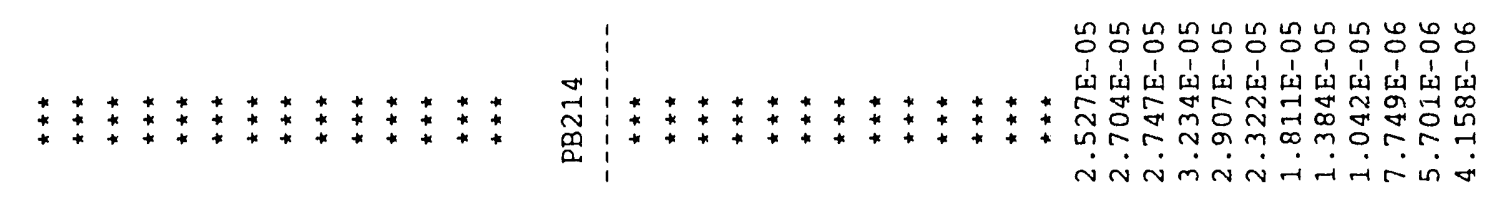

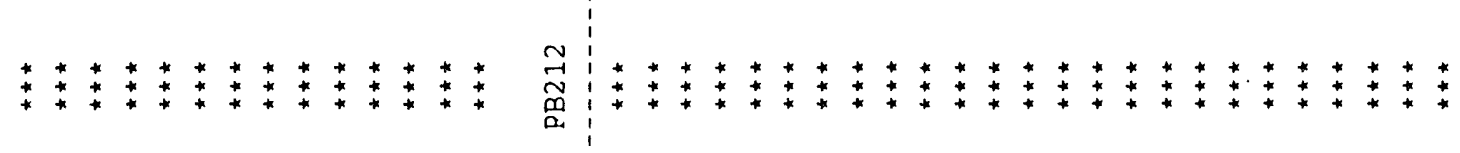

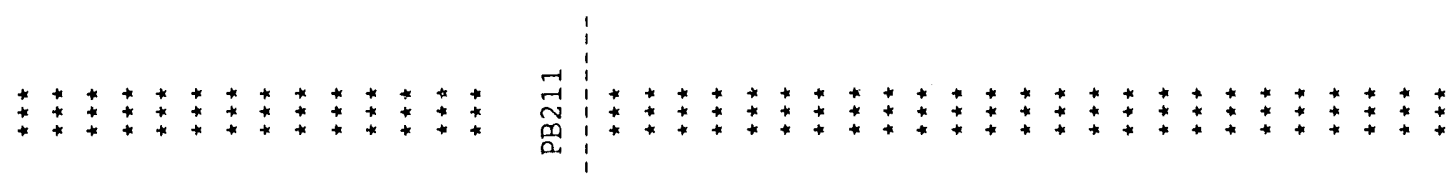

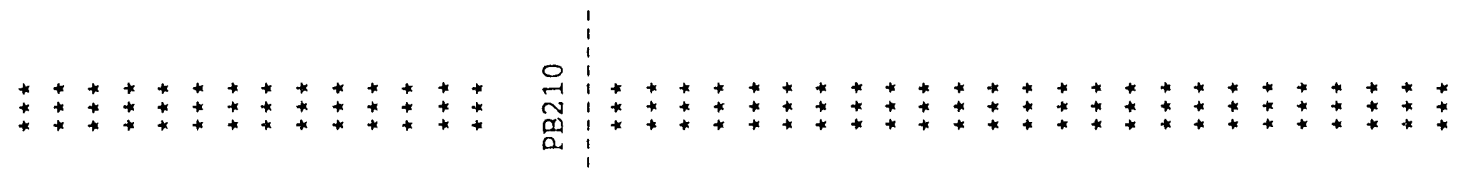

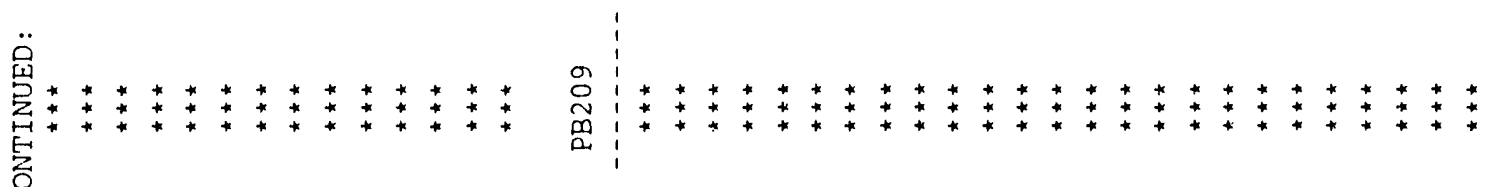

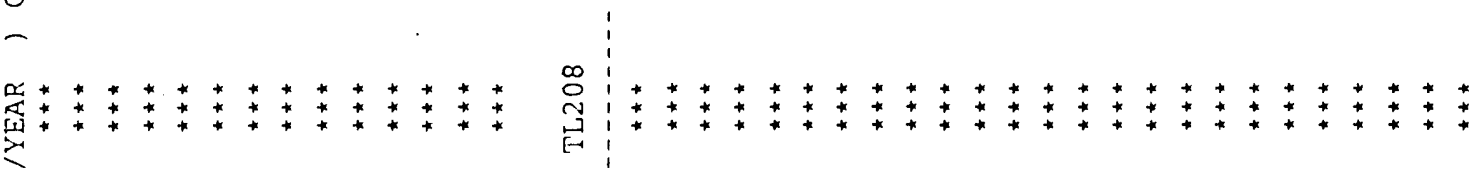
i

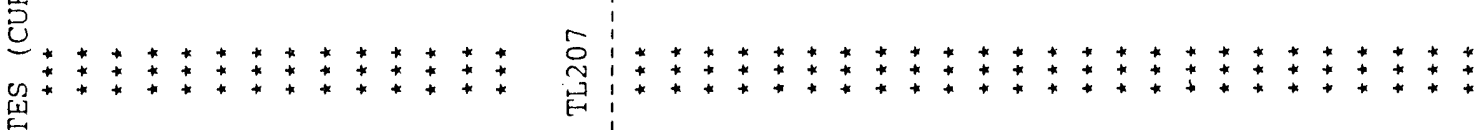
1

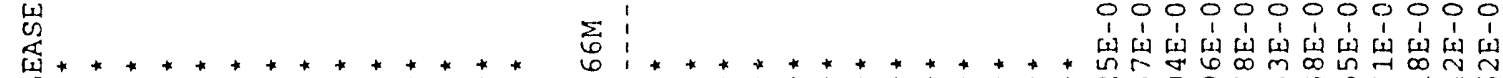

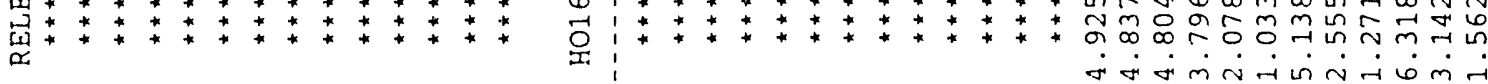
要

垈:

널 
$\varphi$

0
0
0

$\stackrel{\widetilde{N}}{\ddot{n}}$

$\underset{n}{\ddot{n}}$

$\stackrel{\sim}{\sim}$

\&ิ

U $1 \begin{aligned} & 1 \\ & \text { W }\end{aligned}$

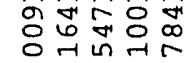

mंत्रें

ֻั

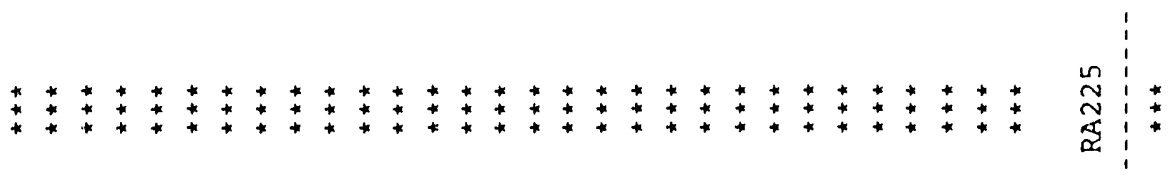

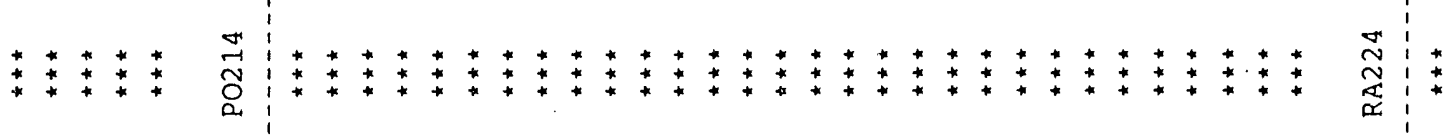

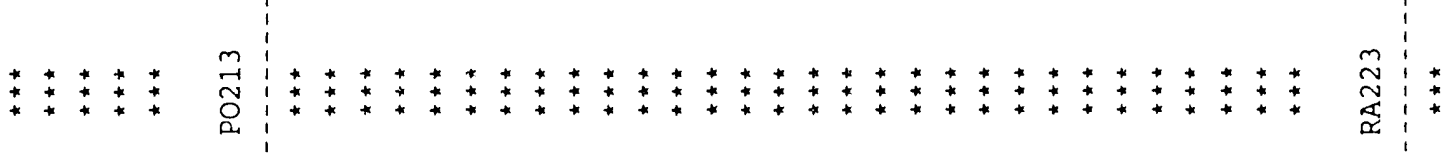

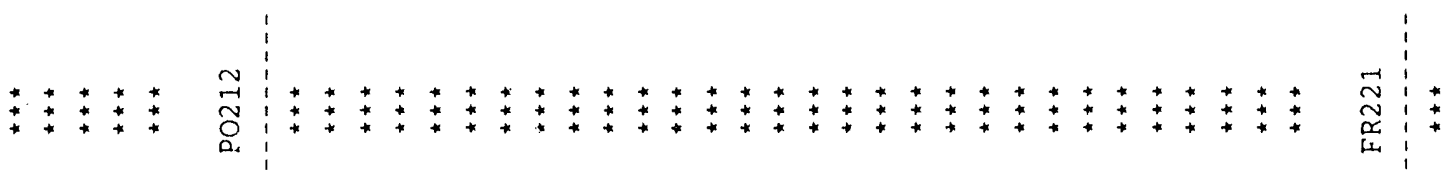

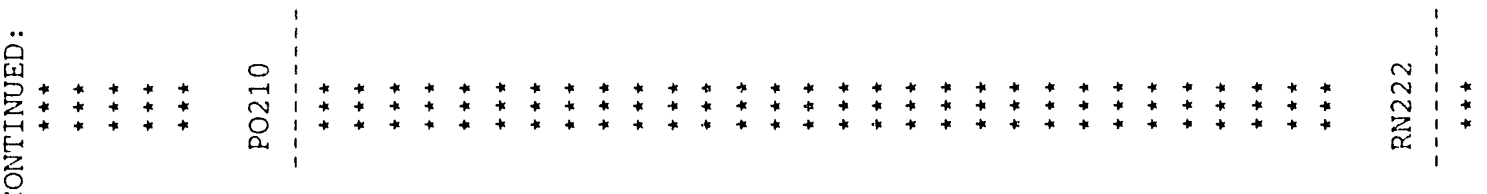
¿

$-$

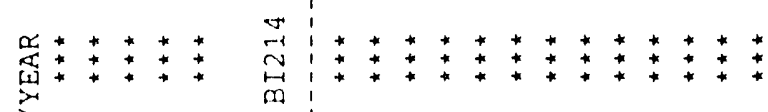

品

일

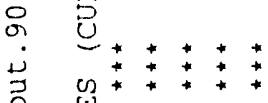

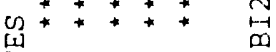

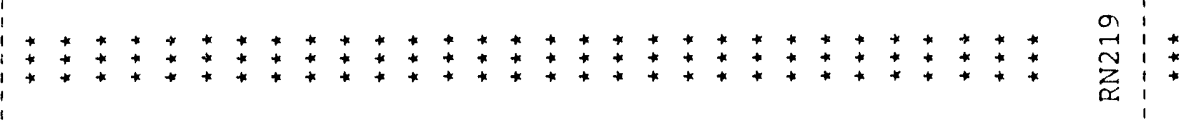

x

딴우웅

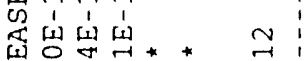

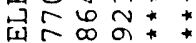

विं

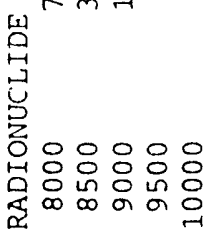

*

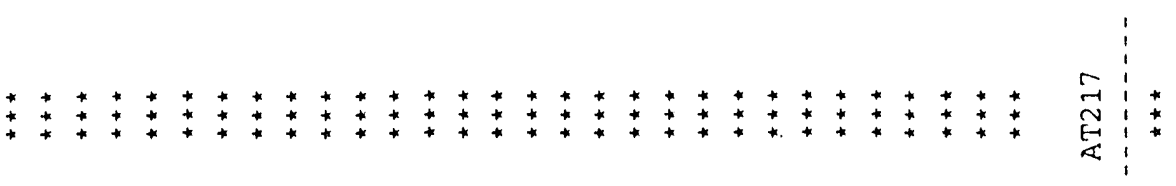

崖:

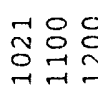

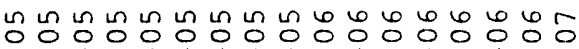

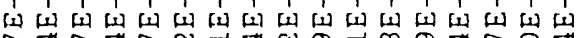

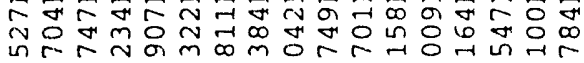

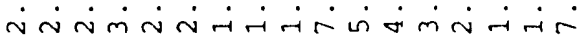

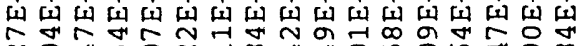

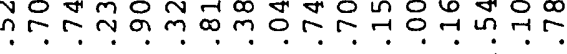

\begin{tabular}{l:l:} 
& $*$ \\
\hdashline & $*$
\end{tabular}

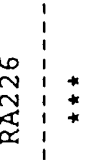

$\vdots$
$\vdots$
$\vdots$
$\vdots$
$\vdots$
$\vdots$
$*$

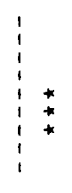

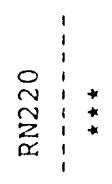

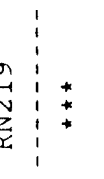

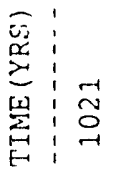

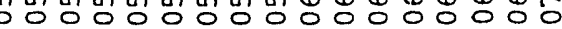




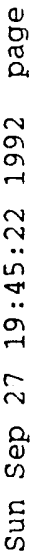

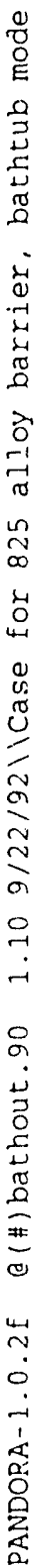

今

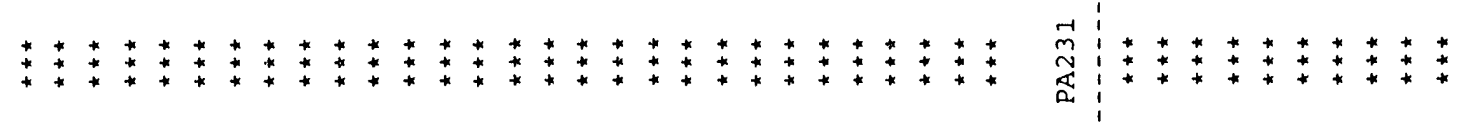

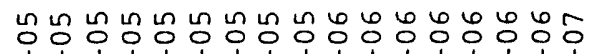

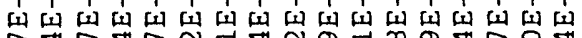

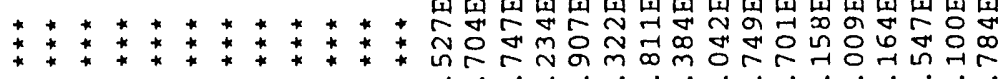

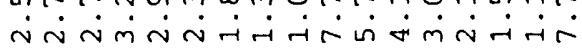

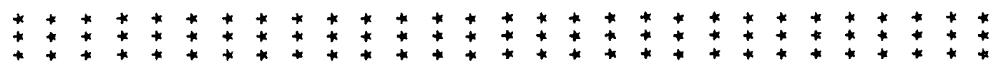

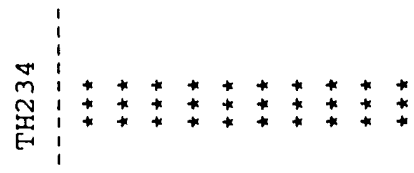

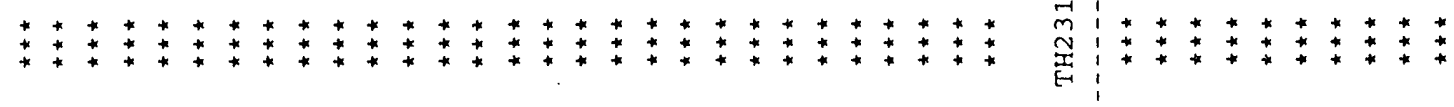

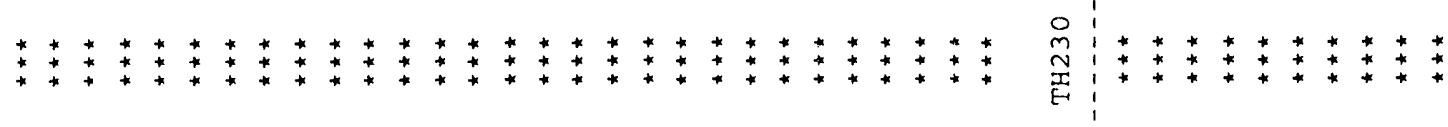

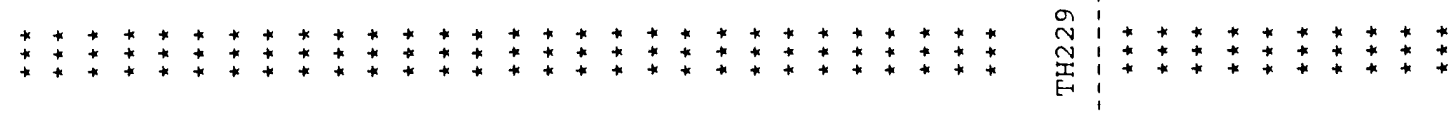

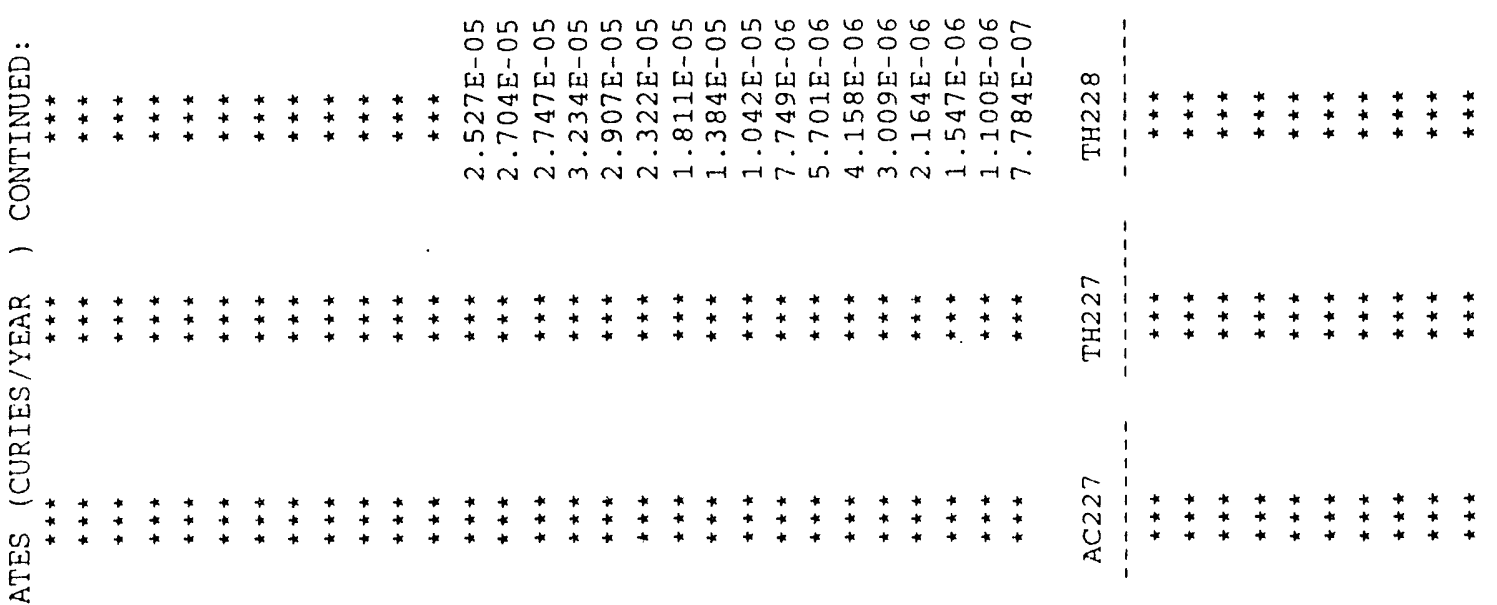
恶 稆

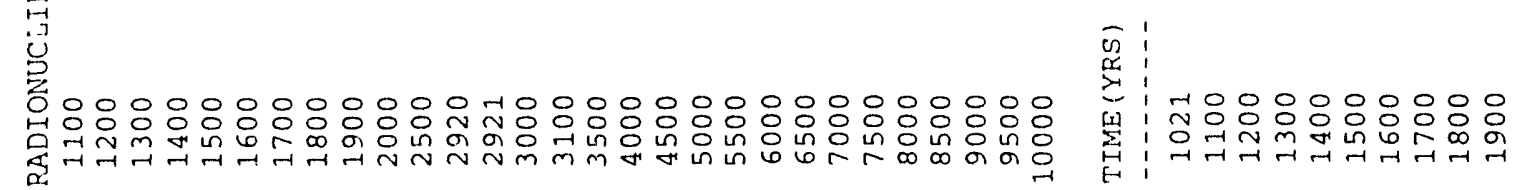




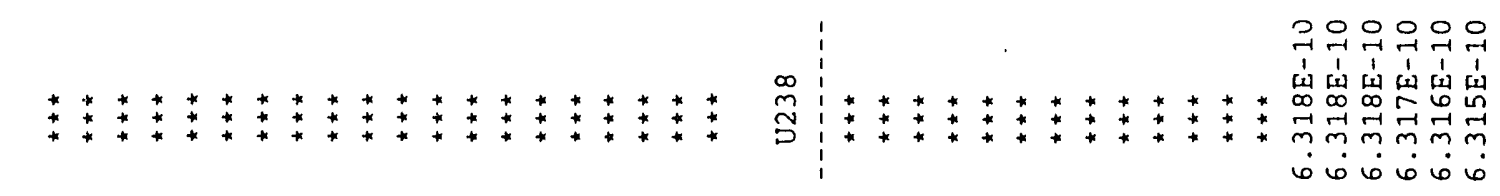

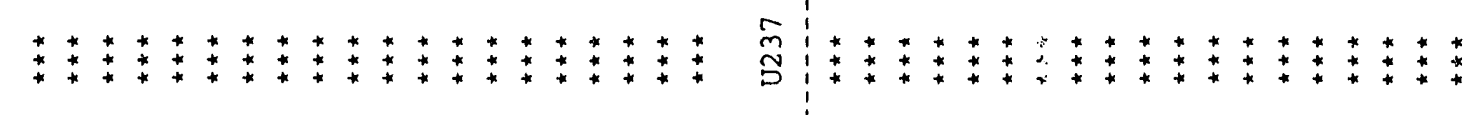
$\hat{\sim}$ $\stackrel{8}{\mathscr{8}}$

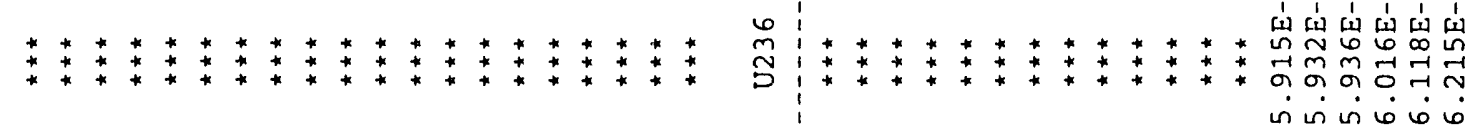

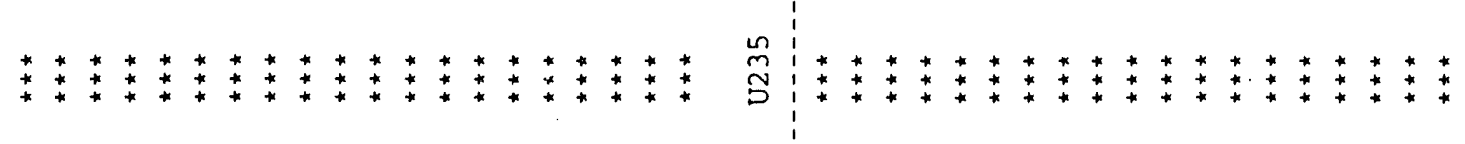

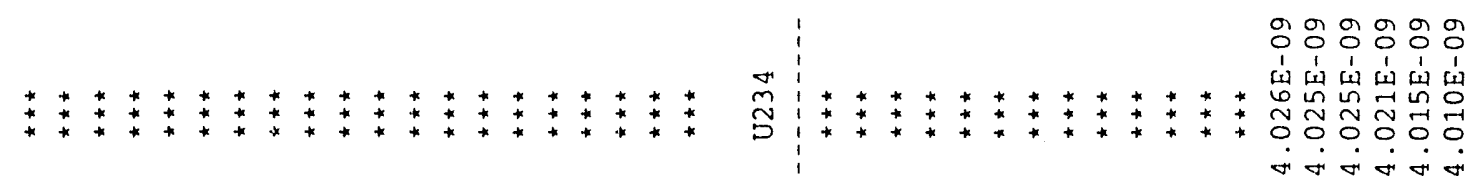

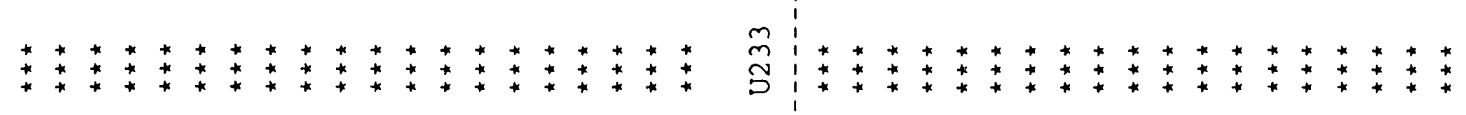

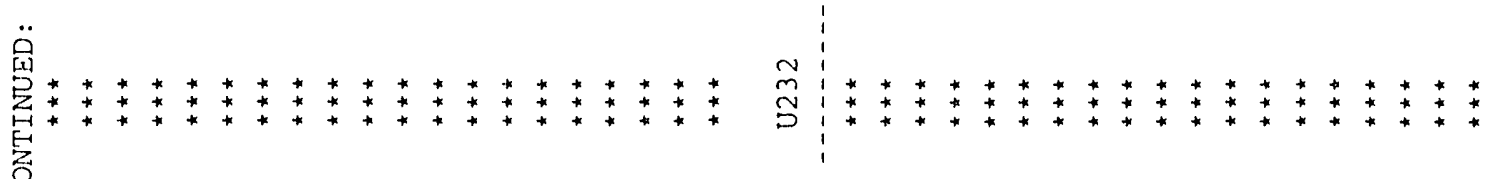

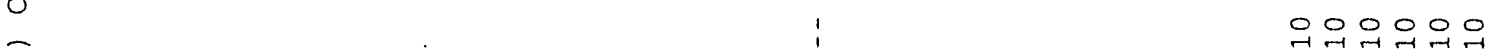

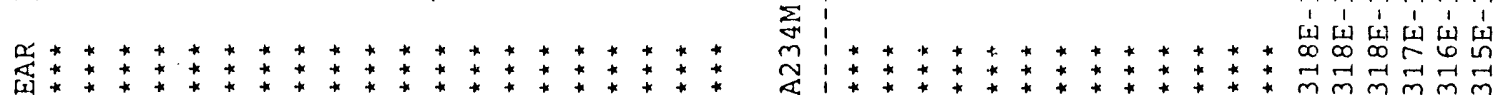

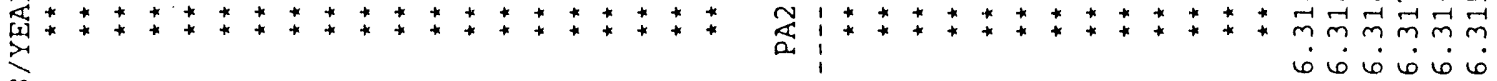
惫

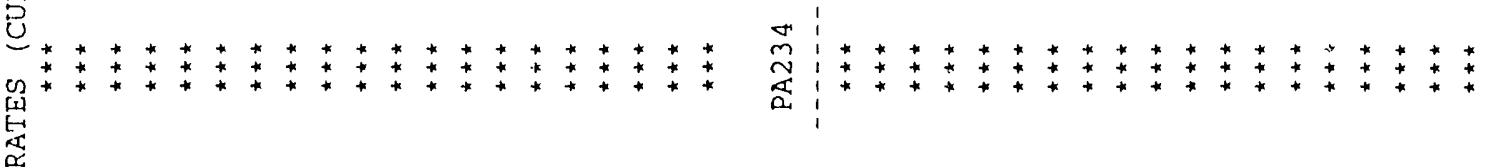

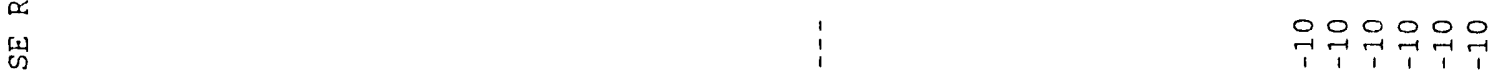

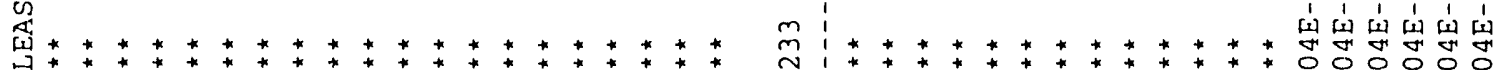

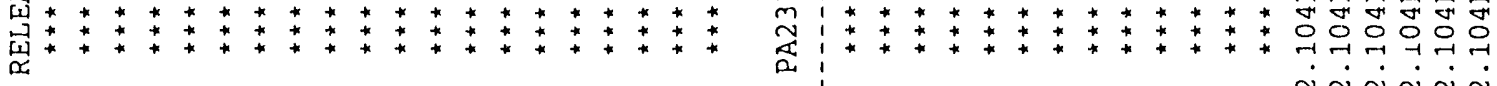
㟔

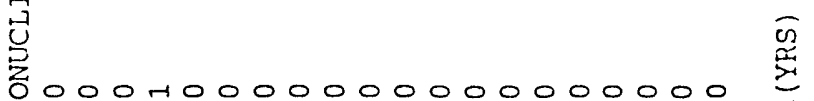

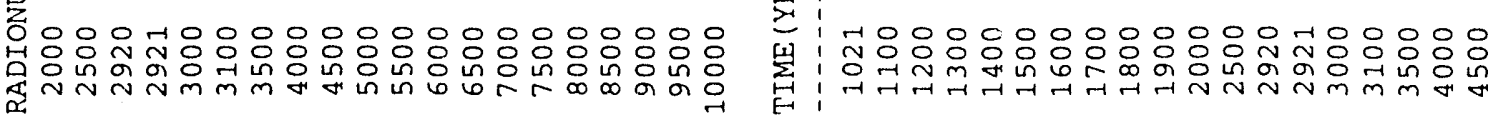


o

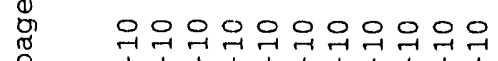

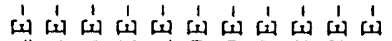
*m $m$ m

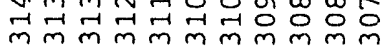
ن

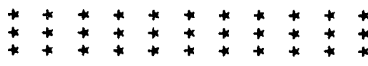

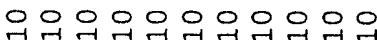

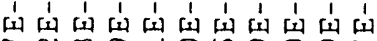

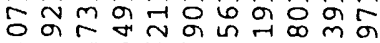

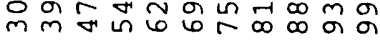
ن

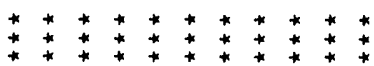

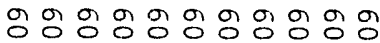

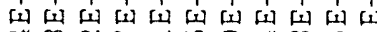

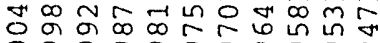

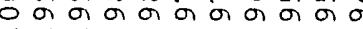
निंmm mंmmm

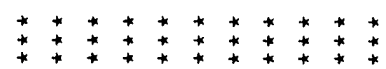

忩

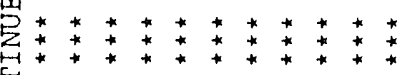
芩

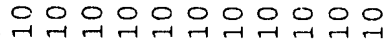

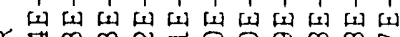

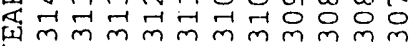

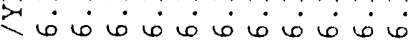

号

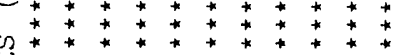
焉

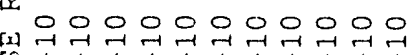

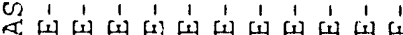

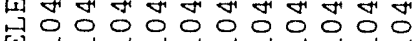

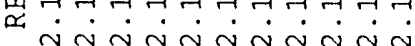
的

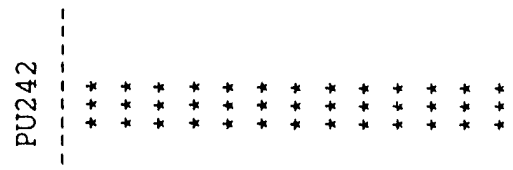

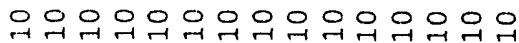

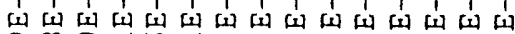

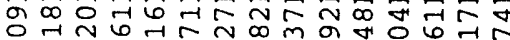

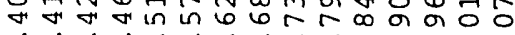
$\dot{\sim} \dot{\sim} \dot{\sim} \dot{\sim} \dot{\sim} \dot{\sim} \dot{\sim} \dot{\sim} \dot{\sim} \dot{m} \dot{m}$
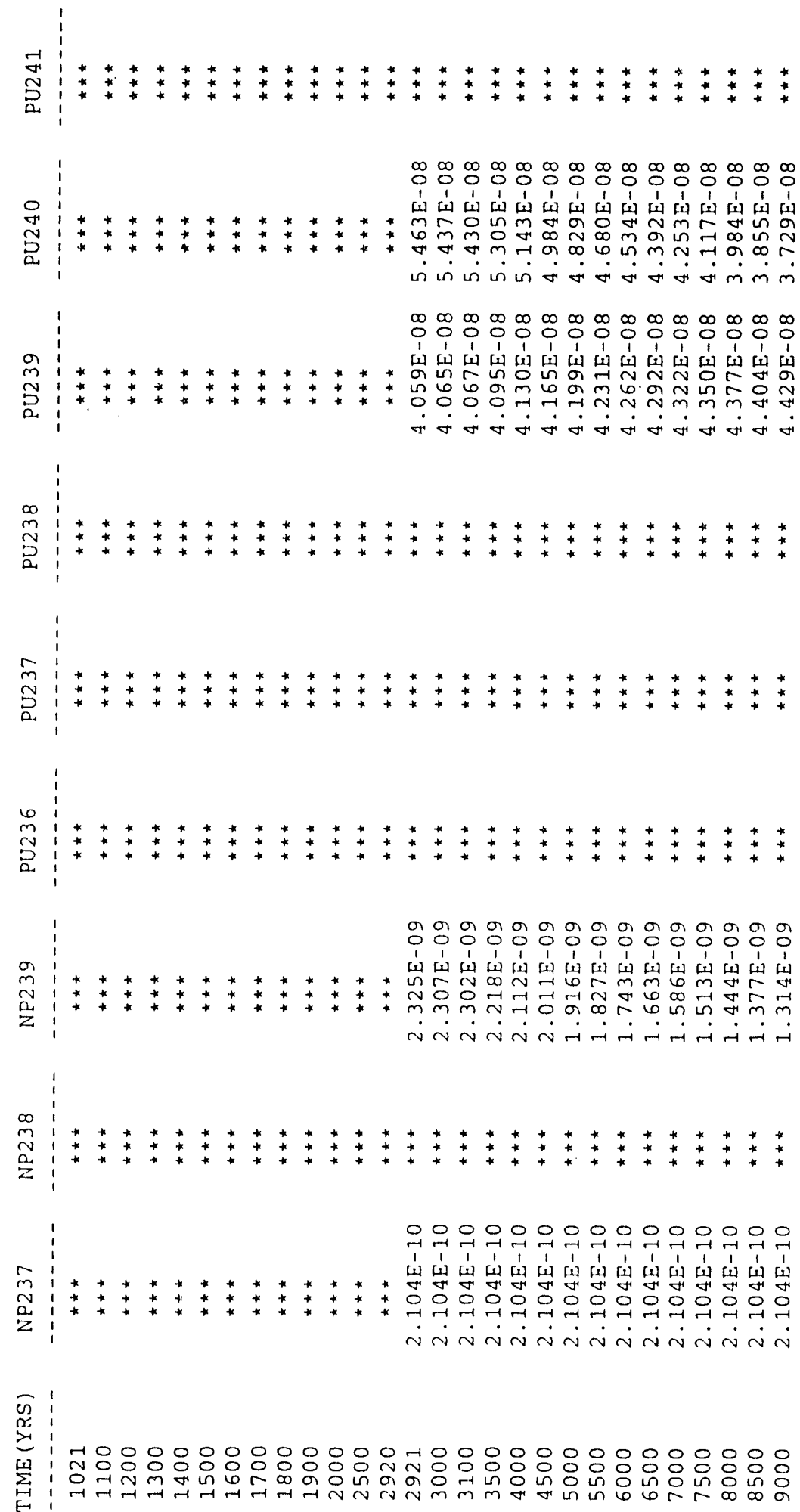


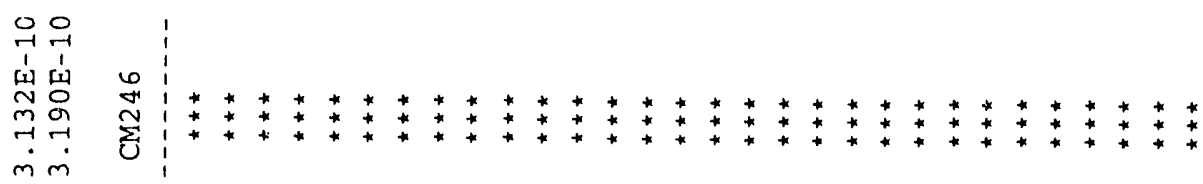

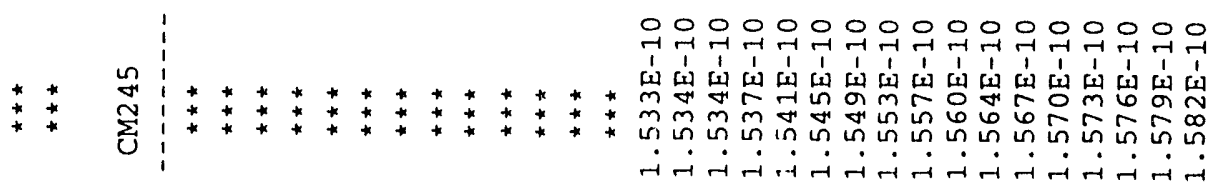
$\stackrel{\infty}{\infty}$

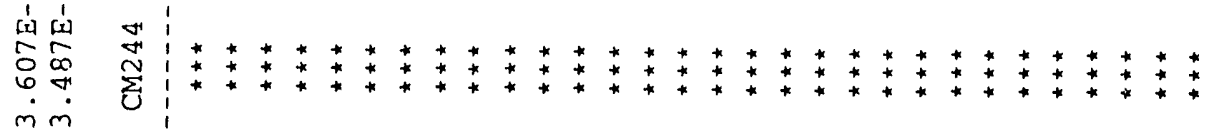

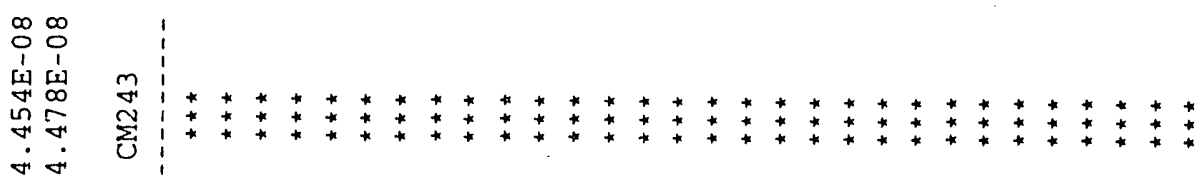
*

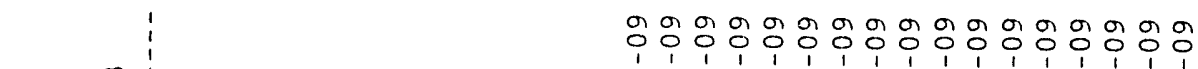

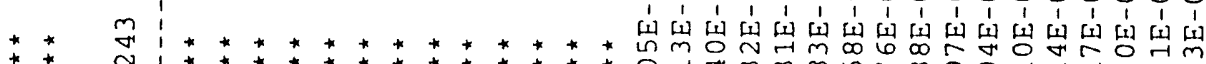

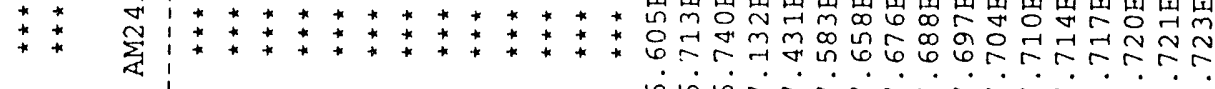
$\stackrel{\infty}{\sim}$

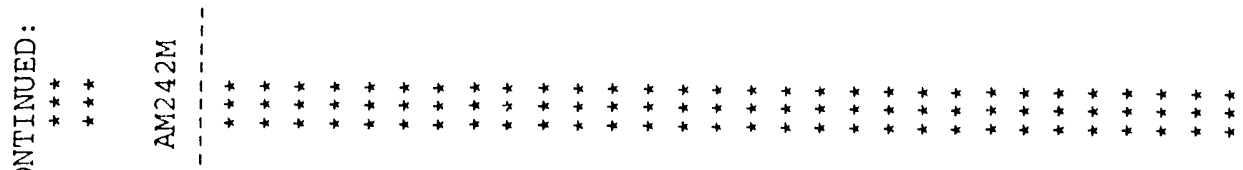
O - 잉용 出岕 $\approx$ $\sum_{i}$

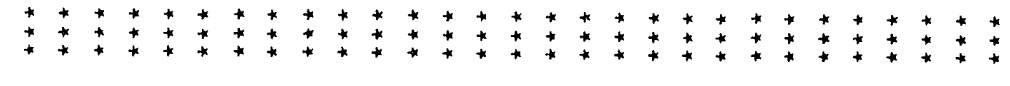
:

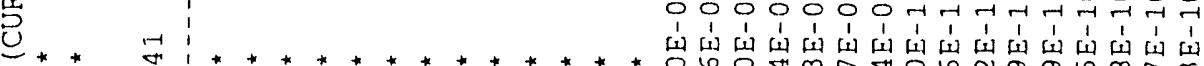

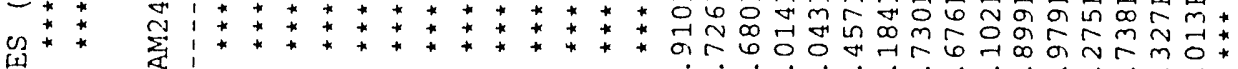
政

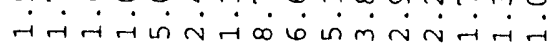

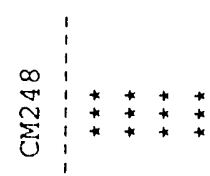

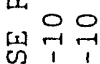

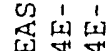
빘우을 N

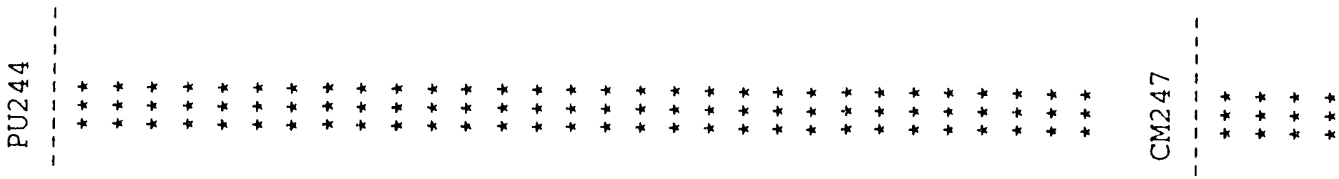




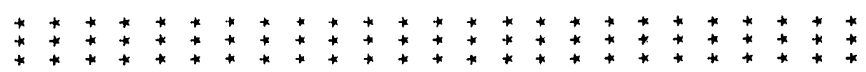


mor 11 1 1

ตั

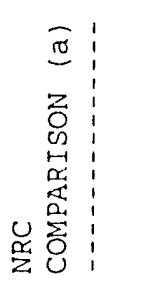

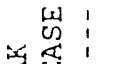

고그우

4⿴囗十

กิำ

$\dot{\sim} \dot{\sim} \dot{0}$

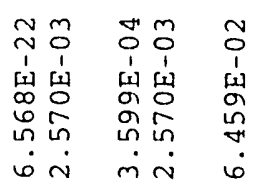




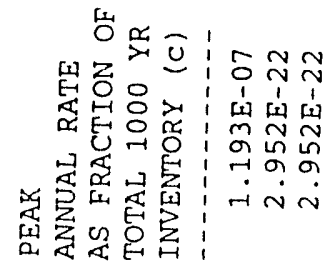

声

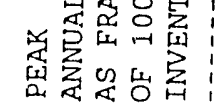
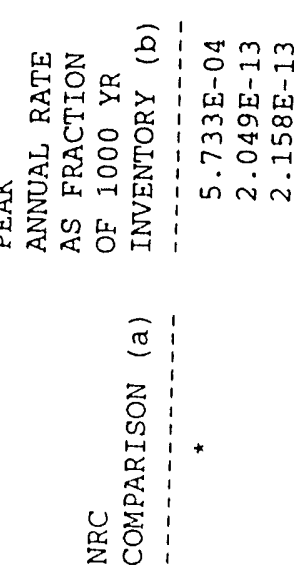

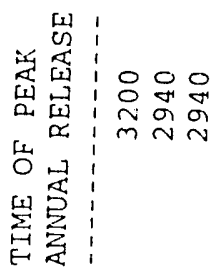

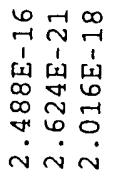

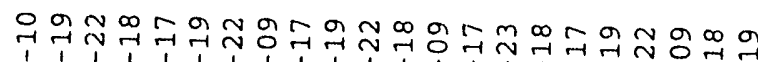

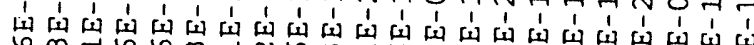

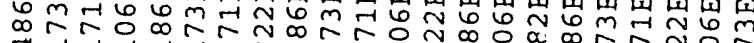

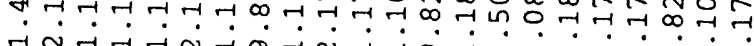

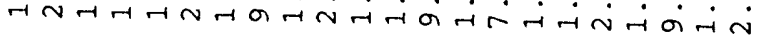

\section{冓需 \\ 때 \\ $-1+\infty, \frac{1}{\infty}$ \\ $0.0 \%$ \\ $\infty \dot{\infty} \dot{m}$}

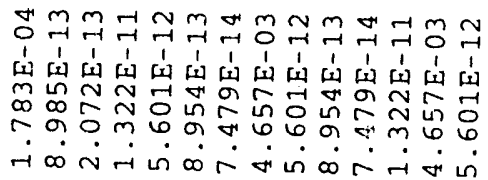

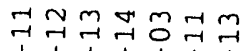

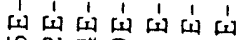

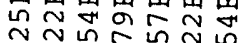

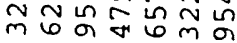
नi in

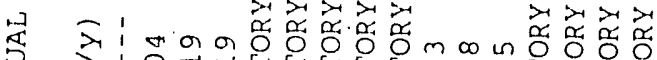

年 द्य

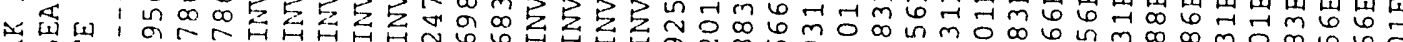
《.

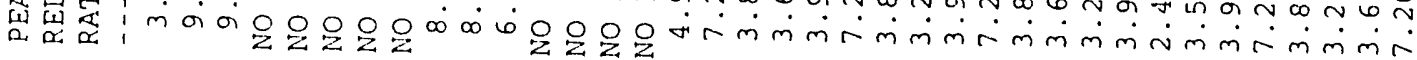

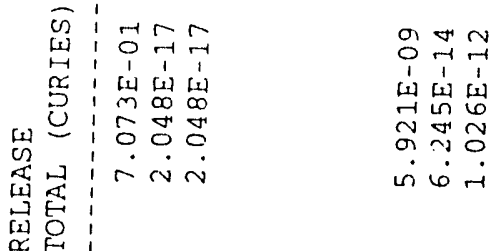

哇

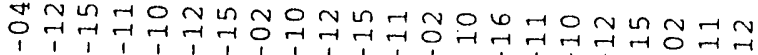

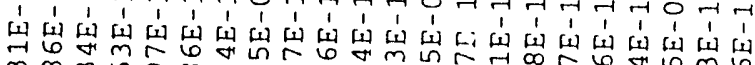
mºm

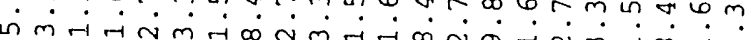




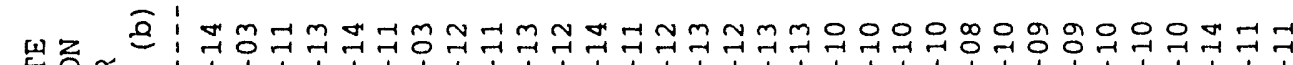

س

风它。范

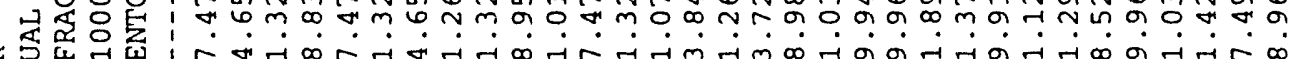

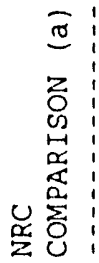

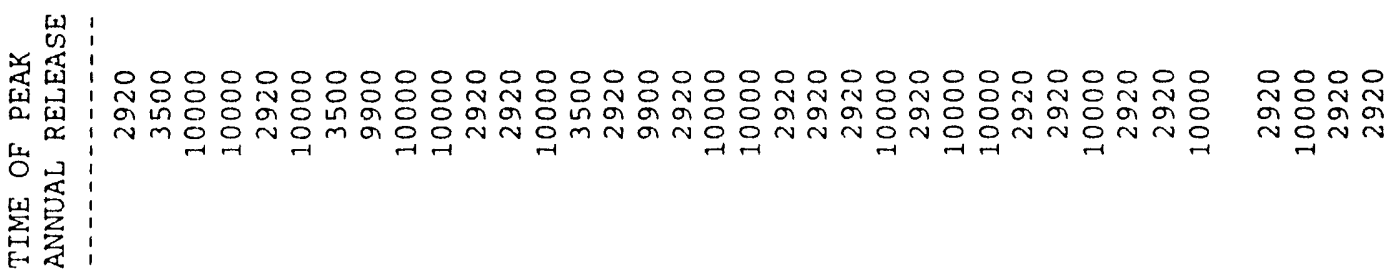

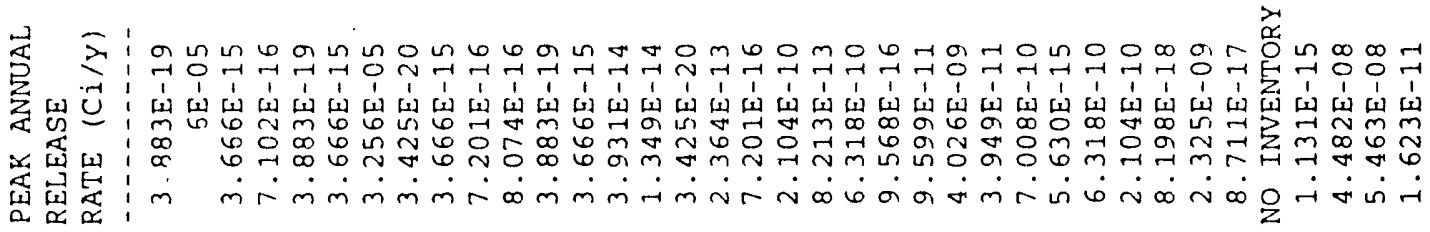

ब년

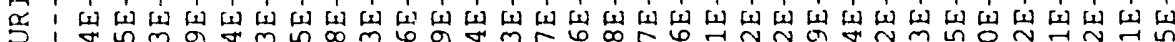
w U. ש

궁ㅎㅇ응

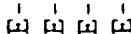
m क 嶳 可是!

$\dot{m} \dot{m} \dot{x}-$

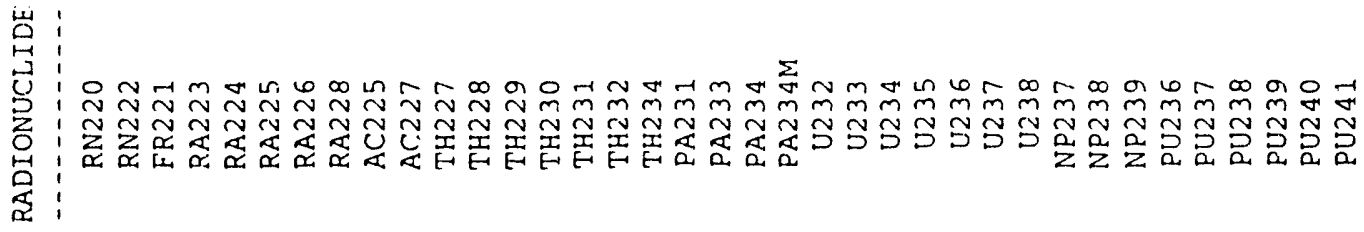




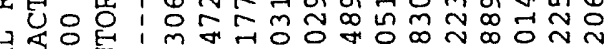

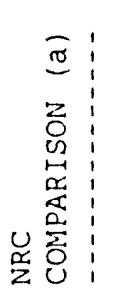

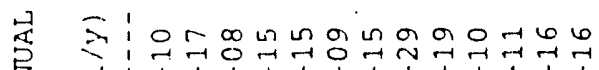

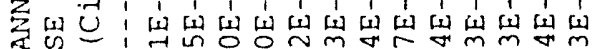

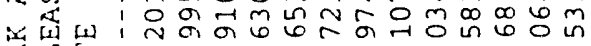

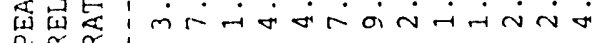

武

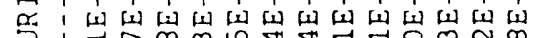

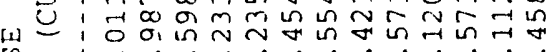
की

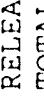




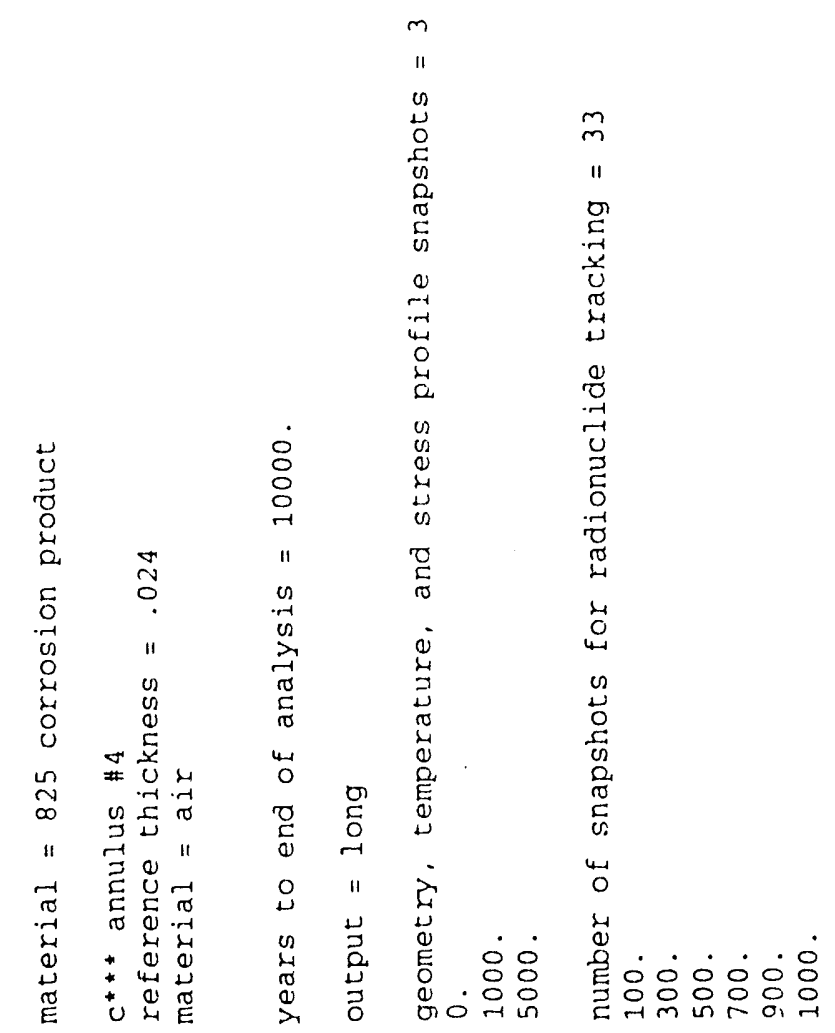




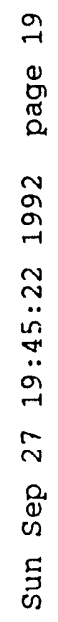

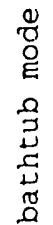

范

굼

$\stackrel{\sim}{\infty}$

号

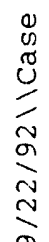

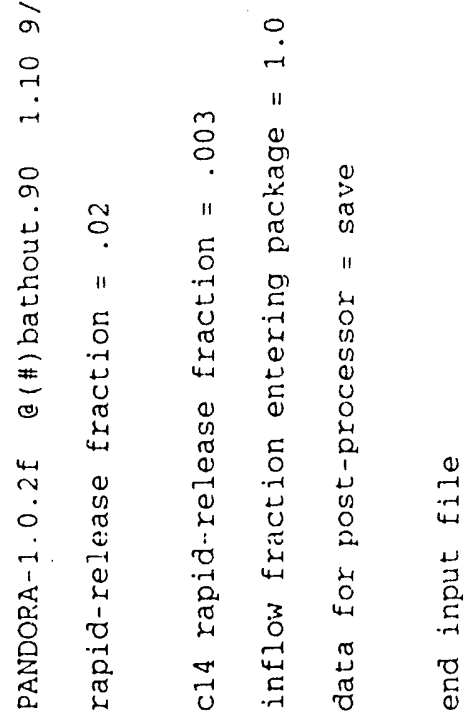


FLOW-THRU MODE 


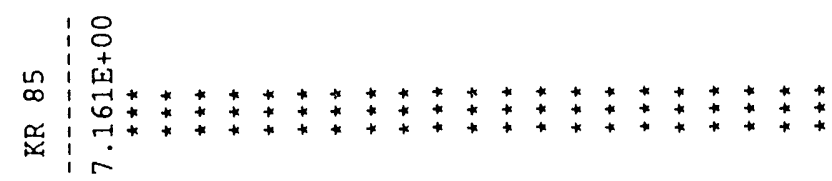

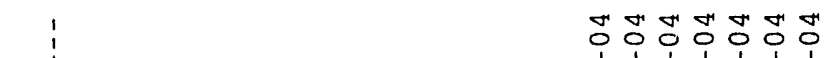

o

w
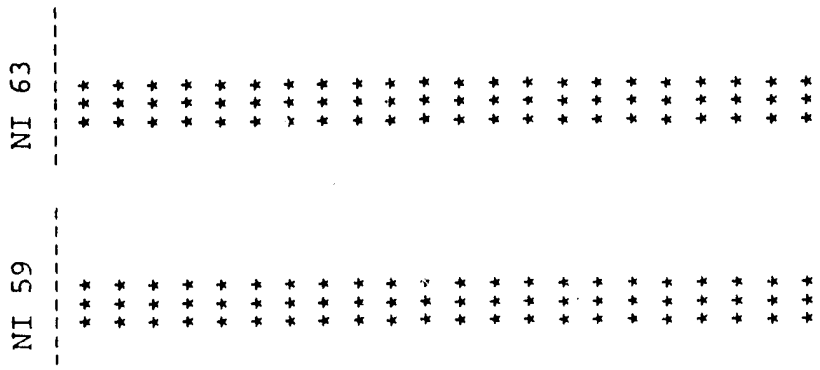

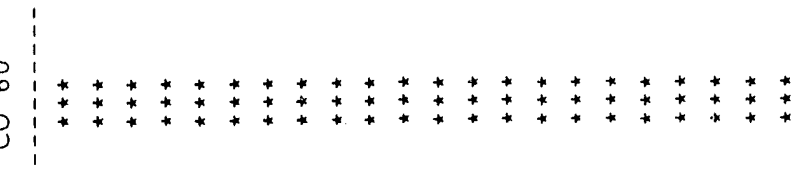

出峞

8

究
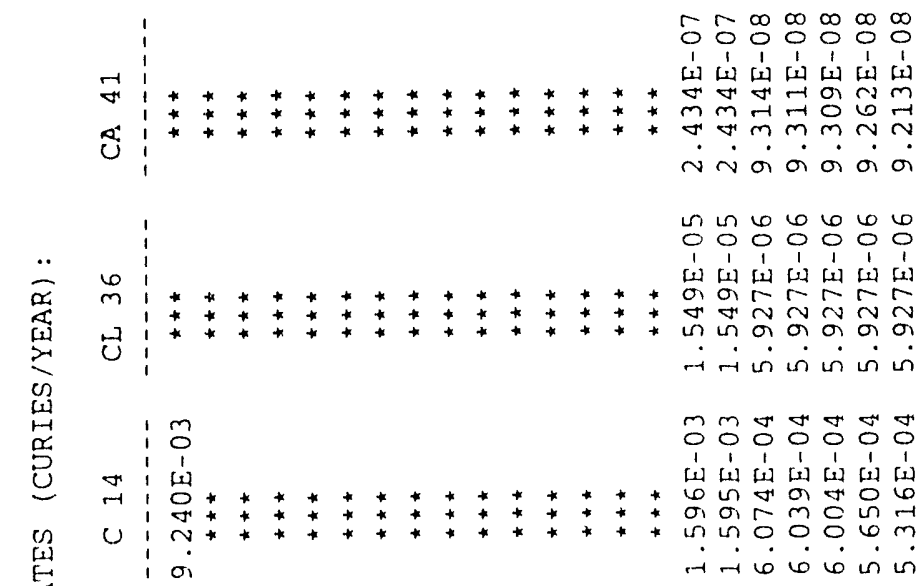

$\overline{0}:$ 
$N$

:

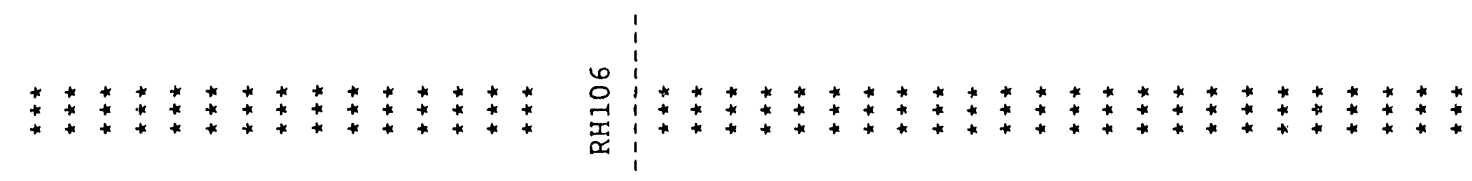

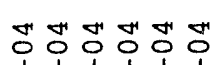

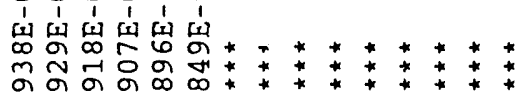

नंनंनंनं

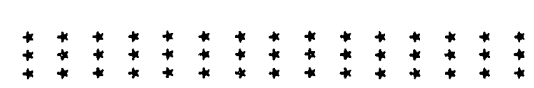

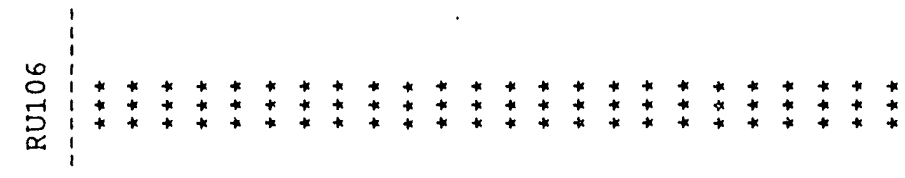

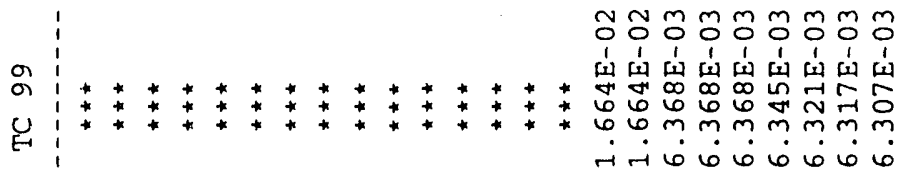<smiles>[Y]C(C)C</smiles>

on:

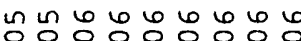

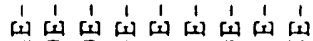

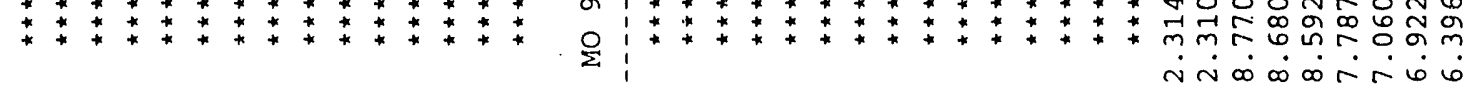

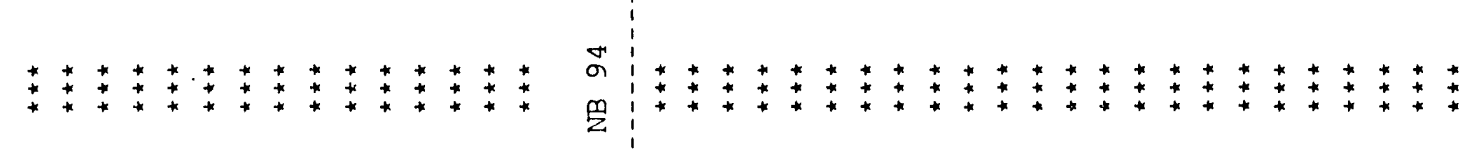

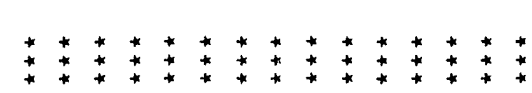

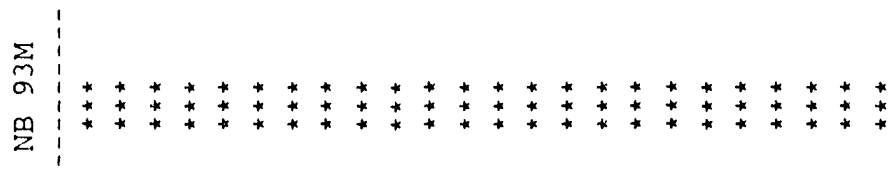

..

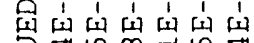

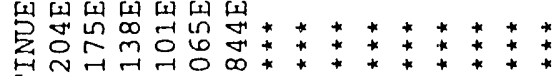
बं बं बं बं

- $0006060 \%$

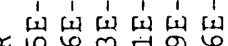

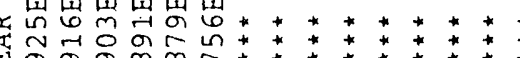

خ in in

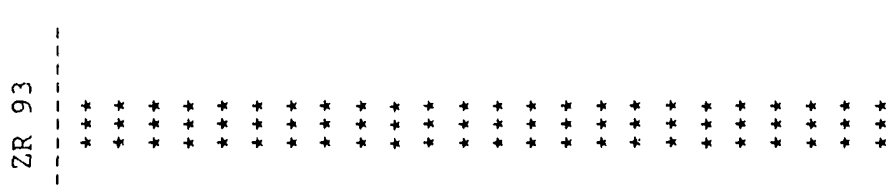

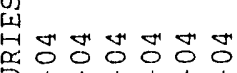

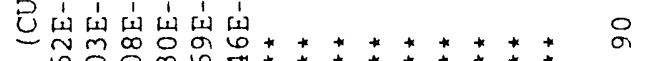

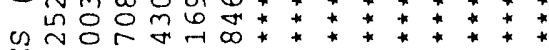

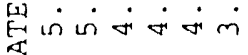

os

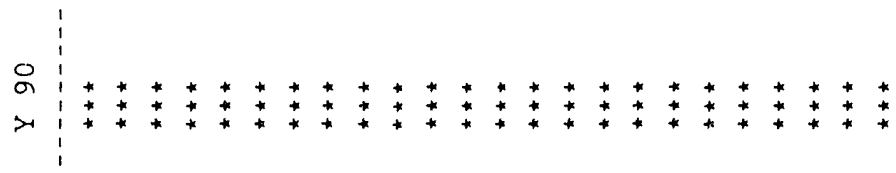
[1]

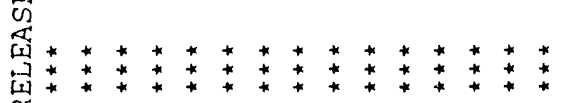

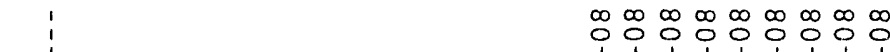

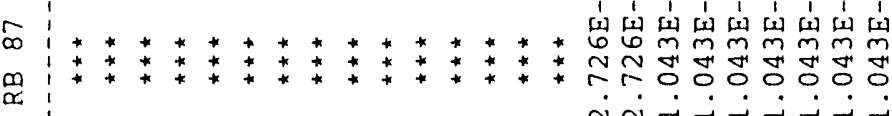
at $\stackrel{?}{\circ}$ 


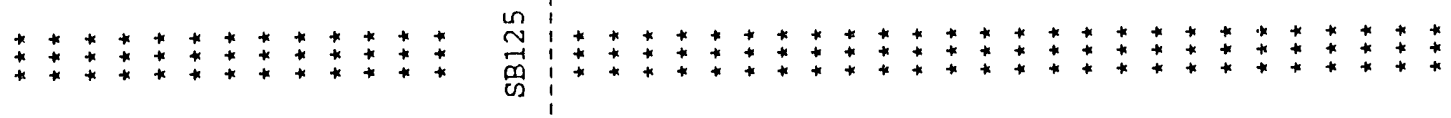

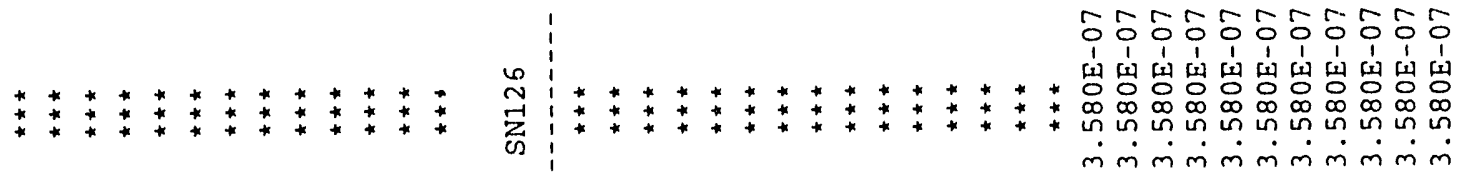

ํํㅇํํㅇํㅇ

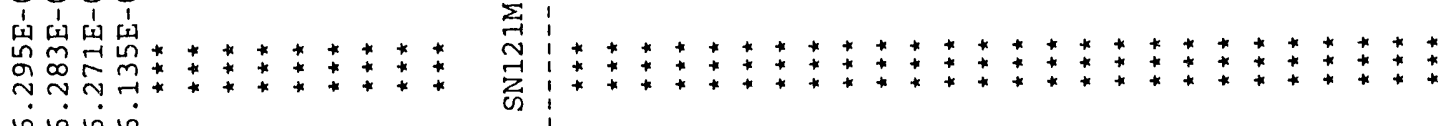
०ं 6

$\because 00 \%$

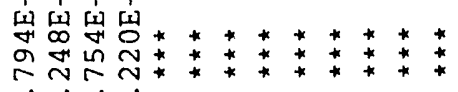

نं

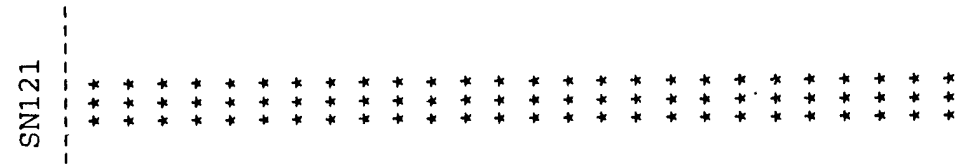

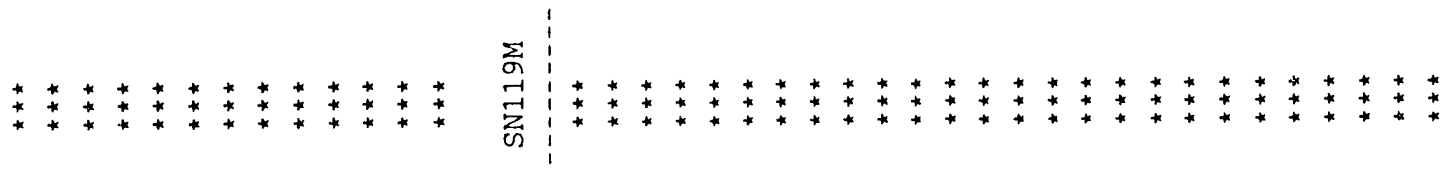

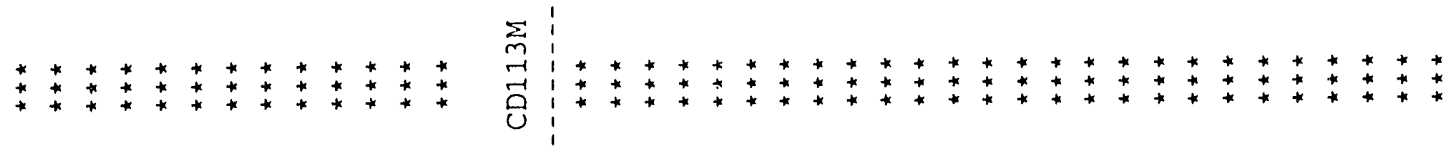

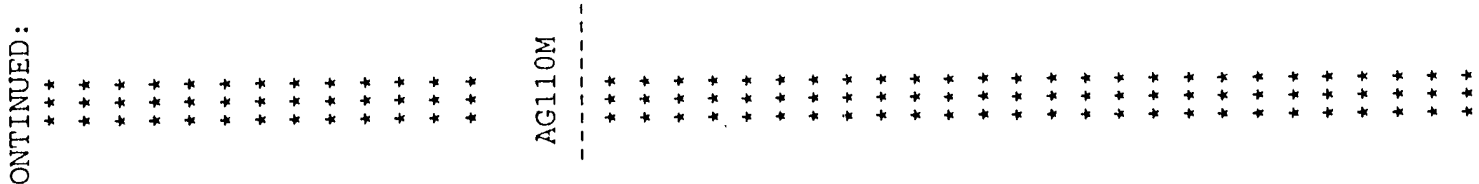

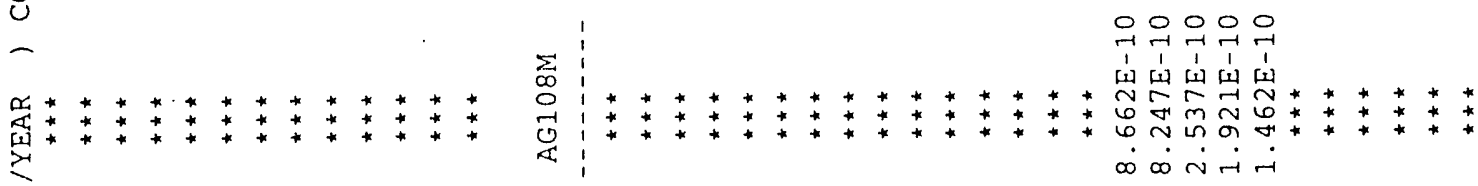
点 占

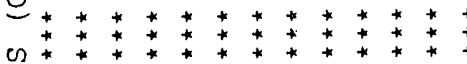
空

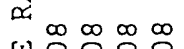

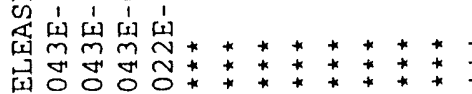

व

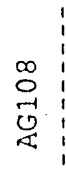

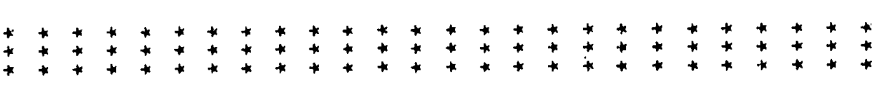

$\stackrel{4}{\sim}$

高

窎

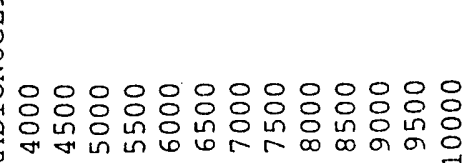

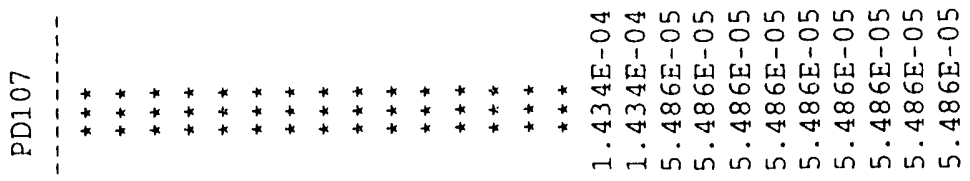

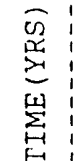

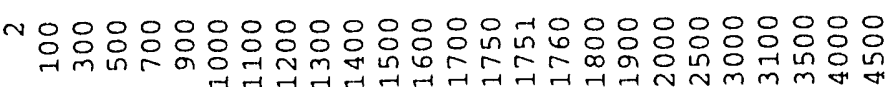




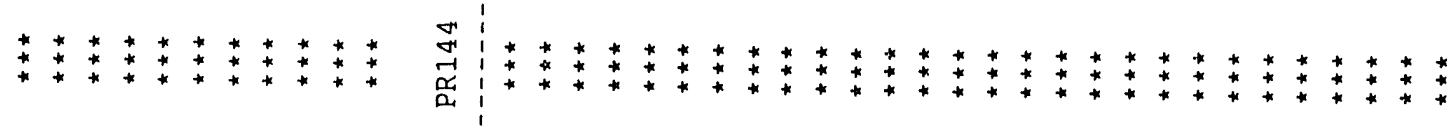

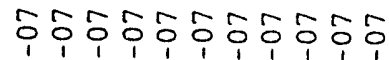

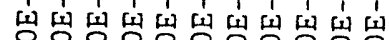

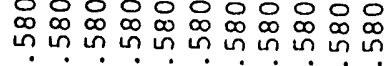

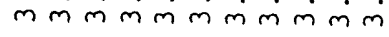

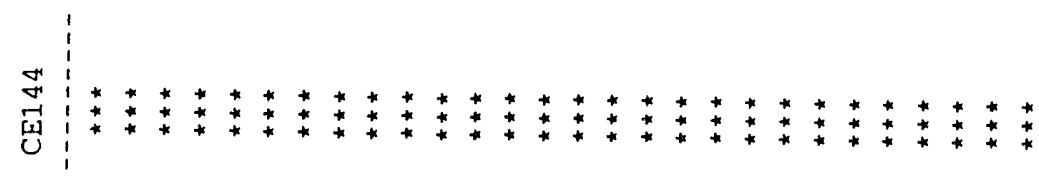

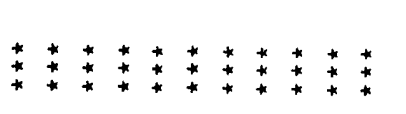
$\underset{⿱}{\sum}:$

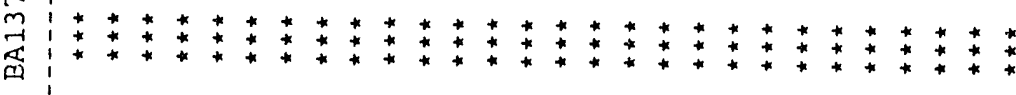

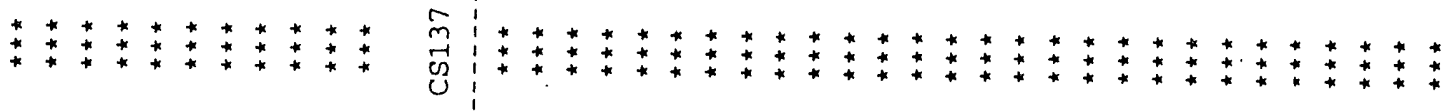
: : : : : : : : : : :

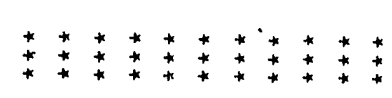
若

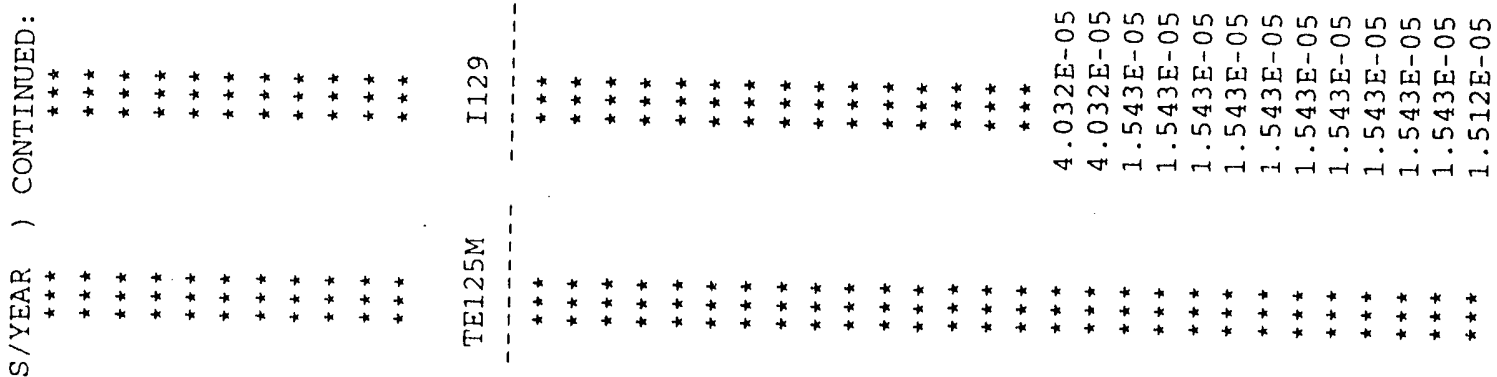
留

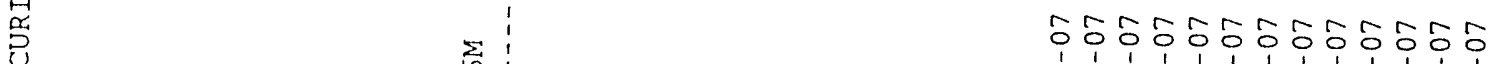

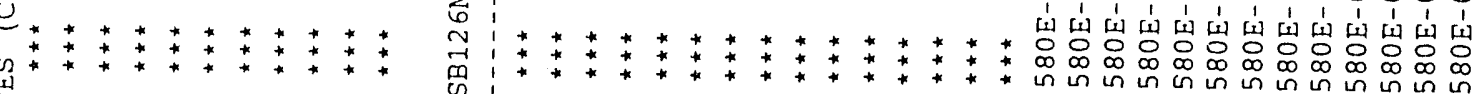
wit 蛋 때 $\ln$ in

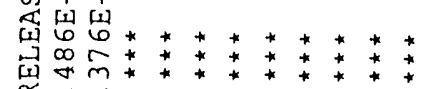
贾的 $\dot{m} \dot{m} \dot{m} \dot{m} \dot{m} \dot{m} \dot{m} \dot{m} \dot{m} \dot{m} \dot{m}$ ن

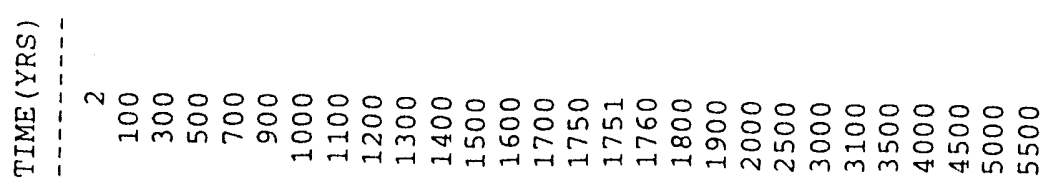


๑

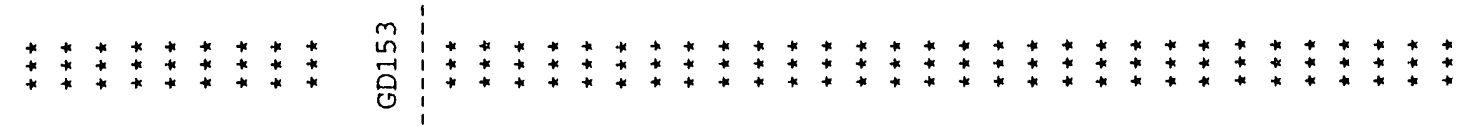

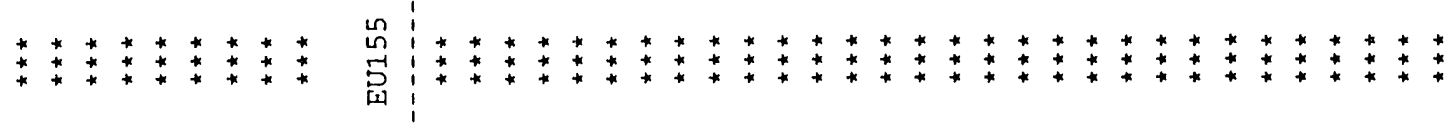

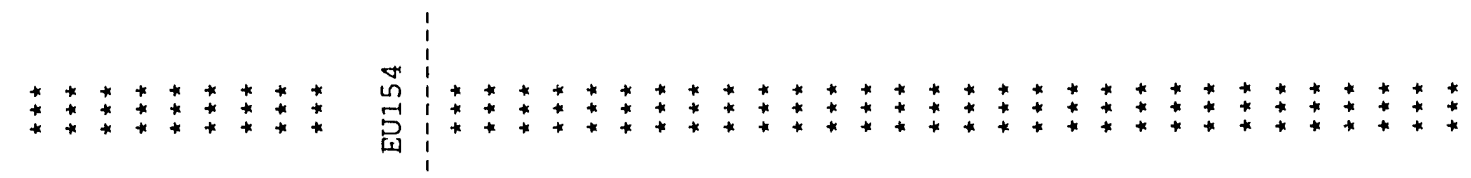

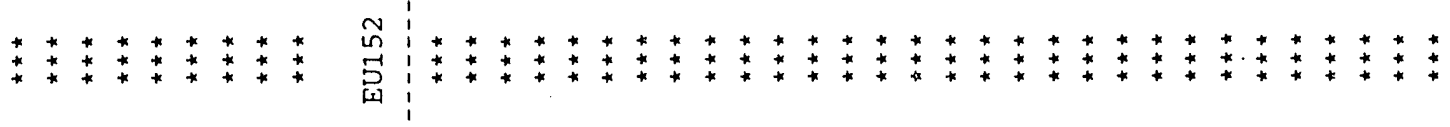

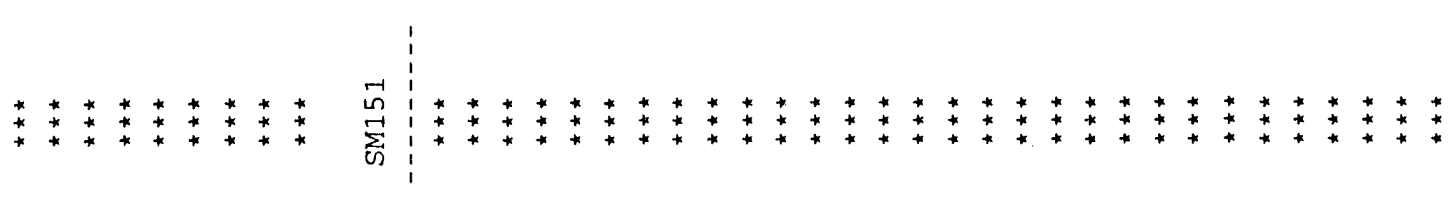

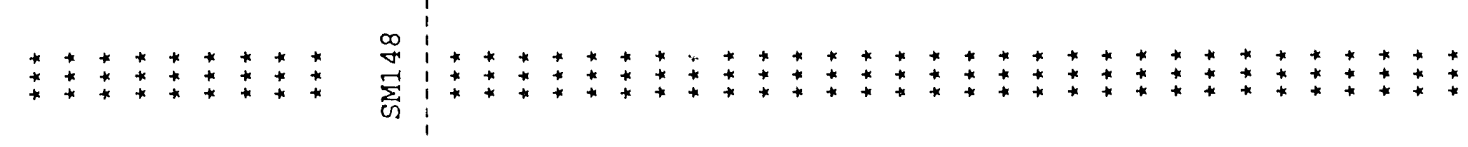
$\underbrace{0}_{0}$

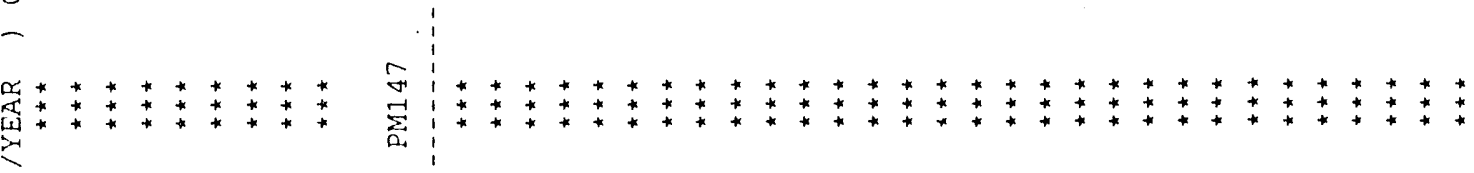

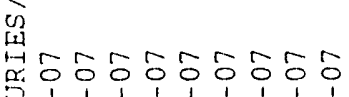

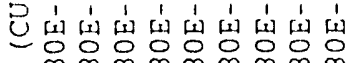

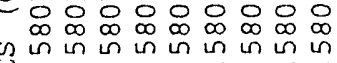
H.

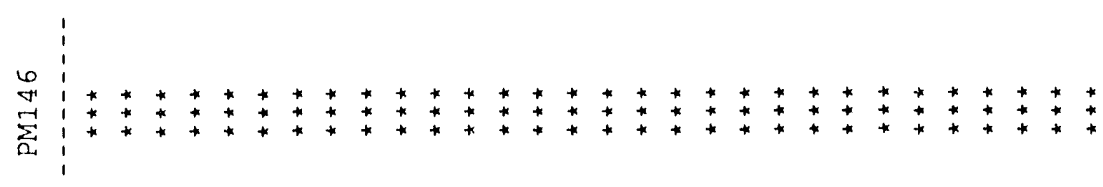

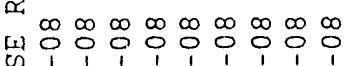

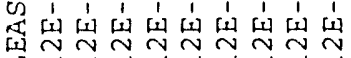

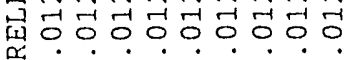

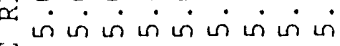
\begin{tabular}{l|l}
\hline \\
\hline
\end{tabular}

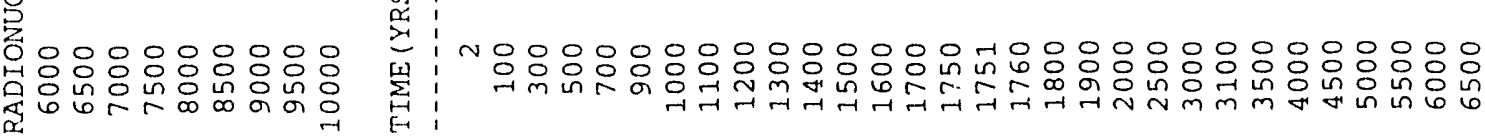


6

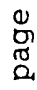

๙ั

$m$

$\ddot{\sigma}$

g

i

की

ต

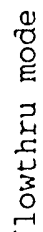

i

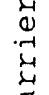

ते

in

$\infty$

峁

荍

$=8$

N

$\stackrel{N}{N}$

के

a)

용

วิ

尔

핑

出

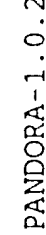

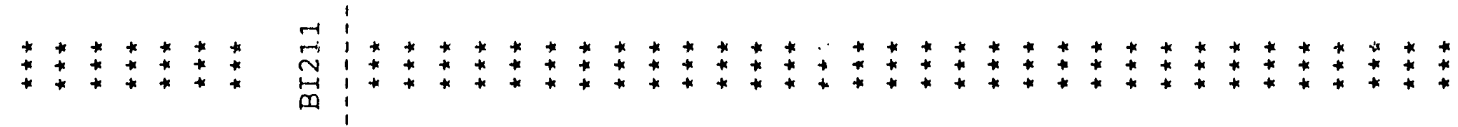

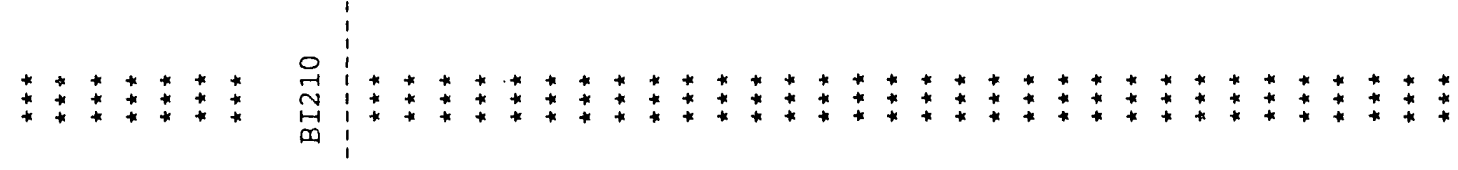

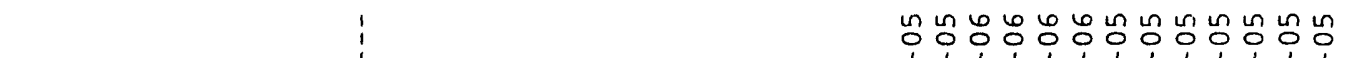

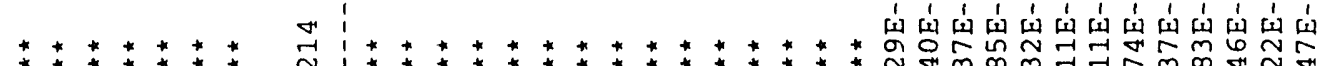

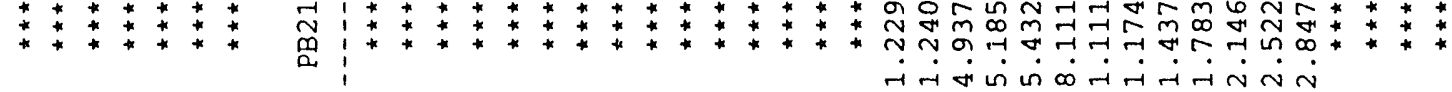

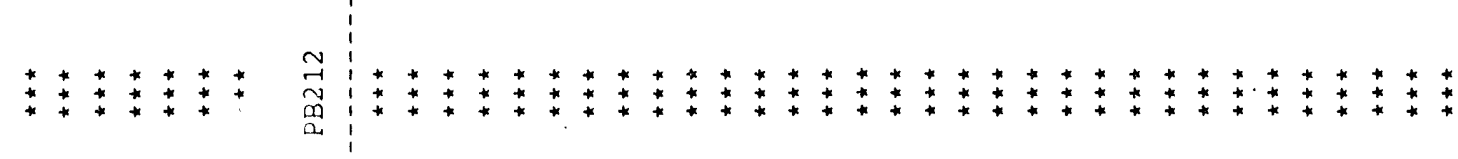
*

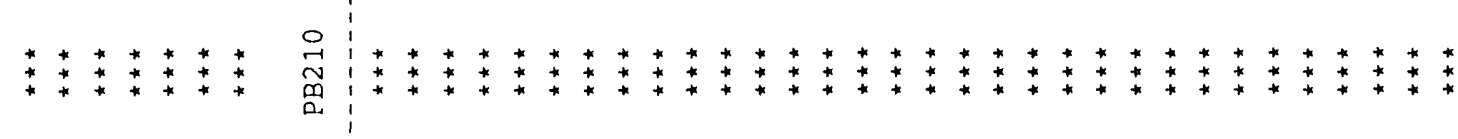

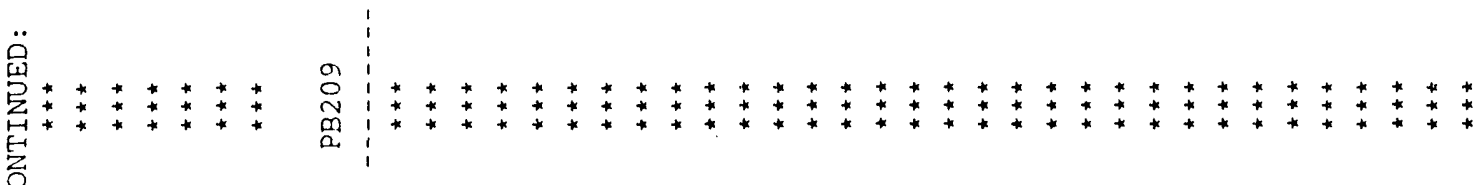

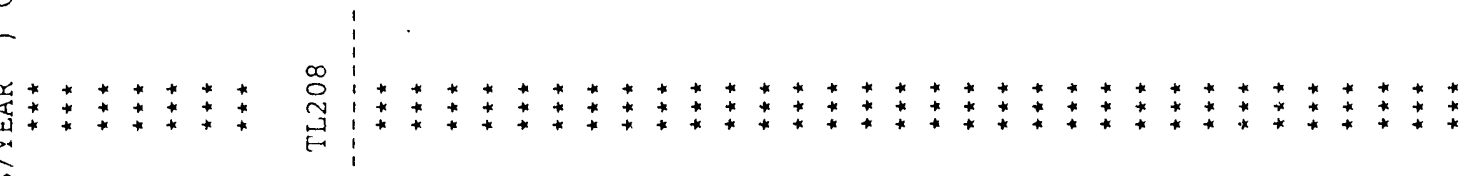
舀

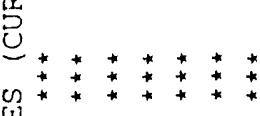

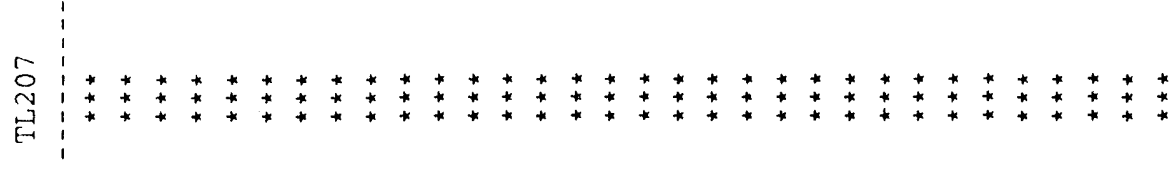

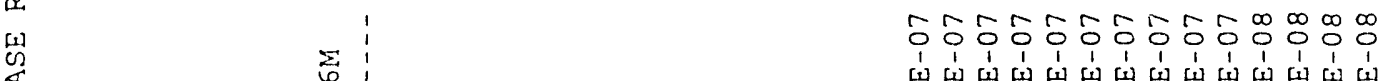

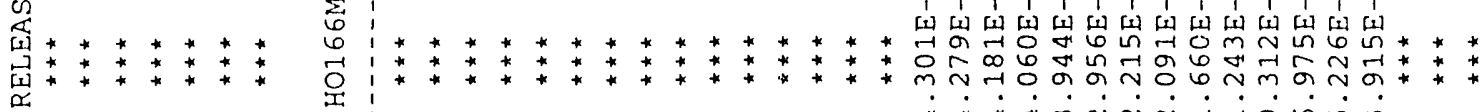
$\stackrel{[19}{⿶}$

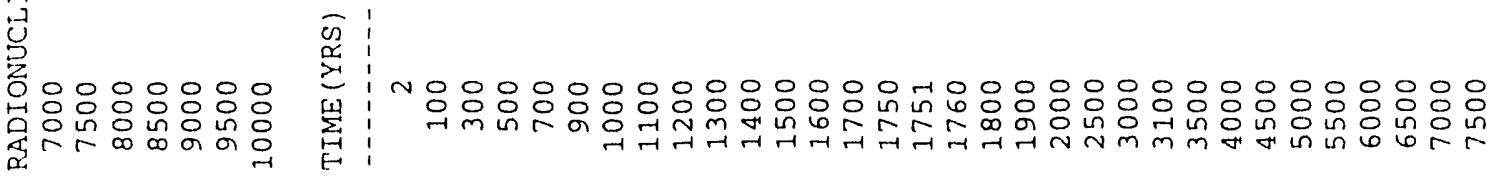




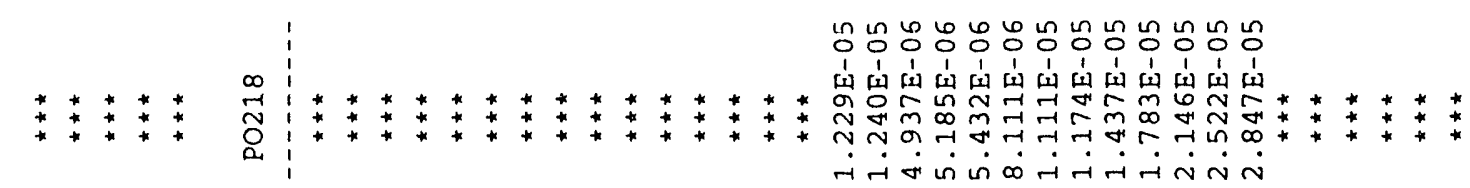

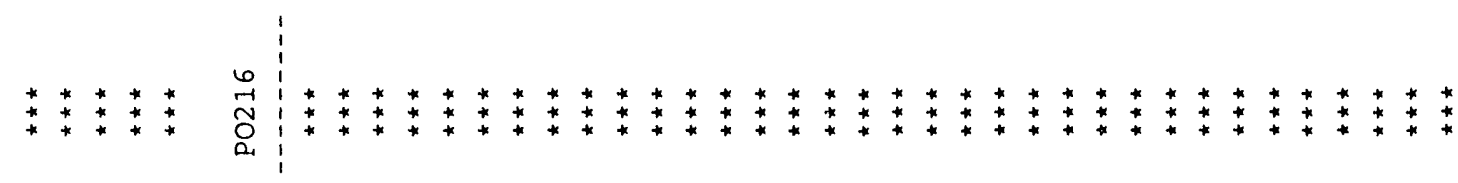

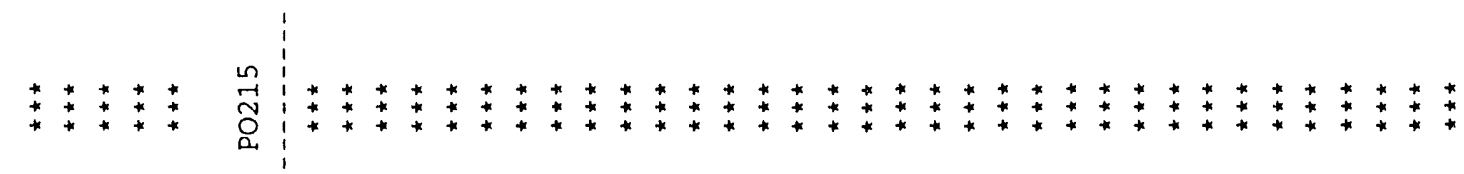
* *

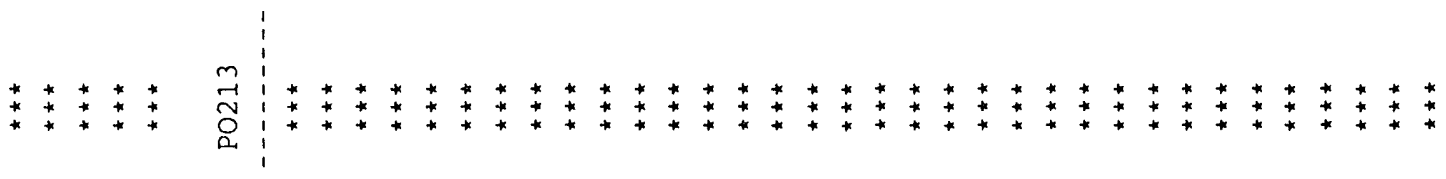
*

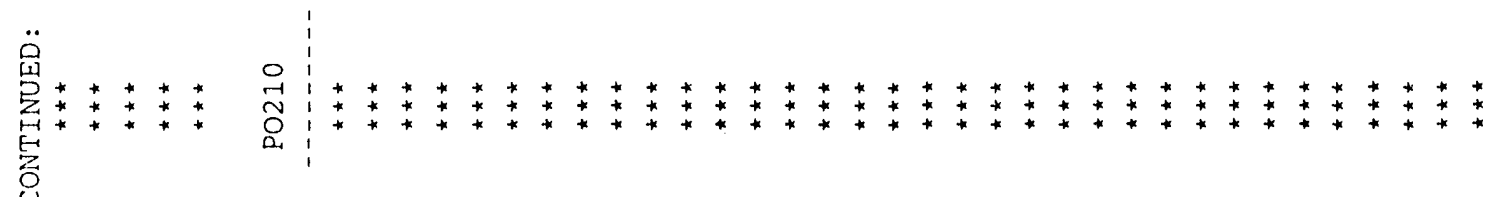
- . .

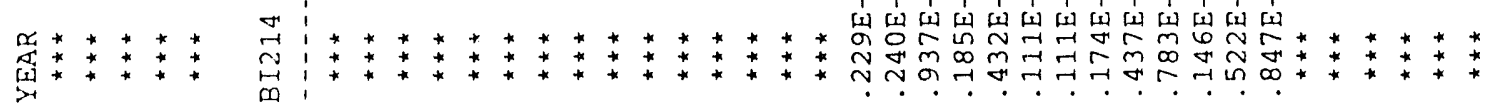
$\underbrace{*+* * *}$

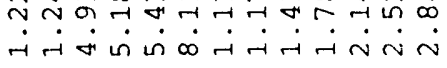

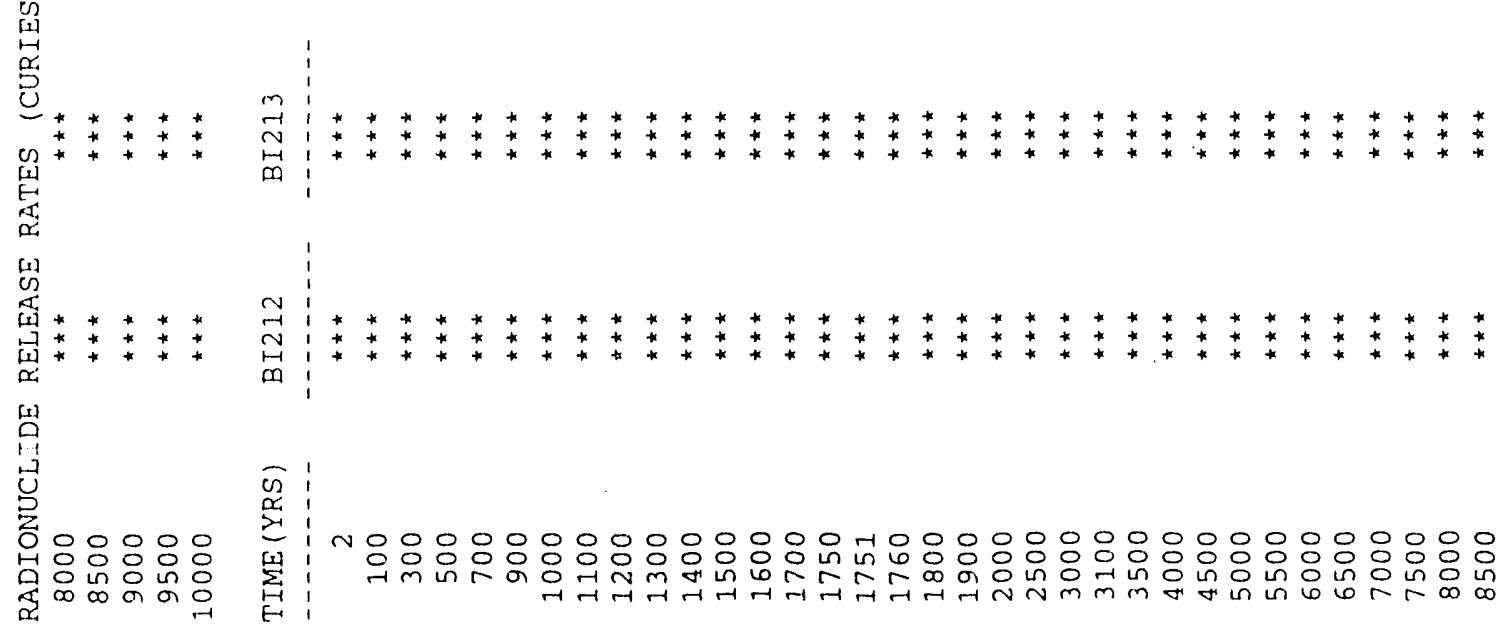




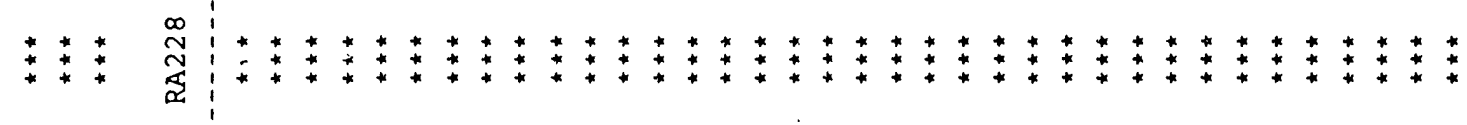

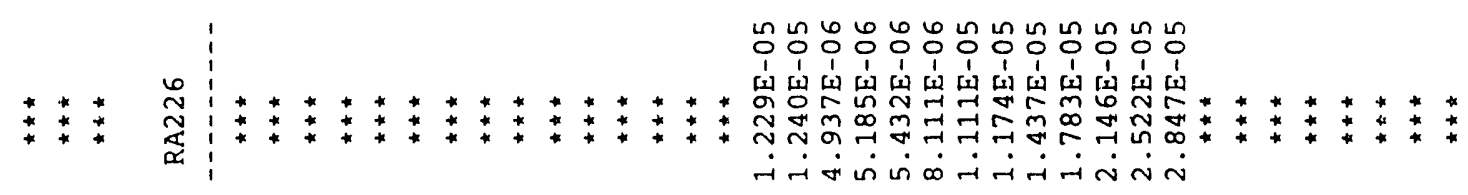
r.

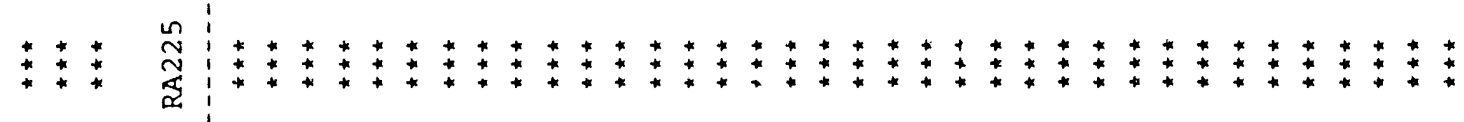

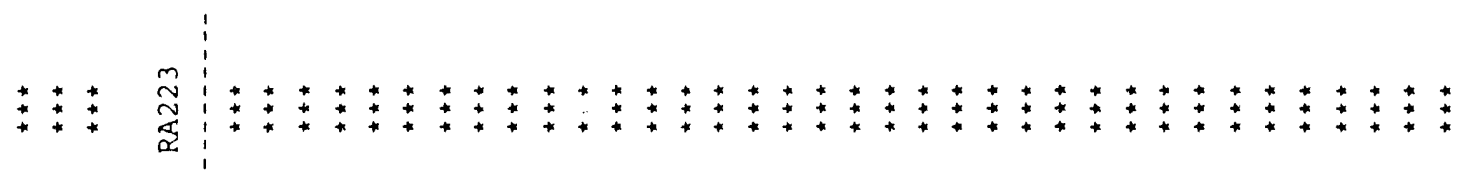

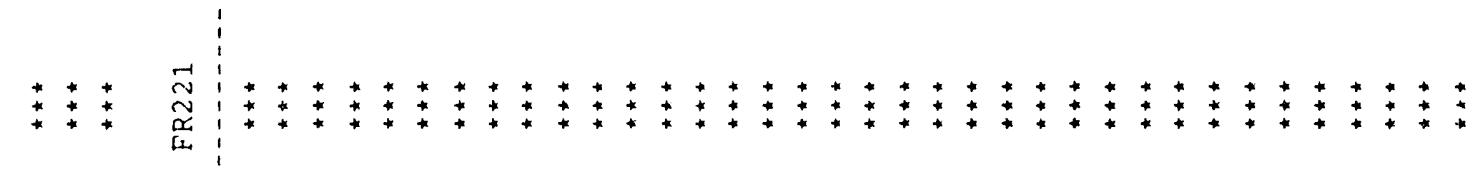

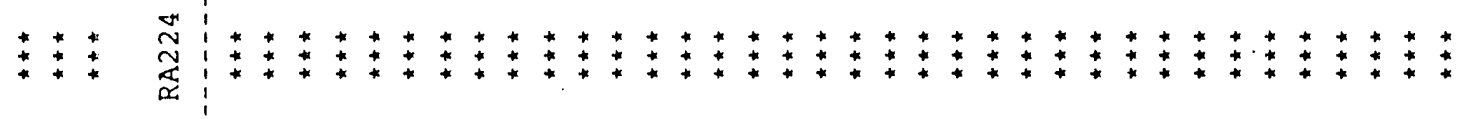

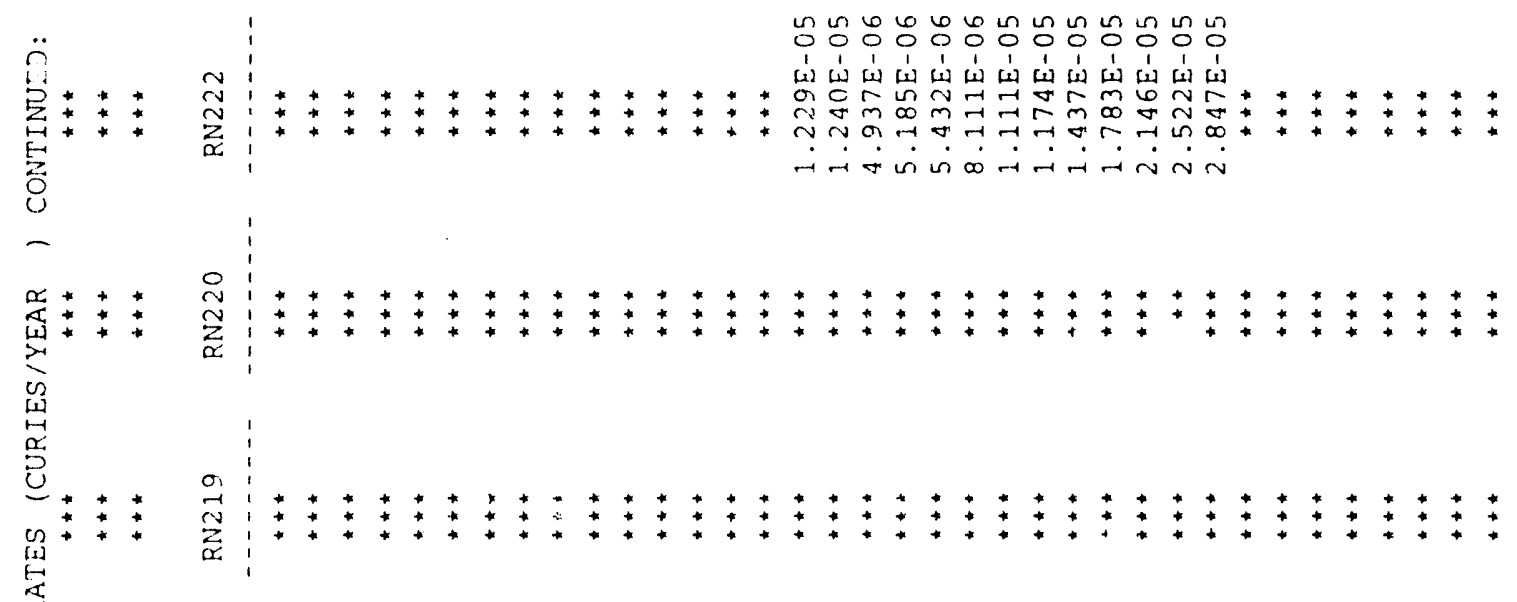
a 崖 


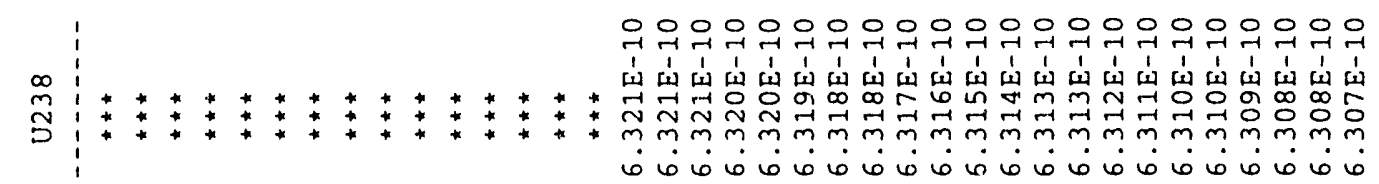

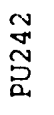

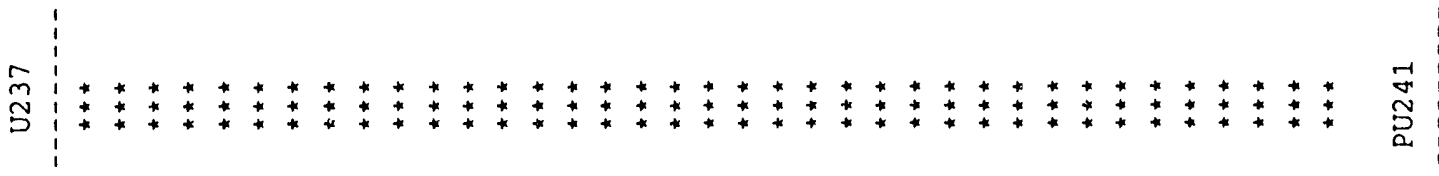

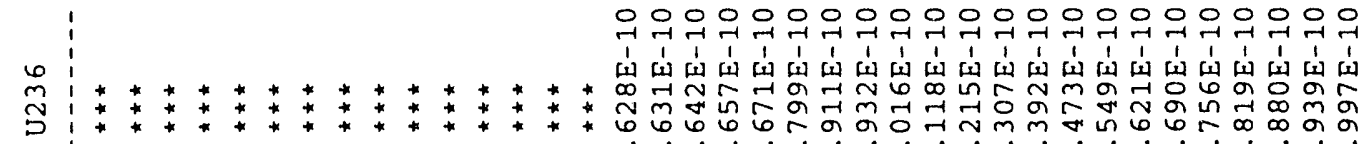

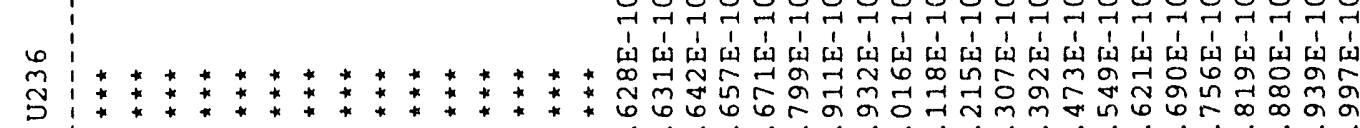

in

号

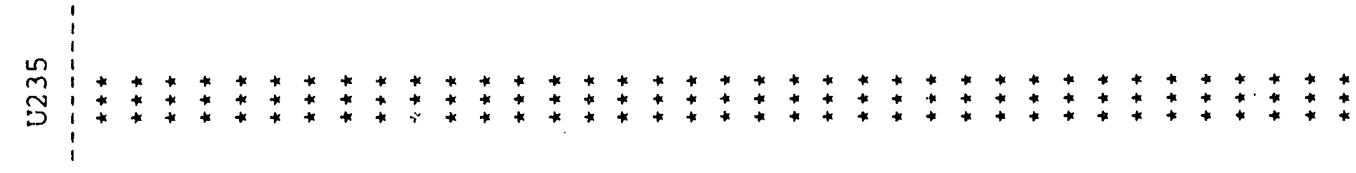

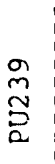

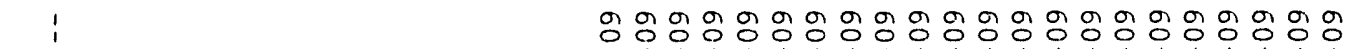

苟

$\dot{\sigma} \dot{\sigma} \dot{\sigma} \dot{\sigma} \dot{\sigma} \dot{\sigma} \dot{\sigma} \dot{\sigma} \dot{\sigma} \dot{m} \dot{m} \dot{m} \dot{m} \dot{m} \dot{m} \dot{m} \dot{m} \dot{m}$

$\stackrel{\infty}{\stackrel{\infty}{S}}$

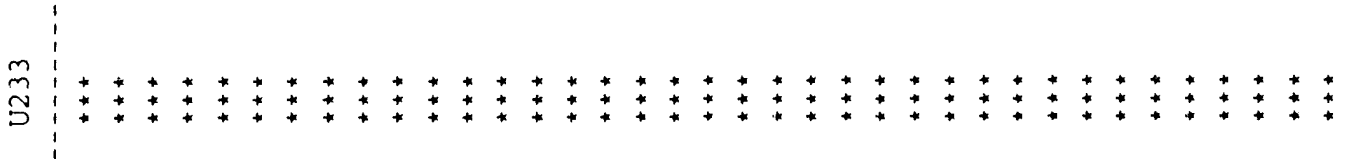

$\stackrel{m}{\stackrel{m}{2}}$

焉

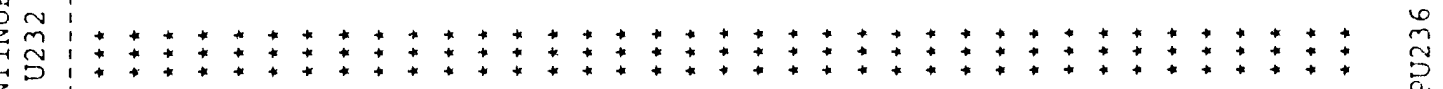

-

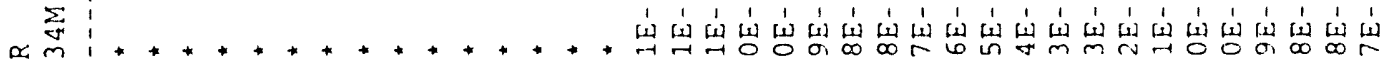

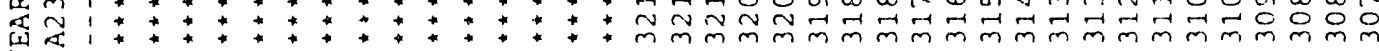

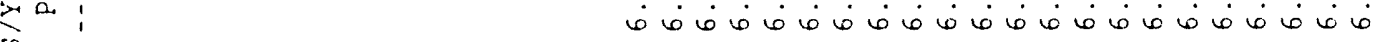

$\stackrel{2}{2}$

$\dot{-1}$

它

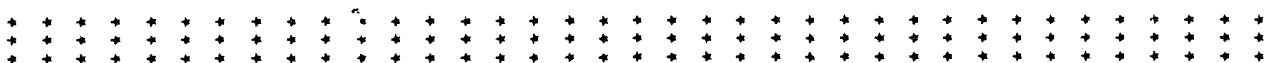

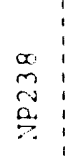
I

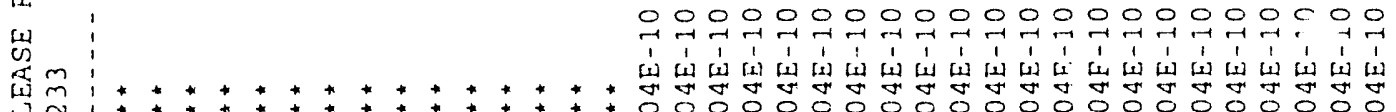

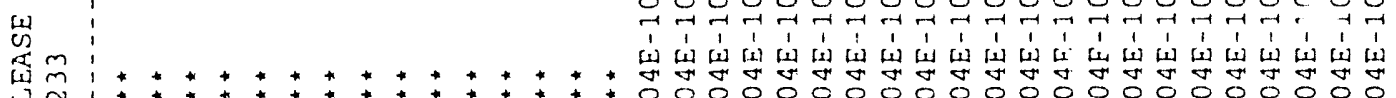

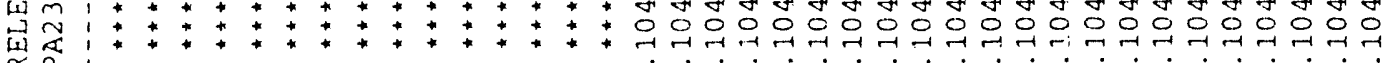
政

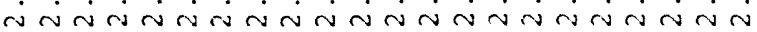

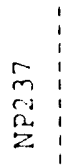

염 


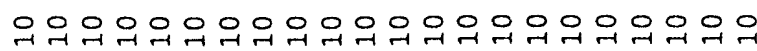

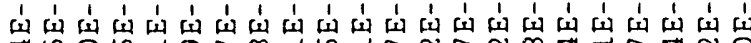

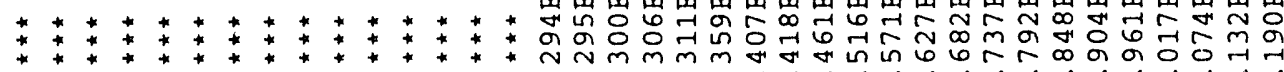
$\dot{\sim} \dot{\sim} \dot{\sim} \dot{\sim} \dot{N} \dot{N} \dot{N} \dot{N} \dot{N} \dot{N} \dot{N} \dot{\sim} \dot{m} \dot{m}$

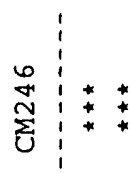

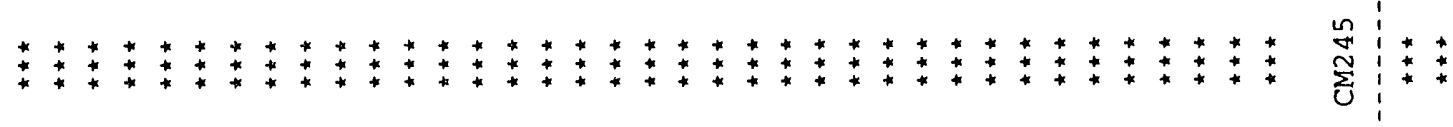

車

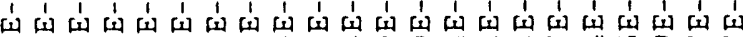
तू

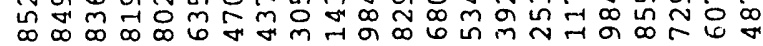
ती

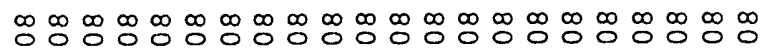

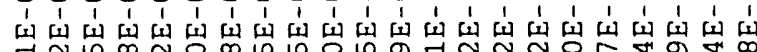

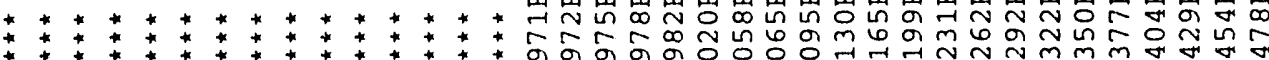

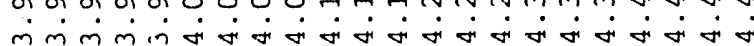

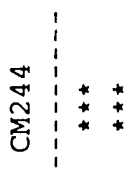

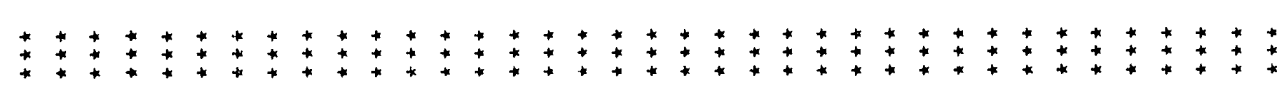

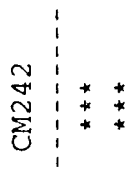

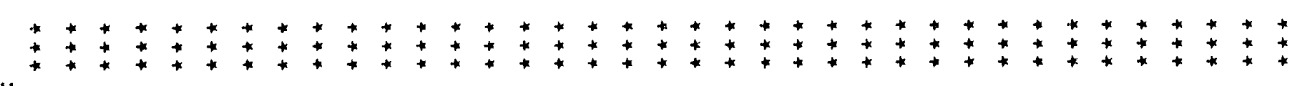
吕总

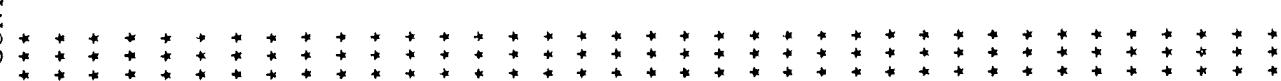

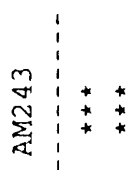
$-$

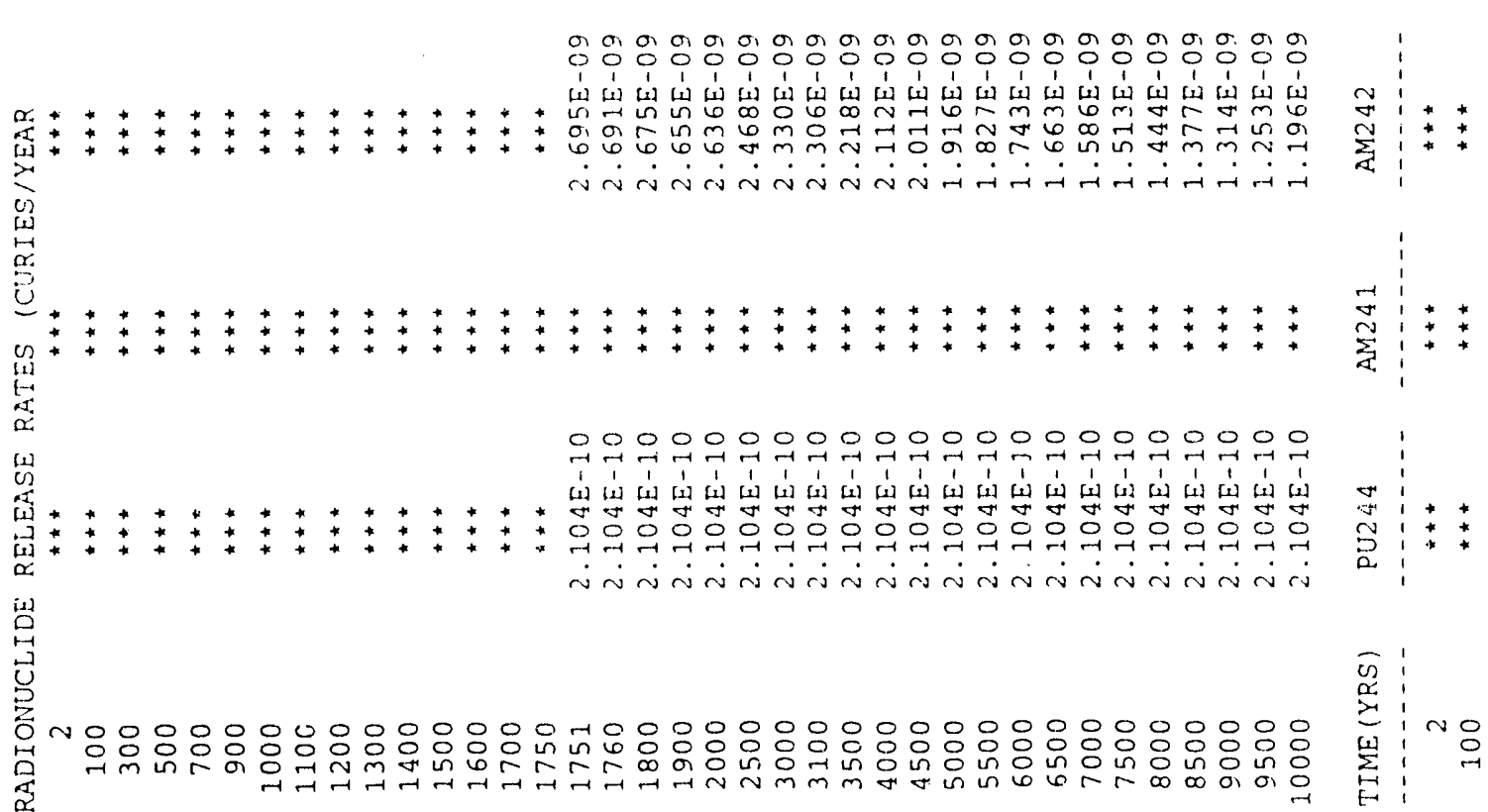




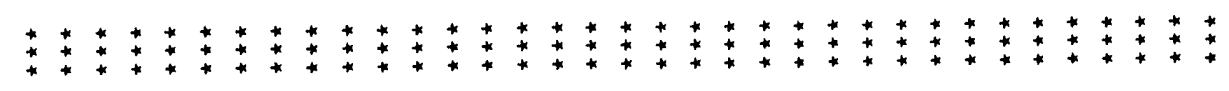

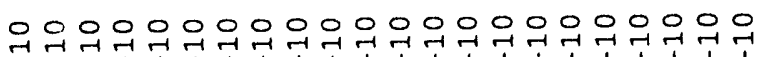

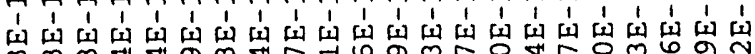

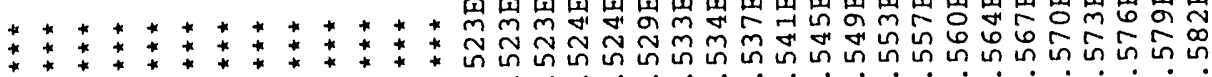

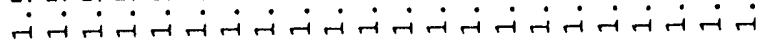
$\hat{\sim}$ \&

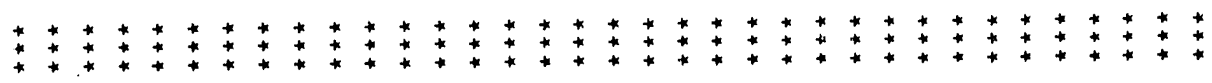

*

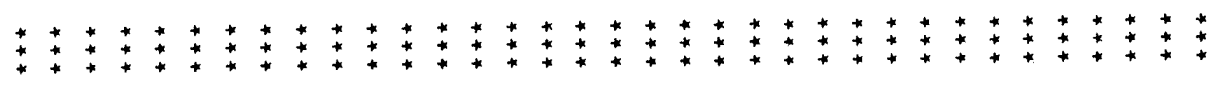

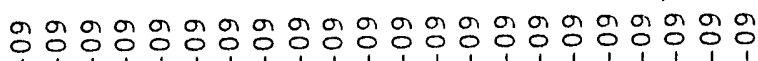

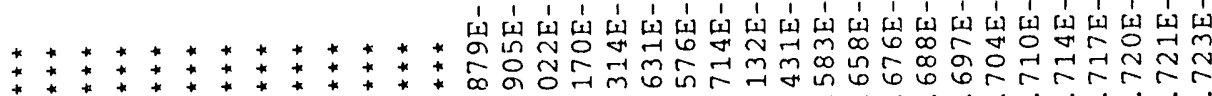

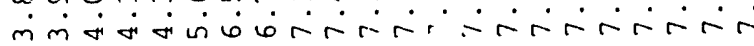

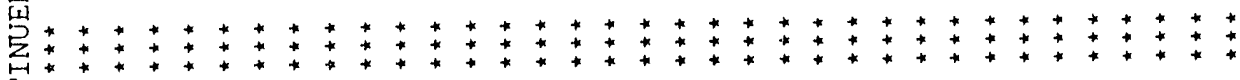
至

$-$

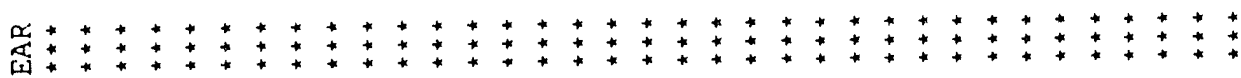

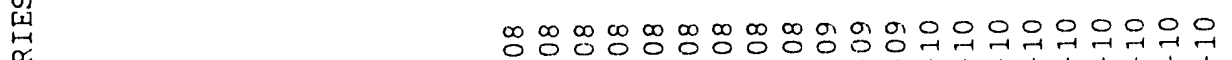
己

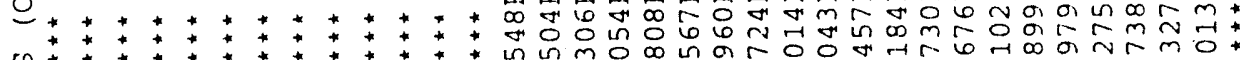
崫***********

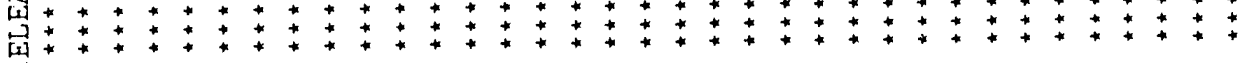
(1)

岑

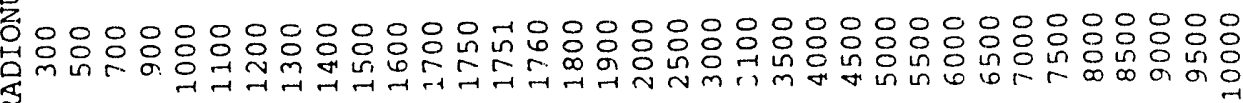

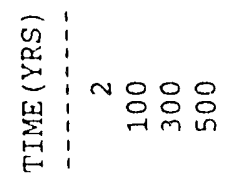




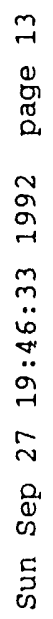

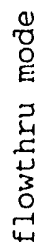

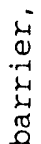

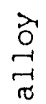

$\stackrel{\sim}{\infty}$

is

总是

a -

$\stackrel{\sim}{\sim}$

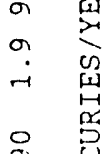

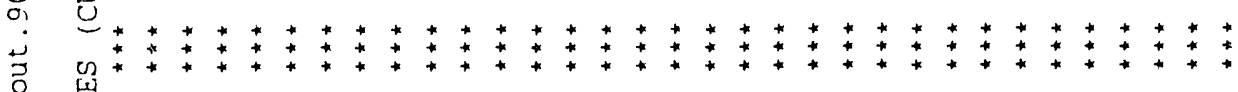

$\underset{\alpha}{\alpha}$

以

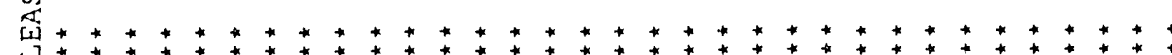

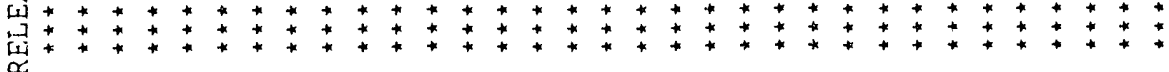

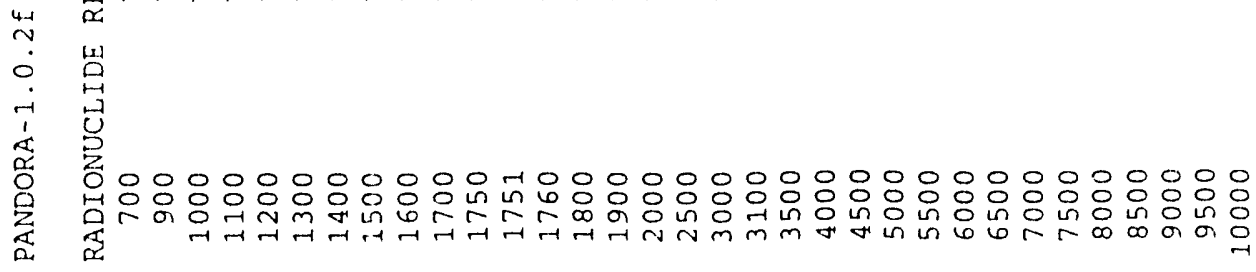




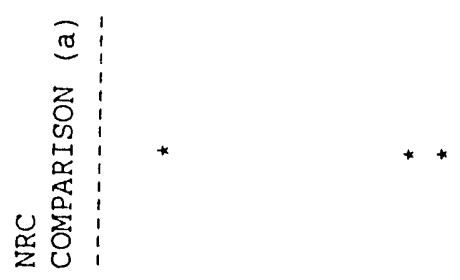

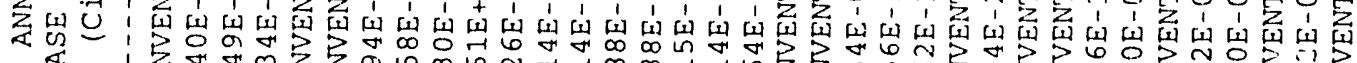

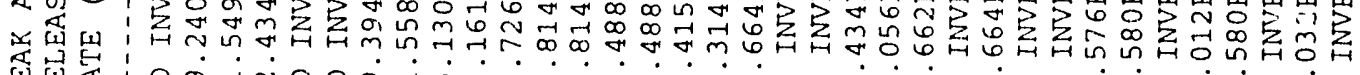

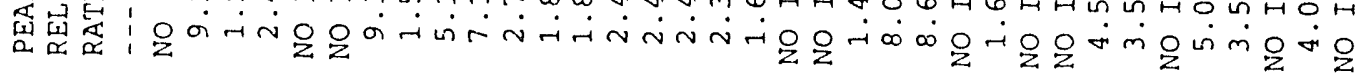




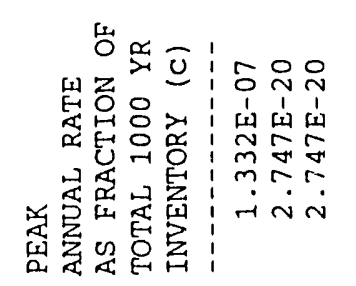

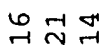

南尚它

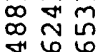

$\dot{i} \dot{\sim} \dot{r}$

용요 웅

फ的的

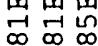

每.

$\dot{\infty} \dot{\infty} \dot{\mathrm{N}}$ 运它出开

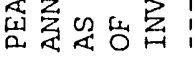
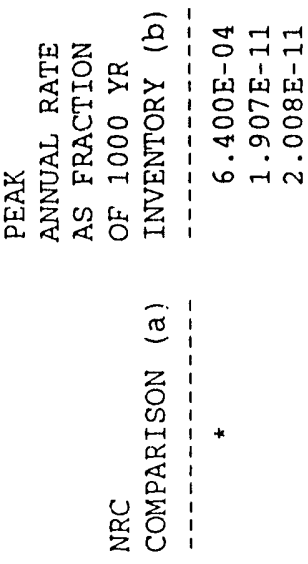

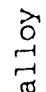

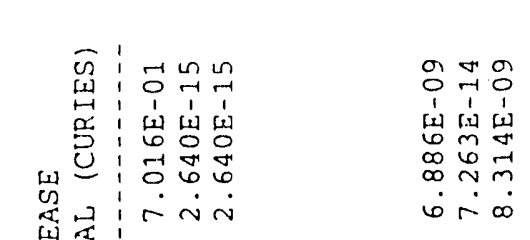
क्षित $\dot{0} \div \dot{\infty}$

出吉: 舅

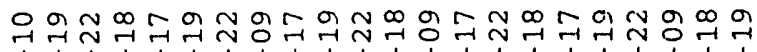

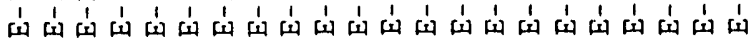
क्ष

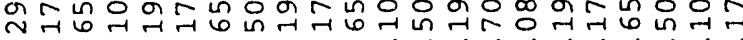

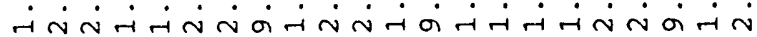

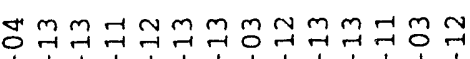

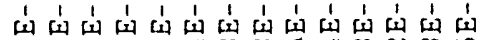

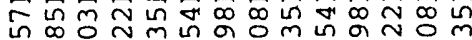

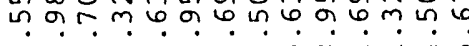

$\exists ㅋ \ni ㅋ ㅋ$

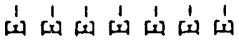
N

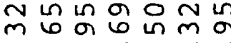

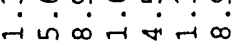

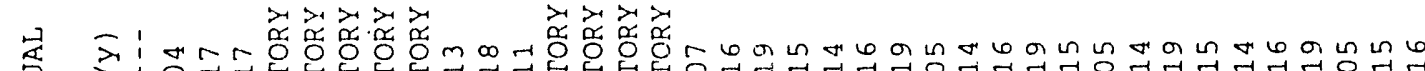
类

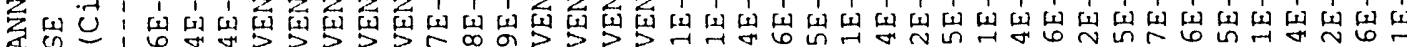

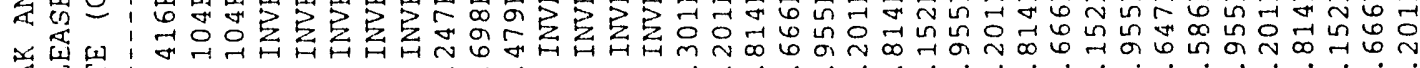

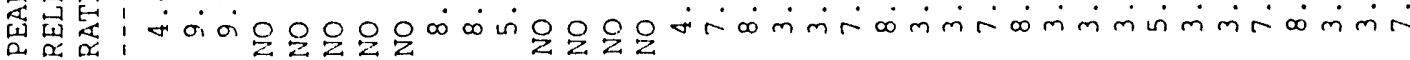

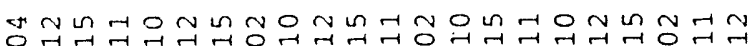

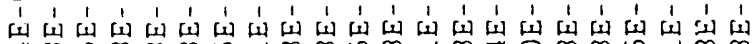

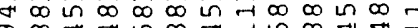

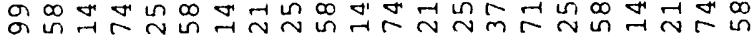
ம் n

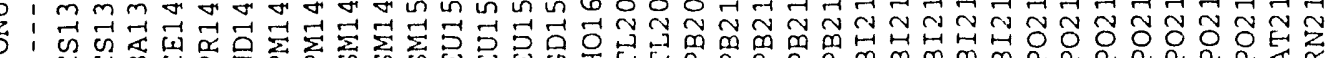




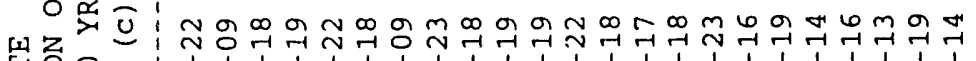

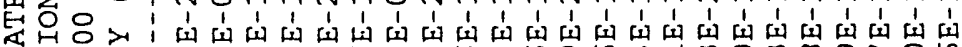

य웡 on

낙

यद्य

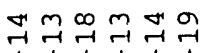

由ी

Nक्ष ने न잉요

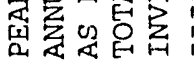

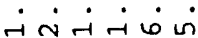

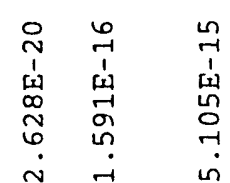

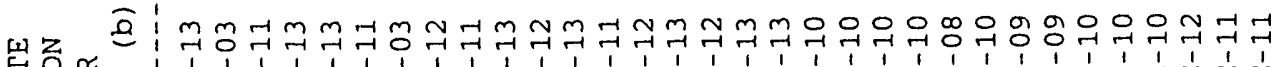

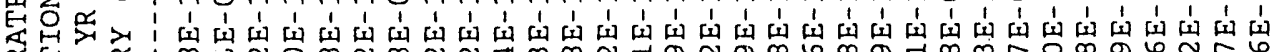

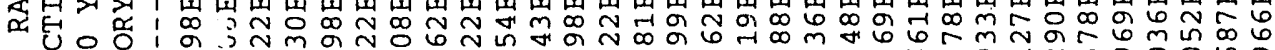

定起员悬

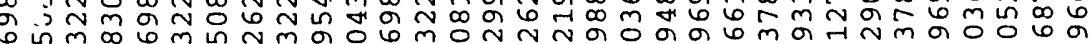

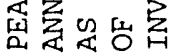

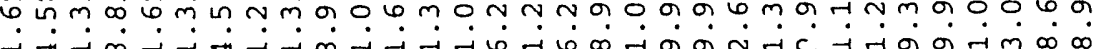

Fનન્ન

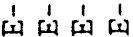

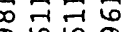
कृ mí

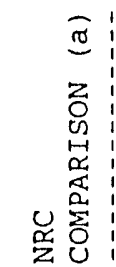

घ9

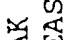

건 w 崖,

邑点

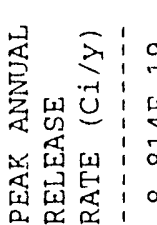

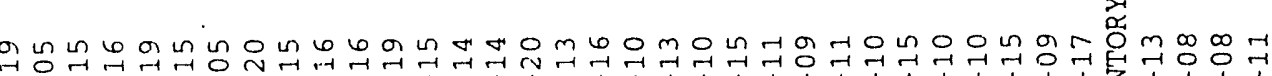

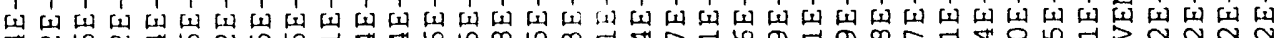

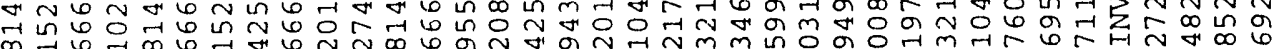
击岕运

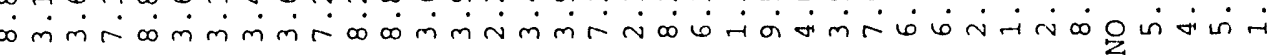

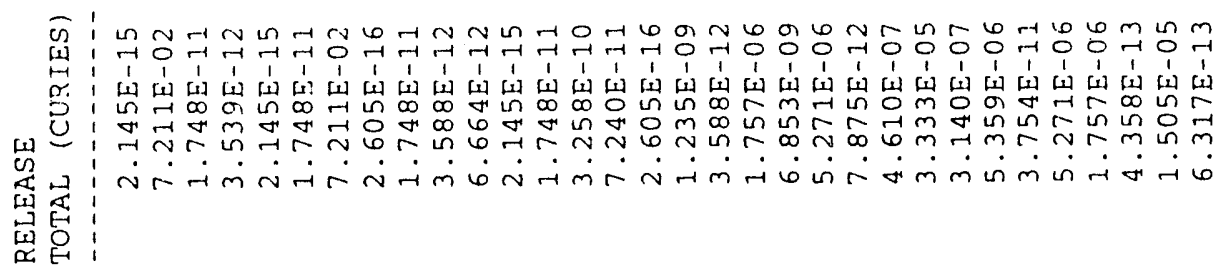

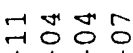

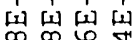
in $\rightarrow \sim r-1$ $\because+\infty$.

w

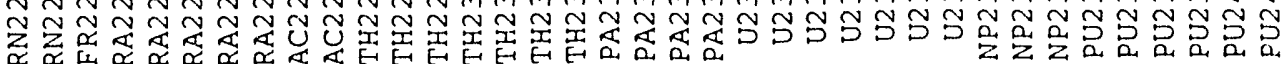




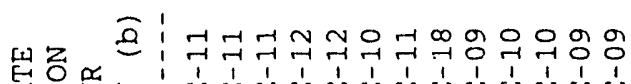

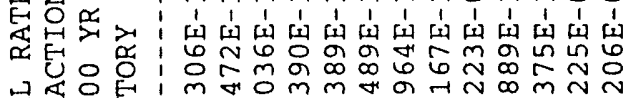

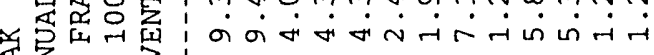

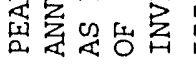

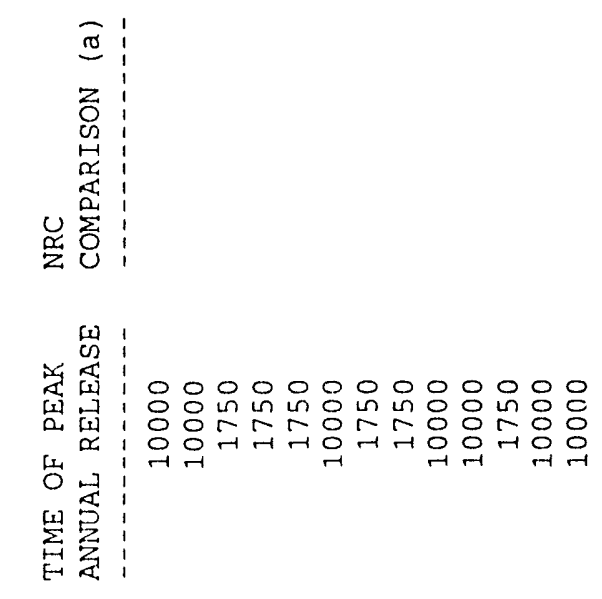

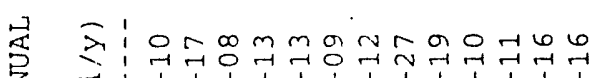

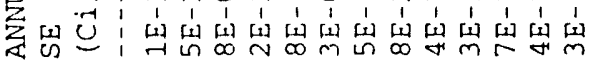
我 舀豈宠

⿹\zh26灬ำ

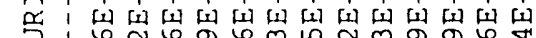

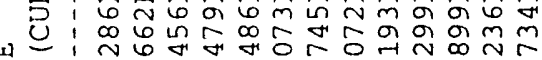
岁 空搌

㟧员

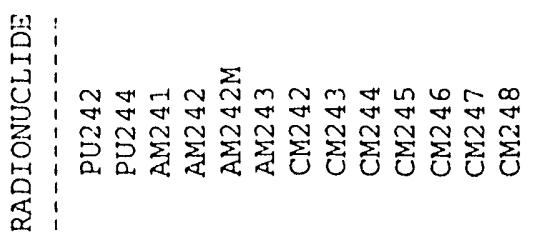




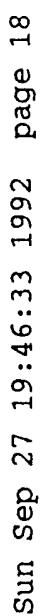

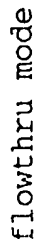

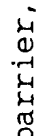

它

व

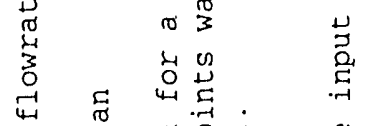

$\stackrel{\overrightarrow{0}}{\vec{\nexists}}$

담

范

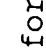

0
0
0
0

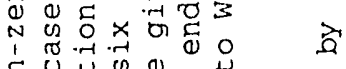

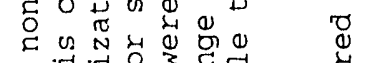

- $\begin{aligned} & -7 \\ & -7\end{aligned}$

is

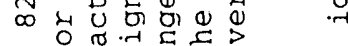

㟧

5.

मे थ

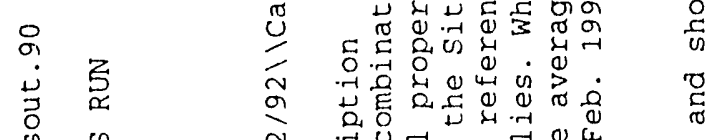

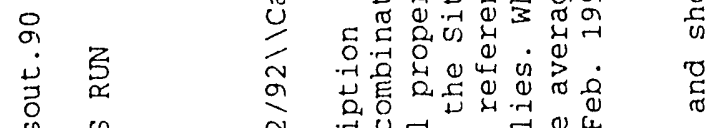

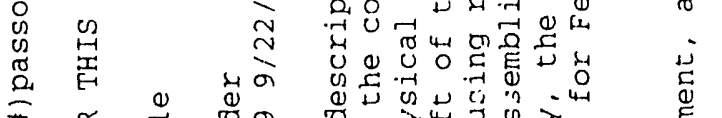

\#

出究出

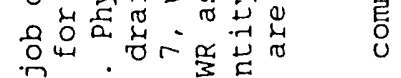

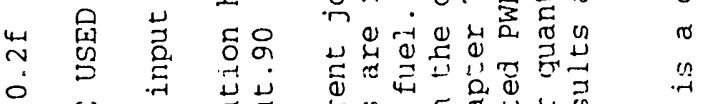

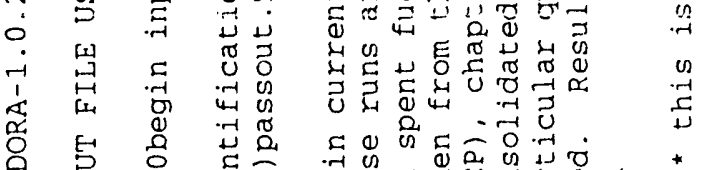

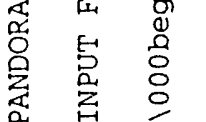

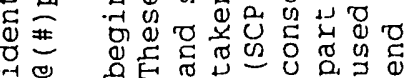

: 


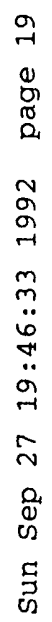

엉

这

它

$\stackrel{n}{\infty}$

芩

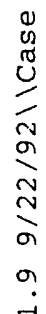

ने

욤

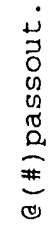

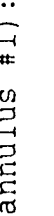

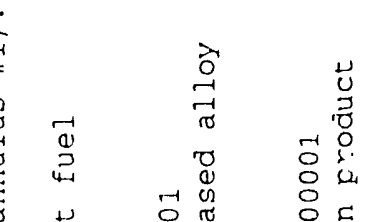

음
음

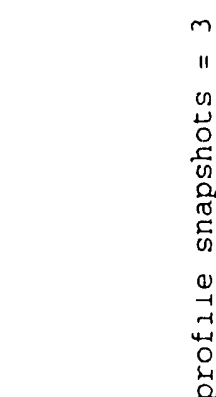

0
0

0

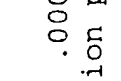

$\stackrel{\pi}{\mathbb{N}}$

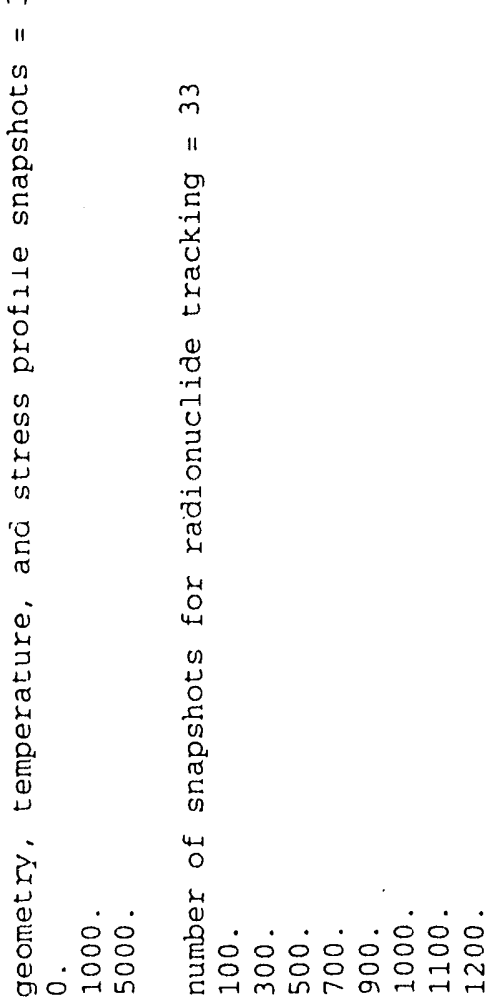




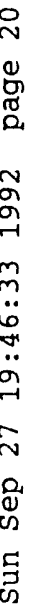

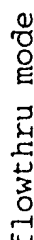

章

วั)

$\stackrel{\sim}{\infty}$

芩

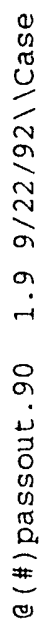

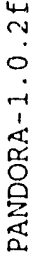

-

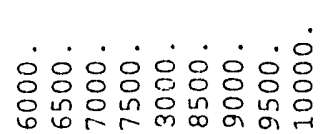

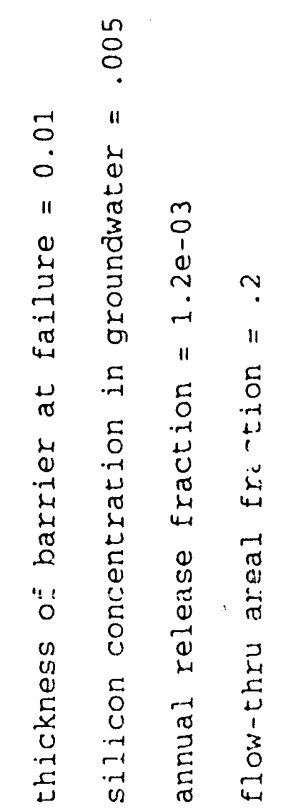

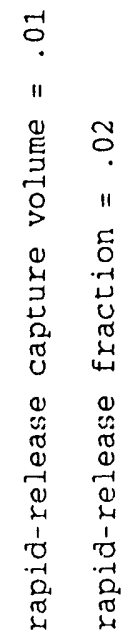

?

"

0
0
0
0
0
3
0
0
0 
$\vec{a}$
0
0
0
0
0
0
0
0
0
0
0
0
0
0
0
0
0
0
0
0

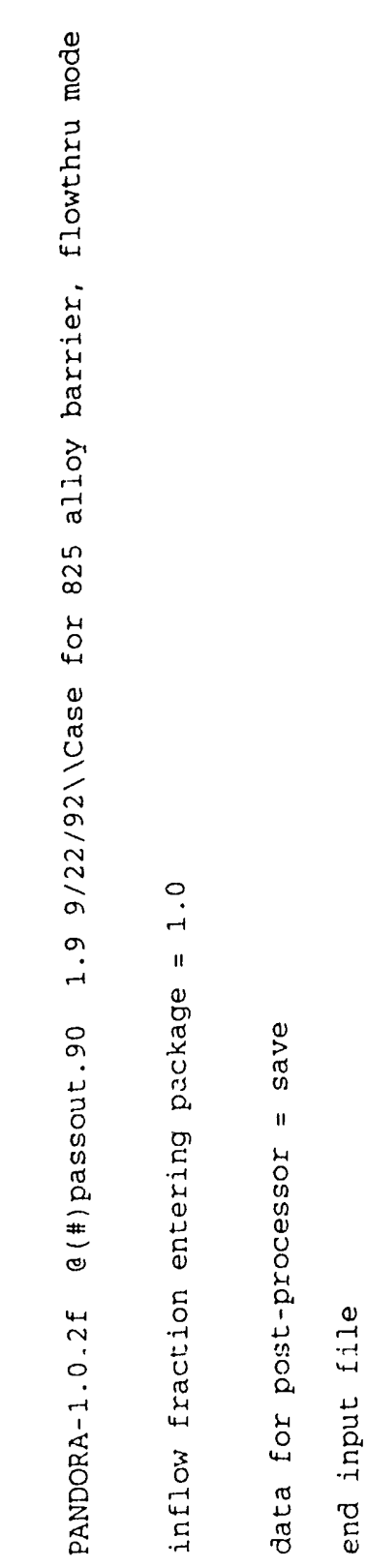

END DATE

$$
12-01-93
$$

